\title{
WRI $46-73$
}

$$
P B-241225
$$

FEASIBILITY OF DIGITAL WATER-QUALITY MODELING ILLUSTRATED BY APPLICATION AT BARSTOW, CALIFORNIA

S. G. Robson

Geological Survey

Menlo Park, California

February 1974

DISTRIBUTED BY:

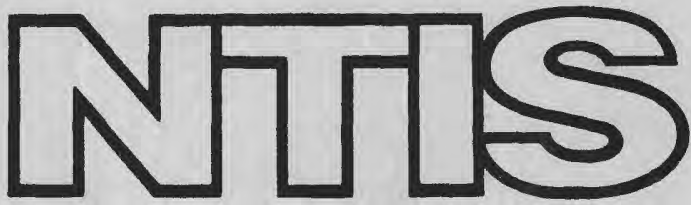

National Technical Information Service

U. S. DEPARTMENT OF COMMERCE 


\begin{tabular}{|c|c|c|}
\hline $\begin{array}{l}\text { BIBLIOGRAPHIC D́ATA } \\
\text { SHEET }\end{array}$ & \begin{tabular}{|ll|l} 
1. Report No. & USGS/WRD-75/020 \\
\end{tabular} & 3 \\
\hline \multirow{2}{*}{\multicolumn{2}{|c|}{$\begin{array}{l}\text { 4. Title and Subtitle } \\
\text { FEASIBILITY OF DIGITAL WATER-QUALITY MODELING ILLUSTRATED } \\
\text { BY APPLICATION AT BARSTOW, CALIFORNIA }\end{array}$}} & $\begin{array}{l}\text { 5. Report Date } \\
\text { February } 1974\end{array}$ \\
\hline & & 6. \\
\hline \multicolumn{2}{|l|}{$\begin{array}{l}\text { 7. Author(s) } \\
\text { S. G. Robson }\end{array}$} & $\begin{array}{l}\text { 8. Performing Organization Rept. } \\
\text { No. USGS/WRI-46-73 }\end{array}$ \\
\hline \multirow{2}{*}{\multicolumn{2}{|c|}{$\begin{array}{l}\text { 9. Performing Otganization Name and Address } \\
\text { U.S Geological Survey, WRD } \\
\text { California District } \\
345 \text { Middlefield Road } \\
\text { Menlo Park, California } 94025 \\
\end{array}$}} & 10. Project/Task/Work Unit No. \\
\hline & & 11. Contract/Grant No. \\
\hline \multicolumn{2}{|c|}{ 12. Sponsoring Organization Name and Address } & $\begin{array}{l}\text { 13. Type of Report \& Period } \\
\text { Covered } \\
\text { Final report } \\
\text { 14. }\end{array}$ \\
\hline
\end{tabular}

15. Supplementary Notes

16. Abstracts A digital water-quality model of the shallow alluvial aquifer near Barstow was evaluated to determine the applicability of the model computer program to varied hydrologic problems. The evaluation was made on the basis of the data requirements of the model, the characteristics and limitations of the model computer program, the relevance of the model results, and the computer costs associated with the model. Two-well tracer-dilution tests may not be a workable means of determining the aquifer dispersivity and porosity for use in a water-quality model. Such tests may not be necessary if a water-quality model with a large grid interval is under consideration because of the relative insensitivity of such a model to dispersivity. The model results were relevant to the real-life head and water-quality conditions in the aquifer near Barstow and provided an excellent means of evaluating the cause and effect relations associated with ground-water pollution.

17. Key Words and Document Analysis. 17a. Descriptors

*Model studies, *Ground water, *Feasibility studies, *Chemical degradation, California

17b. Identifiers/Open-Ended Terms

Barstow, Water-quality modeling, Ground-water quality management, Ground-water quality degradation Reproduced by NATIONAL TECHNICAL INFORMATION SERVICE US Depertment of Commeree 17c. COSATI Field/Group $\emptyset 4 \mathrm{~B}$ Springfield, VA. 22151

18. Availability Statement No restriction on distribution.

\section{PRICES SUBJECT TO CHANGE}

19. Security Class (This T21. No. of Pages Report)

UNCLASSIEIEP

20. Security Class (This Page 
$\begin{array}{lllllllllllll} & \text { O } & \text { T } & \text { I } & \mathbf{C} & \mathbf{E}\end{array}$

THIS DOCUMENT HAS BEEN REPRODUCED FROM THE BEST COPY FURNISHED US BY THE SPONSORING AGENCY. ALTHOUGH IT IS RECOGNIZED THAT CER. TAIN PORTIONS ARE ILLEGIBLE, IT IS BEING RE LEASED IN THE INTEREST OF MAKING AVAILABLE AS MUCH INFORMATION AS POSSIBLE。 
FEASIBILITY OF DIGITAL WATER-QUALITY

MODELING ILLUSTRATED BY APPLICATION

AT BARSTOW, CALIFORNIA

By S. G. Robson

U.S. GEOLOGICAL SURVEY

Water-Resources Investigations 46-73

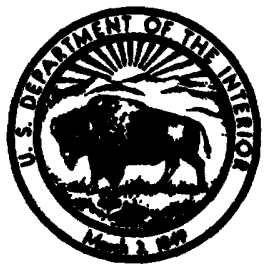

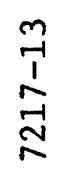

February 1974

ie 
UNITED STATES DEPARTMENT OF THE INTERIOR

Rogers C. B. Morton, Secretary

GEOLOGICAL SURVEY

V. E. McKelvey, Director

For additional information write to:

District Chief

Water Resources Division

U.S. Geological Survey

345 Middlefield Road

Menlo Park, Calif. 94025 


\section{CONTENTS}

\section{ILLUSTRATIONS}

Abstract-

Introduction-_-

Wel1-numbering system--

Location and geohydrologic setting

Modeling procedure--

Mode1 parameters-

Saturated thickness, transmissivity, and storage-coefficient data-

Quantity and quality of recharge and discharge-m-

Historic data on head and water quality-

Dispersivity--

Water-quality modeling--difficulties and limitations---- - - - - -

Model output-m-n

Model cost--

Conclusions-

Selected references-

Appendix: Steady-state water-quality model program--

Figure 1. Index map of study area-

2. Map showing generalized geology and well locations, Mojave River basin near Barstow- 8

3. Grid and recharge and discharge nodes of water-quality mode1- 10

4. Map showing steady-state saturated thickness of the younger alluvial aquifer- 12

5. Map showing transmissivity-_ 13

6. Comparison of historic water-level hydrographs and model-generated water-level hydrographs-_- 18

7. Comparison of historic water-quality hydrographs and model-generated water-quality hydrographs- 19

8. Map showing model-generated steady-state water-1evel contours- 20

9. Map showing water quality for 1945 based on modified

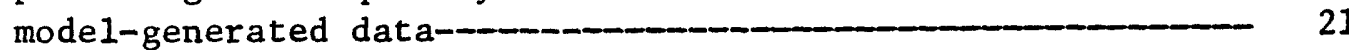

10. Photographs showing equipment used in tracer-dilution test--- 23 
Figures 11-13. Graphs showing:

11. Tracer-breakthrough curves for tracer-dilution test--

12. Tracer-breakthrough curve for tracer-dilution test near Tucson, Ariz- 24

13. Model-generated tracer-breakthrough curve----- 27

14. Model-generated concentration profiles along column 9 of water-quality model after 6 years of recharge

from upper Barstow sewage ponds-

15. Variation in mode1-generated concentration profiles with time along column 11 in a water-quality model of part of Coachella Valley, Calif

16. Model-generated concentration profile along column 4 in a small-scale model after 24 hours of

injection-well recharge-

17. Diagram showing idealized cross section of the Waterman fault--

18. Diagrammatic profile of dissolved-solids concentration, March 1972, along the Mojave River

19-30. Maps showing:

19. Model-generated 1971 dissolved-solids concentration, without historic recharge from lower Barstow sewage ponds, with historic recharge from U.S. Marine Corps

20. Molf course and sewage ponds-concentration without historic recharge from U.S. Marine Corps golf course, with historic recharge from lower Barstow sewage ponds and U.S. Marine Corps sewage ponds----

21. Model-generated 1971 dissolved-solids concentration, with historic recharge from lower Barstow sewage ponds and U.S. Marine Corps golf course and sewage ponds-_-_-

22. Model-generated contours for dissolved-solics concentration of 400 milligrams per liter in plume of degraded water below upper Barstow sewage ponds between 1946 and 1969--

23. Estimated 1972 dissolved-solids concentration-

24. Model-generated 1981 dissolved-solids concentration, run 55

25. Mode:-generated 1991 dissolved-solids concentration, run 55- 40

26. Model-generated 1972-91 head changes, run 55m. 47

27. Model-generated 1972-91 head changes, run 58A-

28. Model-generated 1987 dissolved-solids concentration, run 61-....... 49

29. Model-generated 1991 dissolved-soiids concentration, run 61- 50

30. Model-generated 1972-91 head changes, run 61.... 51 
TABLES

Table 1. Recharge and discharge data for Barstow water-quality

Page mode1-

2. Driller's log of injection well at two-well tracer-dilution test site-_-_-_ 


\author{
FEASIBILITY OF DIGITAL WATER-QUALITY MODELING ILLUSTRATED BY \\ APPLICATION AT BARSTOW, CALIFORNIA
}

By S. G. Robson

\begin{abstract}
A digital water-quality model of the shallow alluvial aquifer near Barstow was evaluated to determine the applicability of the model computer program to varied hydrologic problems. The evaluation was made on the basis of the data requirements of the model, the characteristics and limitations of the model computer program, the relevance of the model results, and the computer costs associated with the model.

Two-well tracer-dilution tests may not be a workable means of determining the aquifer dispersivity and porosity for use in a water-quality model. Such tests may not be necessary if a water-quality model with a large grid interval is under consideration because of the relative insensitivity of such a mode1 to these parameters. The water-quality model is not readily applicable to hydrologic conditions such as abrupt changes in aquifer saturated thickness or transmissivity. Model head declines that are large in relation to the saturated thickness of the aquifer can cause disruptions in water-quality calculations of the model. The model results were relevant to the real-life head and water-quality conditions in the aquifer near Barstow and provided an excellent means of evaluating the cause-and-effect relations associated with ground-water pollution. The cost of operating the water-quality model may be nominal if a small number of model nodes and a short simulation period can be used.
\end{abstract}




\section{INTRODUCTION}

Miscible displacement problems are of great economic importance in a society increasingly confronted by ground-water pollution. As a result, emphasis in water-resources research has been placed on development of mathematical methods that describe the two-dimensional movement and dispersion of contaminants in aquifers. Because of the complexity of the partial differential equations that describe this movement, numerical methods are commonly used in their solution. Garder, Peaceman, and Pozzi (1964) proposed the method of characteristics for treating the problem of two-dimensional transport and dispersion in porous media. Redde11 and Sunada (1970) subsequently modified the method of characteristics to consider the tensorial nature of dispersion in multidimensional flow and developed a two-dimensional water-quality model.

J. D. Bredehoeft applied the procedure of Reddell and Sunada in conjunction with a flow model that used an implicit alternating-direction iterative mathematical procedure (Pinder and Bredehoeft, 1968) to develop a two-dimensional water-quality model (Bredehoeft and Pinder, 1973). The model simulates the chemical and hydraulic response of a confined or unconfined aquifer to varying rates of withdrawal and recharge. Porosity and dispersion are considered in calculating the concentration of any chemically conservative constituent (for example, chloride, dissolved solids) at any point in the aquifer.

Although Bredehoeft and Pinder (1973) applied the model to a field problem at Brunswick, Ga., the model has not been thoroughly evaluated by application to other field problems. Thus, one objective of this study was to construct and verify a water-quality model of a ground-water basin for which documented ground-water degradation has occurred. The waterquality model provided a basis for evaluating the feasible applications of the model computer program and indicated problems that may be enconatered when water-quality modeling is undertaken in other areas.

The dispersivity of an aquifer may be estimated by running tracer dilution tests in wells or, in adequately documented areas, by a series $a r$ water-quality model runs. Therefore, a second objective was to conduct a two-well tracer test in the study area and to compare these results with the model-determined dispersivity. The availability of abundant basic. data on the nature and source of pollutants and the hydrologic characten... istics of the aquifer near Barstow, Calif., make this area ideal for constructing and evaluating á water-quality model. 
Construction of the water-quality model involved analysis of hydrologic data used in previous ground-water modeling of the Mojave River basin (Hardt, 1971) to determine the transmissivity, storage coefficient, pumpage, and quantities of inflow and outflow for the aquifers between Barstow and the Waterman fault. Additional refinements were made of the transmissivity and storage-coefficient data, based on aquifer tests run as part of ongoing studies in the area.

Data on the location, quantity, and quality of pollutants entering the aquifer, rates of movement, and areal extent of the plumes of degraded water were available and were supplemented by other ongoing studies in the area. These data, in addition to the dispersivity, were used in building the waterquality model.

The dispersivity was estimated by using the water-quality model to indicate the value that gave the best verification. The dispersivity was also determined in the field by use of two-well tracer-dilution tests in which a chemical tracer was injected into a well and an adjacent pumping well then was monitored to record the rate of movement and change in concentration of the tracer in the aquifer. The field determination of the dispersivity was then compared with the dispersivity indicated by the model to evaluate the feasibility of using tracer tests to estimate the dispersivity in other, less well documented aquifers.

To evaluate the applicability of the water-quality model:

1. The model parameters were examined to determine if the type, quantity, and accuracy of the data required to construct and verify the model were such that the model parameters could be defined without undue difficulty.

2. The characteristics and limitations of the computer program for the water-quality model and some of the assumptions made in water-quality modeling were examined to determine their effects on the applicability of the model.

3. The mode1-generated data were examined to determine if the model results would be of a useful form that could be easily related to hydraulic and water-quality problems existing in the field.

4. The cost of running the computer program for the water-quality model was examined to determine if cost would be a deterrent to use of the model.

The assistance of J. D. Bredehoeft, U.S. Geological Survey, Denver, Colo., who prepared the computer program and made valuable suggestions for the formulation of the model is gratefully acknowledged. In addition, the work of J. L. Hughes, U.S. Geological Survey, Garden Grove, Calif., and D. B. Grove, U.S. Ceological Survey, Denver, Colo., materially contributed to the completeness of this study. 


\section{We11-Numbering System}

Wells are assigned numbers according to their location in the rectangular system for the subdivision of public land. As shown by the diagram, the part of the number preceding the slash (as in $9 \mathrm{~N} / 1 \mathrm{~W}-9 \mathrm{~B} 1$ ) indicates the township (T. $9 \mathrm{~N}$.$) ; the part of the number between the slash and the hyphen indicates$ the range ( $R_{0} 1 \mathrm{~W}$.); the number following the hyphen indicates the section (sec. 9); the letter following the section number designates the 40-acre subdivision of the section. Within each 40-acre tract the wells are numbered serially as indicated by the final digit. Thus, well $9 \mathrm{~N} / 1 \mathrm{~W}-9 \mathrm{~B} 1$ is the first

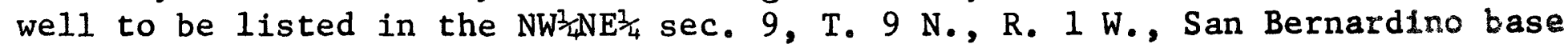
line and meridian.

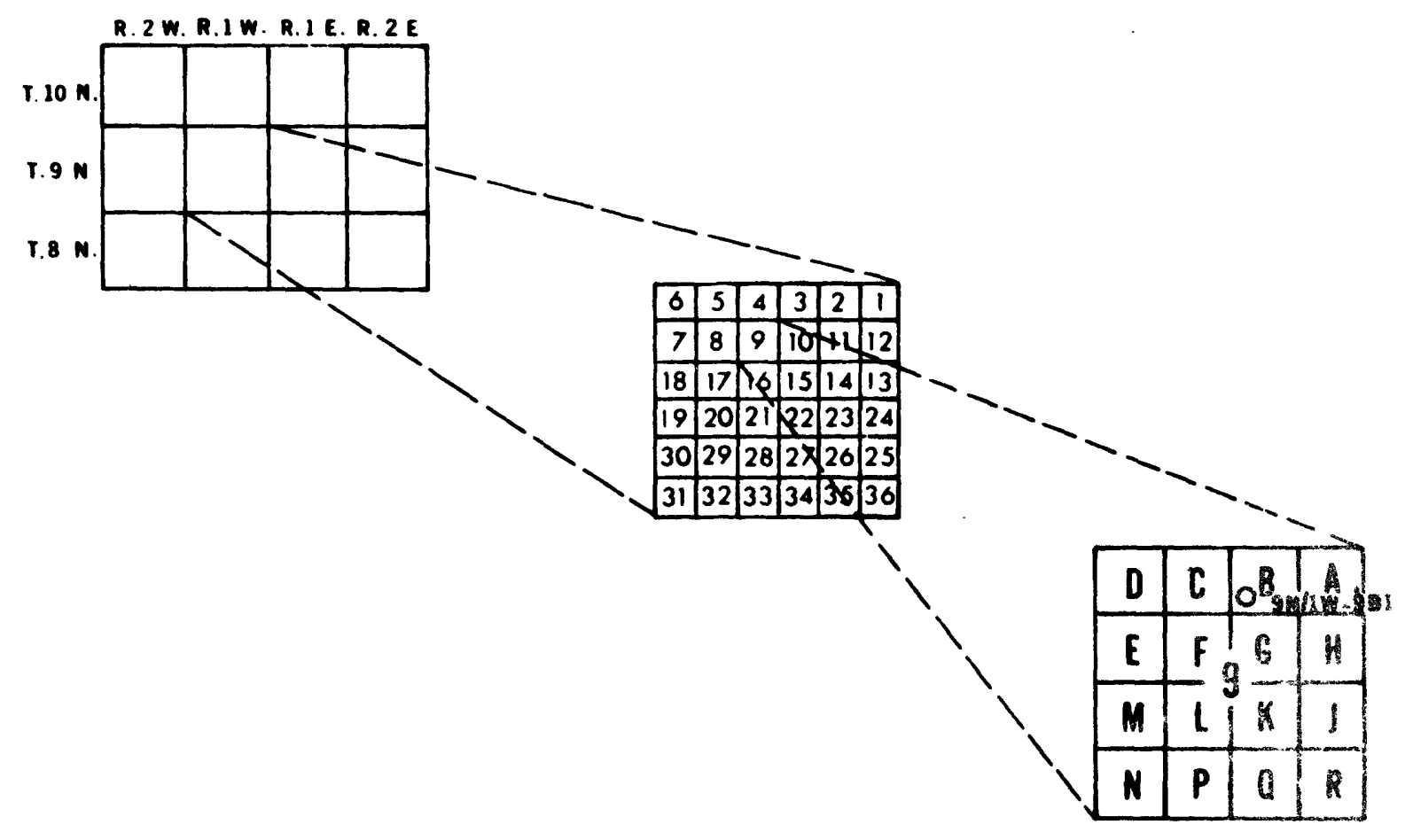

Location and Geohydrologic Setting

Barstow is 96 miles northeast of Los Angeles in the Mojave Desert region of southern California adjacent to the normally dry Mojave River (fig. 1). Precipitation averages about 5 inches per year and produces negligible ground-water recharge. Ground water in storage is the only reliable sour"e thater for the main water purveyors (the city of Barstow and the U.S. Karine Corps Supply (enter at Nebo). The quantity of ground water in storage is large in relation to the local demand and is of good chemical quality in areas not affected by serious degradation (Mili er, 1969). 


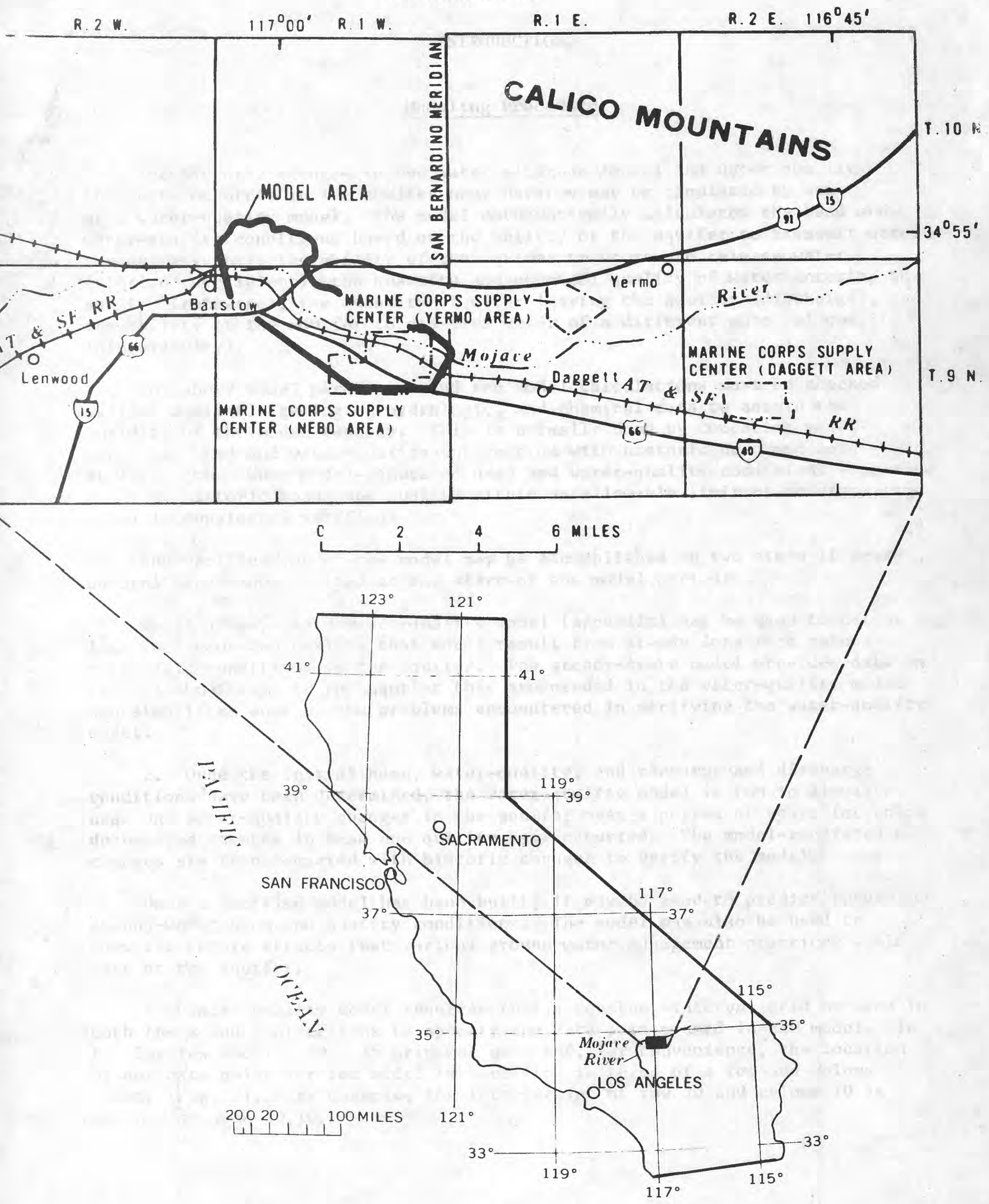

FIGURE 1.--Study area. 
The main aquifer near Barstow consists of very permeable younger alluvium of Holocene age deposited by the Mojave River and alluvial fans. The aquifer is underlain in some areas by much less permeable older alluvium, of Pleistocene age, and in other areas by consolidated rocks of Quaternary and Tertiary age that yield very little water to wells (fig. 2). The younger alluvial aquifer is about 1 mile wide and about 100 feet thick. Along the south side of the Mojave River the older alluvium underlies the younger alluvium. The older alluvium contains water of poorer chemical quality than that found in the younger alluvium, but the older unit is of relatively lower permeability and contributes only a fraction of the total recharge to the younger alluvial aquifer.

Water levels in the younger alluvial aquifer reflect the intermittent surface flow in the Mojave River. Steady ground-water-level declines in some areas exceed 40 feet during dry years when no surface flow occurs and may be followed by as much as 50 feet of recovery during a year with ample surface flow (Hardt, 1969, p. 9).

The chemical quality of water in the main aquifer east of Barstow has been deteriorating since 1951 (Miller, 1969, p. 37). The city of Barstow and the Atchison, Topeka and Santa Fe Railway Co. sewage-treatment ponds were located in the Mojave River north of Barstow prior to 1969 (upper Barstow sewage ponds in fig. 2). The ponds were adjacent to and upgradient from an area of degraded ground-water quality. In 1969 a new treatment plant designed to meet the cumbined needs of the city of Barstow and the railway company went into operation about 3 miles east of Barstow (lower Barstow sewage ponds in fig. 2). Treated effluent percolating from the new ponds is producing a second plume of degraded ground water. Both plumes have moved downgradient sufficiently to pose a threat to the watersupply wells at the U.S. Marine Corps (USMC) Supply Center at Nebo (written commun., J. L. Hughes, 1972).

In some areas ground-water contamination results from the deep percolation of irrigation water. The Marine Corps irrigates a 30-acre golf course with effluent from its sewage-treatment plant. This practice produces ground-water recharge of much poorer chemical quality than would occur if fresh water were used for irrigation. The resulting plume of degraded water may already extend into some of the Marine Corps supply wells (written commun., J. L. Hughes, 1972). Several minor plumes of degraded ground water exist along the north side of the Mojave River where about 150 acres of alfalfa are irrigated. 


\section{Modeling Procedure}

The historic changes in the water altitude (head) and water quality that have occurred in the aquifer near Barstow may be simulated by use of a water-quality model. The model mathematically calculates the head and water-quality conditions based on the ability of the aquifer to transmit water (transmissivity), the ability of the aquifer to store and release water

(storage coefficient), the quantity and chemical quality of water entering the aquifer (recharge), the quantity of water leaving the aquifer (discharge), and the ability of the aquifer to disperse water of a different chemical quality (dispersivity).

The above model parameters and the model calculations must be checked against available geologic, hydrologic, and chemical data to assure the valifity of the model results. This is normally done by comparing modelgenerated head and water-quality information with historic head and waterquality data. When model-generated head and water-quality conditions approximate the historic heads and quality within an allowable limit of accuracy, the model is considered verified.

The verification of the model may be accomplished in two steps if nearnatural conditions existed at the start of the model period:

1. A steady-state water-quality model (appendix) may be used to calculate the heads and quality that would result from steady long-term natural hydrologic conditions in the aquifer. The steady-state model provides data on initial conditions in the aquifer that are needed in the water-quality model and simplifies some of the problems encountered in verifying the water-quality model.

2. Once the initial head, water-quality, and recharge and discharge conditions have been determined, the water-quality model is run to simulate head and water-quality changes in the aquifer over a period of years for which documented changes in head and quality have occurred. The mode1-generated changes are then compared with historic changes to verify the model.

Once a verified model has been built, it may be used to predict future ground-water head and quality conditions. The model may also be used to show the future effects that various ground-water management practices would have on the aquifer.

The water-quality model requires that a constant-interval grid be used in both the $\mathrm{x}$ and $\mathrm{y}$ directions to specify the data points used in the model. In the Barstow model a 38 × 15 grid was used and, for convenience, the location of any data point for the model is specified in terms of a row and column number (fig. 3). For example, the intersection of row 20 and column 10 is defined as node 20,10 . 


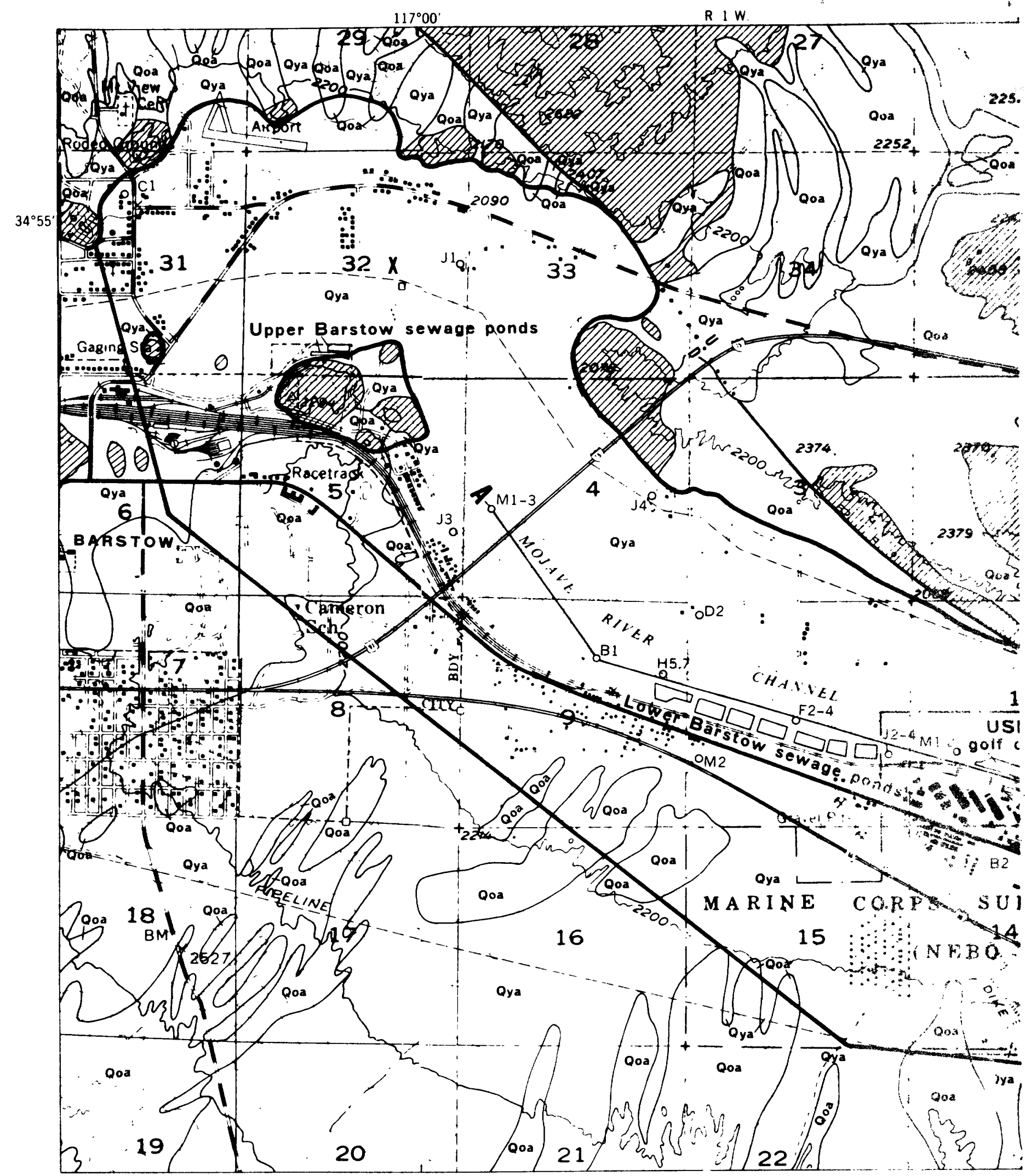

Base from U S Geological Survey

Barstow. 1956. and Daggett. 1 ys6

$117^{\circ} 00^{\circ}$

162.500 Highways as of 1972 


\section{INTRODUCTION}

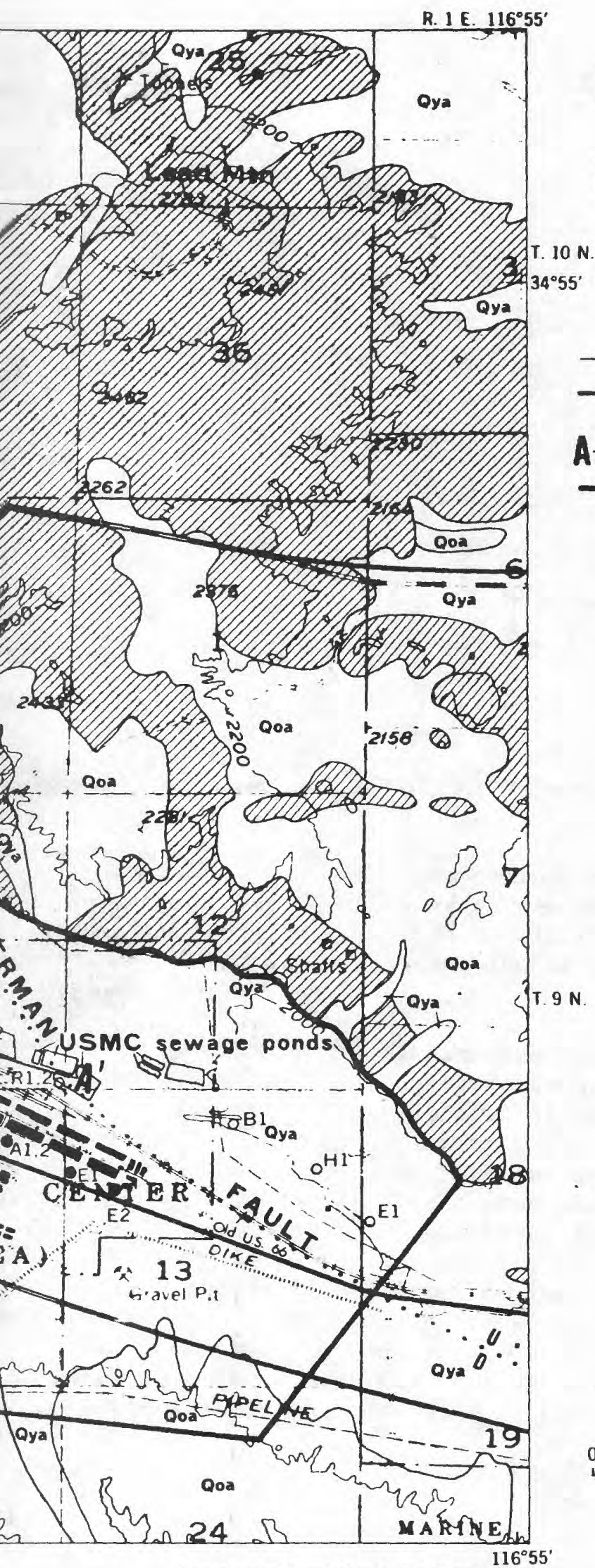

Geology modified after G. A. Miller (1969)

\section{EXPLANATION}

\section{9}

Qya YOUNGER ALLUVIUM OF HOLOCENE AGE-Gravel to clay in grain size; unit consists of unconsolidated river-channel deposits and locally derived fan deposits; where saturated yields large quantities of water to wells

Qoa OLDER ALLUVIUM OF PLEISTOCENE AGE-Unconsolidated to moderately consolidated; boulder gravel to clay in grain size; where saturated yields small to moderate quantities of water to wells

UNDIFFERENTIATED CONSOLIDATED ROCKS OF QUATERNARY AND TERTIARY AGE - Basalt, conglomerate, sandstone. siltstone, shale, limestone, tuff, and quartz monzonite; yields little water to welis

\section{CONTACT}

U. FAULT_Dotted where concealed; $U$, relatively upthrown block, $D$, relatively downthrown block

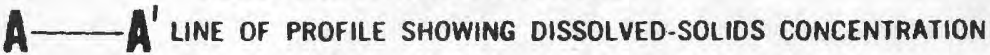
MODEL BOUNDARY

$X$ tracer-dilution test site

OJ1 WELL AND NUMBER

B2 USMC SUPPLY WELL AND NUMBER

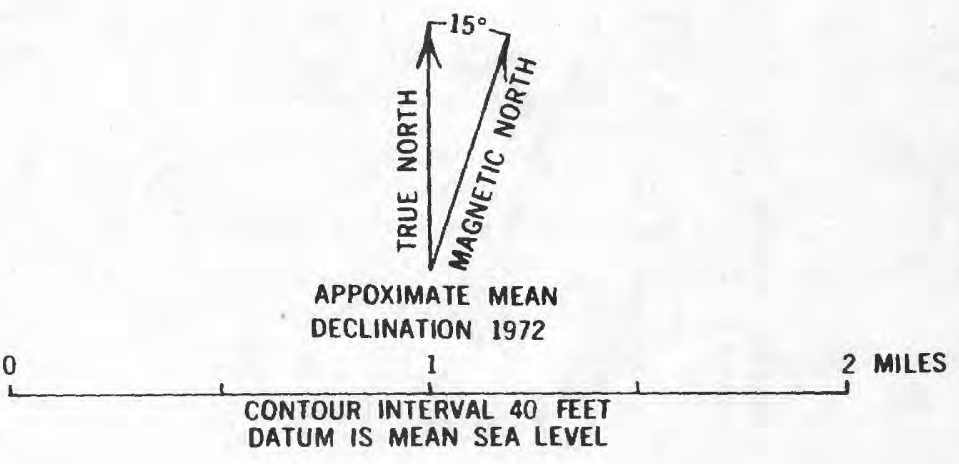



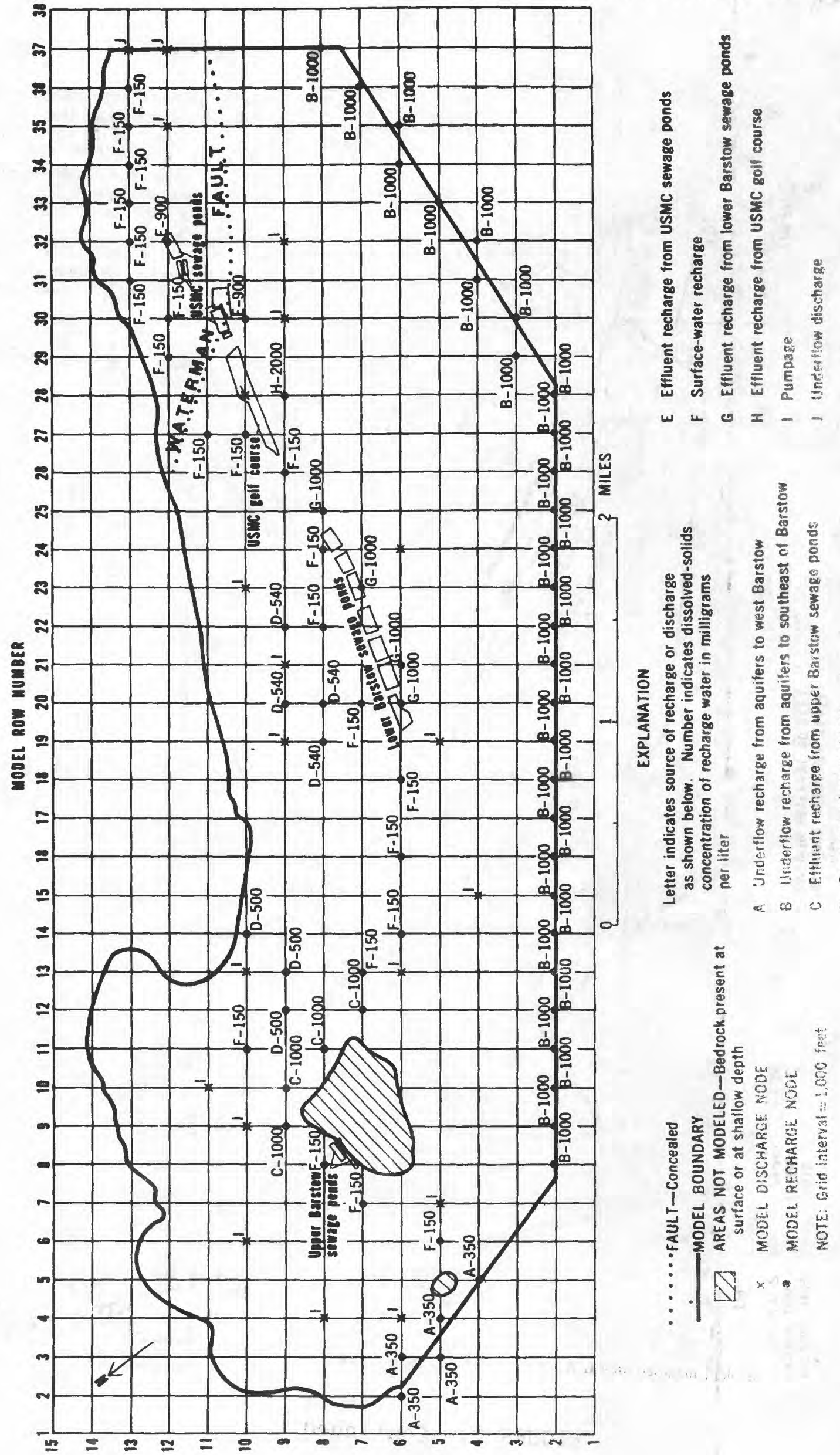
MODEL PARAMETERS

\section{Saturated Thickness, Transmissivity, and Storage-Coefficient Data}

The data used in (1) the Barstow water-quality model and (2) the steadystate model are briefly discussed in order to illustrate the type of data needed to construct the models and to provide an initial basis for evaluation.

If a water-table aquifer is present, as in the Barstow area, a map of the saturated thickness of the aquifer at the start of the model period is required for the water-quality model. These data are not required for the steady-state model. About 130 wells were used to determine the 1946 saturated thickness of the younger alluvial aquifer (fig. 4). Because no wells fully pentirate the older alluvium south of the Mojave River, a saturated thickness of 100 feet was assumed for this aquifer. Both aquifers were assumed to function as a unit, and a single-layer model was used.

A map of the transmissivity (saturated thickness times hydraulic conductivity) of the aquifer at the start of the model period is needed for both the water-quality model and the steady-state model (fig. 5). The map can be constructed either based on transmissivity $(T)$ calculated directly from aquizer tests or derived from specific-capacity tests. It can also be based on hydraulic conductivity (derived from aquifer or specific-capacity tests) times saturated thickness estimated from drillers' logs and water-level maps. The latter technique was used for the Barstow model because the spatial variations in saturated thickness are better defined than are the spatial variations in $\mathrm{T}$.

Hydraulic conductivities calculated from tests on wells in the younger alluvium averaged about 150 feet per day (1,100 gallons per day per square foot), and tests on wells in the older alluvium outside the model area indicated a hydraulic conductivity of about 1.5 feet per day (10 gallons per day per square foot).

The Waterman fault crosses the model area and acts as a barrier to the movement of ground water. Available data indicate that the barrier effect of the fault may begin about 15 feet below land surface in the riverbed and becoire increasingly effective with greater depth. Under steady-state conditions, heads were near land surface in alluvium of the riverbed, and the upper, highly permeable part of the alluvium at the fault was saturated. To simulate these conditions an average fault $T$ of about 9,400 feet squared per day $(70,000$ gallons per day per foot) was used in the steady-state model. As heads near the fault decline, the fault becomes a more effective barrier. In the vater-quality model an average fault $T$ of 200 feet squared per day ( 1,500 gallons per day per foot) was used to simulate the effects of the fault. The same $T$ data were used in the water-quality model and the steadystate model, with the exception of the transmissivity of the Waterman fault. 


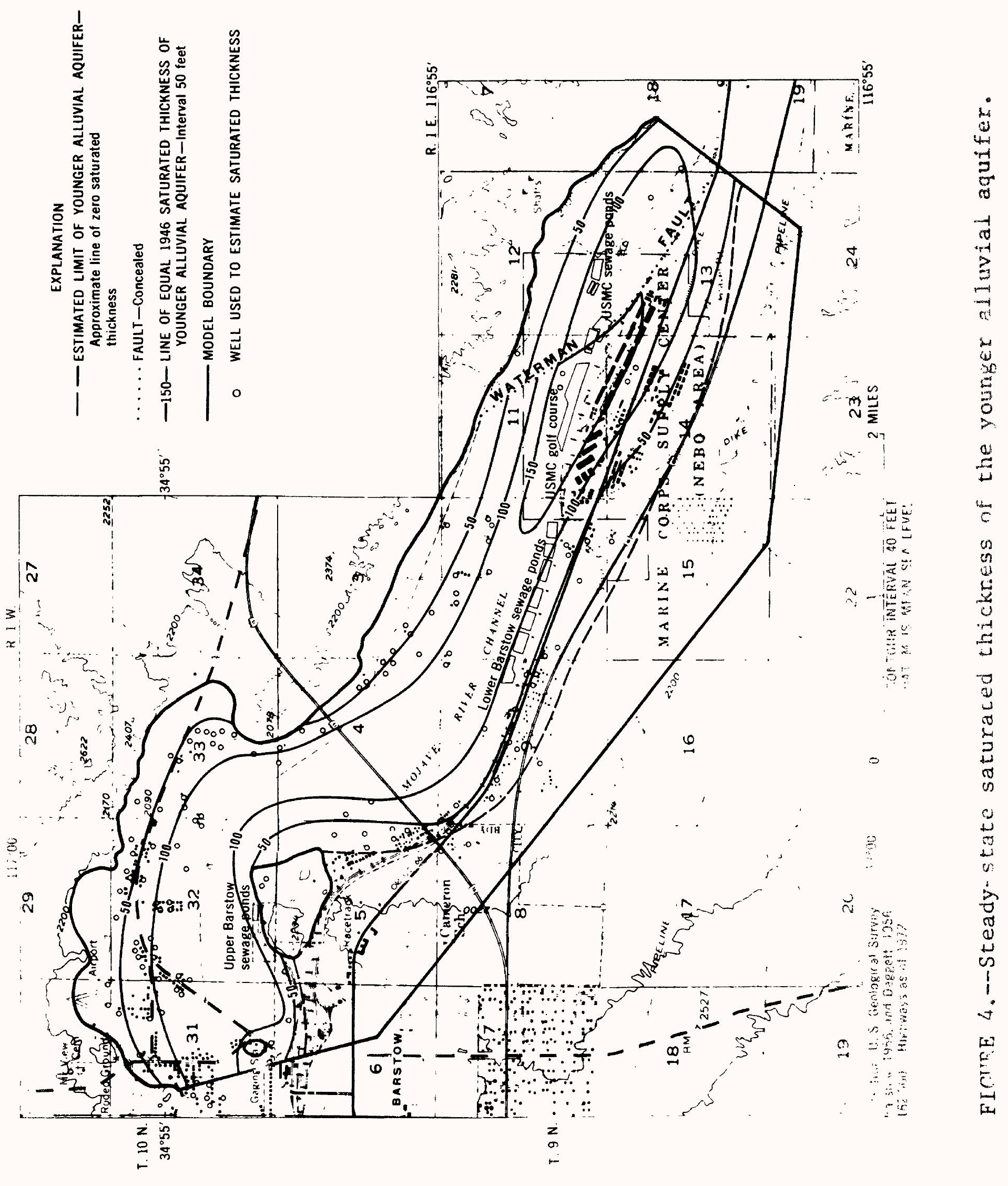




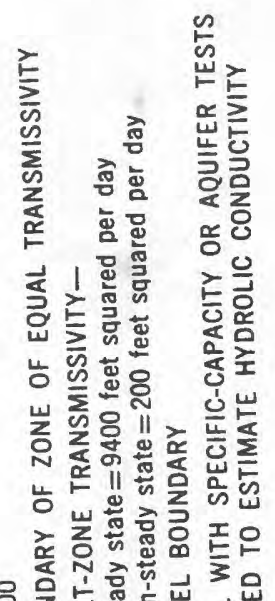

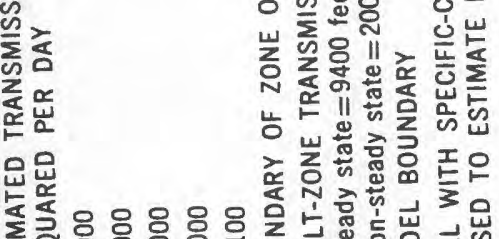

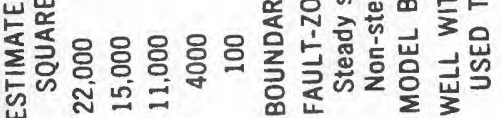

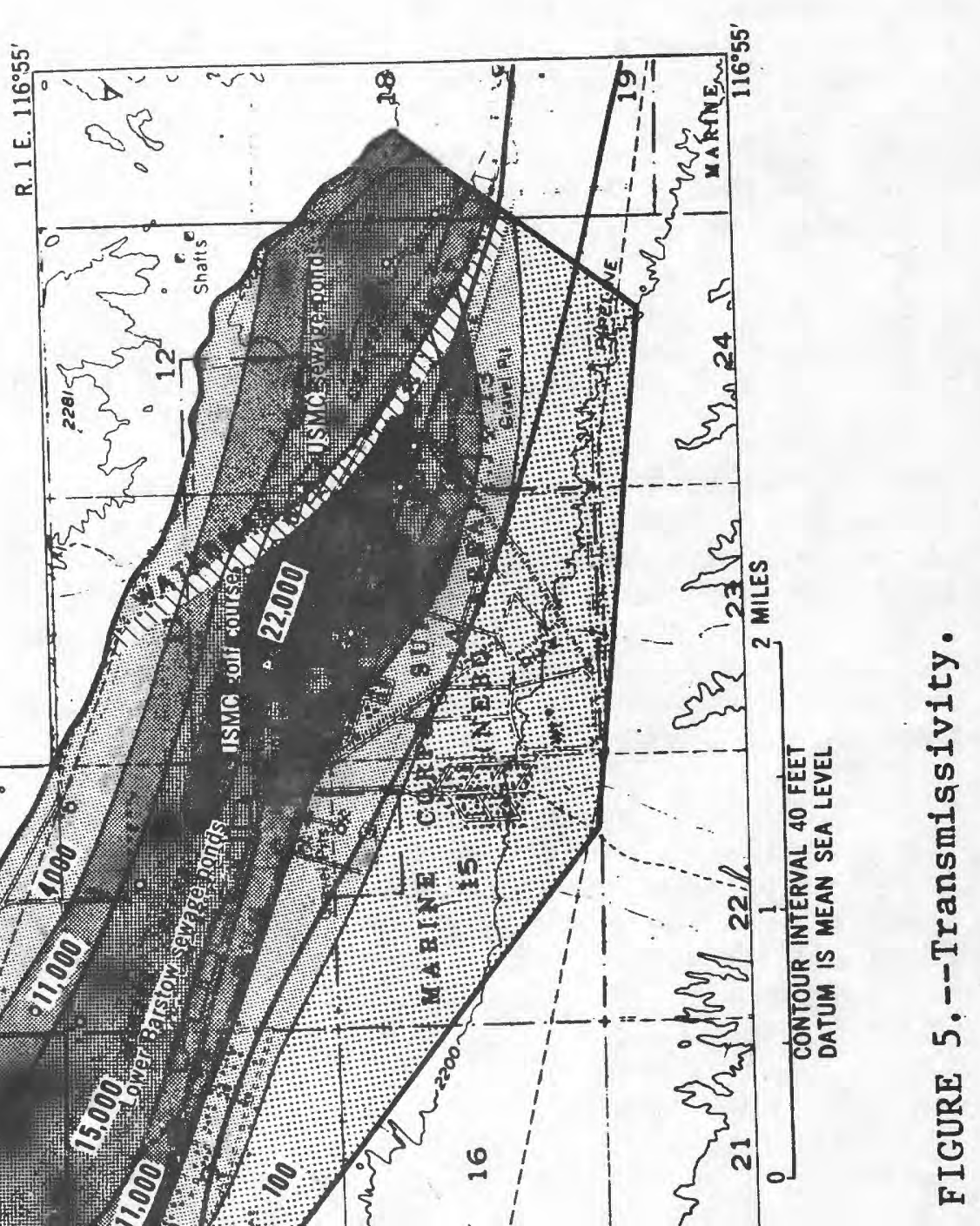


The data used to construct the map of the specific yield of the aquifer were of lesser reliability than other data used in the model. Specific yield data based on laboratory analysis of undisturbed core samples (Hardt, 1971) and data from an extensive aquifer test of a well in the model area (written commun., J. L. Hughes, 1972) indicate that the specific yield is about 20 percent in the younger alluvial aquifer and about 12 percent in the older alluvial aquifer. In areas where the aquifers locally intertongue, a specific yield of 16 percent was assumed. The model was run to determine how much the coefficient could be varied without producing a significant effect on the model-generated heads. It was found that a 50-percent increase in the specific yield produced significant variations in the model-generated heads, and that a 20-percent increase produced variations that were detectable but were within acceptable limits.

\section{Quantity and Quality of Recharge and Discharge}

The water-quality model was used to simulate the ground-water conditions during the 26-year period from 1946 to 1971 for purposes of verification. All recharge and discharge data were divided into seven pulses of varied length to form a step function that approximates the variations in these data over the 26-year period (table 1 ). The recharge and discharge data used in the Barstow model were divided into the following categories: underflow recharge, surface-water recharge, effluent recharge, underflow discharge, pumpage, and pumpage-return recharge.

Underflow recharge is the subsurface inflow to the model aquifers from the aquifers west of Barstow and from the much less permeable aquifer southeast of Barstow. Variations in this quantity of recharge represent changes in inflow due to changes in saturated thickness of the aquifers west of Barstow (table 1). The aquifer southeast of Barstow is undeveloped and has undergone very little change in head.

Surface water is recharged to the model area from streamflow in the Mojave River. Most of the recharge occurred as a result of floods in 1952 , 1958, and 1969. This is the major source of recharge to the aquifer and is the main factor that determined the distribution and length of the rechargedischarge pulses used in the model. The quantities of surface-water recharge shown in table 1 were uniformly distributed among the surface-water rechargt nodes shown in figure 3. The greater concentration of surface-water recharge nodes northeast of the Waterman fault (fig. 3) reflects the increased ability of the aquifer to accept recharge in this area. This increased recharge potential is due to the large volume of unsaturated alluvium associated with the drop in head across the Waterman fault. 
TABLE 1.--Recharge and discharge data for Barstow water-quality model

[See figure 3 for location of nodes]

\begin{tabular}{|c|c|c|c|c|c|c|c|}
\hline \multirow{2}{*}{$\begin{array}{r}\text { Node or } \\
\text { location } \\
\end{array}$} & \multicolumn{7}{|c|}{ Recharge or discharge pulses, in acre-feet per year } \\
\hline & $1946-51$ & 1952 & $1953-57$ & 1958 & $1959-68$ & 1969 & $1970-71$ \\
\hline \multicolumn{8}{|l|}{ Underflow recharge } \\
\hline From west & 1,100 & 1,100 & 1,100 & 1,100 & 800 & 800 & 800 \\
\hline From southeast & 120 & 120 & 120 & 120 & 120 & 120 & 120 \\
\hline Surface-water recharge & 350 & 7,400 & 0 & 9,900 & 260 & 20,000 & 0 \\
\hline \multicolumn{8}{|l|}{ Effluent recharge } \\
\hline Upper Barstow sewage ponds & 550 & 640 & 750 & 860 & 1,200 & 0 & 0 \\
\hline Lower Barstow sewage ponds & 0 & 0 & 0 & 0 & 0 & 3,000 & 1,800 \\
\hline USMC sewage ponds & 410 & 410 & 460 & 610 & 350 & 380 & 480 \\
\hline USMC golf course & 0 & 0 & 0 & 0 & 150 & 150 & 150 \\
\hline Underflow discharge & 590 & 630 & 360 & 490 & 490 & 700 & 420 \\
\hline \multicolumn{8}{|l|}{ Model pumpage } \\
\hline 4,6 & 330 & 370 & 230 & 230 & 570 & 650 & 740 \\
\hline 4,8 & 34 & 52 & 70 & 70 & 78 & 56 & 63 \\
\hline 6,10 & 40 & 41 & 42 & 40 & 74 & 0 & 170 \\
\hline 7,5 & 0 & 2 & 440 & 520 & 44 & 0 & 0 \\
\hline 9,10 & 100 & 110 & 57 & 92 & 10 & 7 & 1 \\
\hline 10,11 & 10) & 130 & 99 & 44 & 29 & 23 & 29 \\
\hline 13,6 & 3 & 16 & 31 & 44 & 14 & 7 & 7 \\
\hline 13,10 & 0 & 0 & 620 & 1,400 & 1,200 & 1,100 & 1,400 \\
\hline 15,4 & 17 & 31 & 35 & 32 & 10 & 1 & 1 \\
\hline 19,5 & 5 & 7 & 18 & 26 & 10 & 0 & 0 \\
\hline 19,9 & 51 & 300 & 240 & 99 & 380 & 410 & 410 \\
\hline 21,9 & 92 & 200 & 250 & 280 & 230 & 100 & 80 \\
\hline 23,10 & 100 & 110 & 39 & 28 & 3 & 1 & 1 \\
\hline 24,6 & 2 & 27 & 27 & 40 & 110 & 25 & 28 \\
\hline 28,10 & 600 & 600 & 740 & 1,300 & 1,000 & 270 & 1,300 \\
\hline 30,9 & 1,200 & 600 & 500 & 520 & 490 & 420 & 560 \\
\hline 32,9 & 0 & 0 & 200 & 390 & 470 & 570 & 540 \\
\hline 35,12 & 1,100 & 550 & 1,200 & 2,000 & 870 & 1,100 & 1,700 \\
\hline Pumpage total & 3,800 & 3,100 & 4,800 & 7,200 & 5,600 & 4,700 & 7,000 \\
\hline \multicolumn{8}{|l|}{ Pumpage-return recharge } \\
\hline 12,9 & $\cdot 0$ & 0 & 140 & 320 & 270 & 250 & 320 \\
\hline 13,9 & 0 & $\mathbf{0}$ & 140 & 320 & 270 & 250 & 320 \\
\hline 14,10 & 0 & 0 & 140 & 320 & 270 & 250 & 320 \\
\hline 19,8 & 16 & 96 & 78 & 32 & 120 & 130 & 130 \\
\hline 20,8 & 30 & 64 & 81 & 92 & 75 & 33 & 26 \\
\hline 20,9 & 16 & 96 & 78 & 32 & 120 & 130 & 130 \\
\hline 22,9 & 30 & 64 & 81 & 92 & 75 & 33 & 26 \\
\hline Pumpage-return recharge total & 92 & 320 & 740 & 1,200 & 1,200 & 1,100 & 1,300 \\
\hline
\end{tabular}


Effluent recharge is ground-water recharge that occurs due to the deep percolation of sewage-effluent water. Significant effluent recharge originated from four sources in the Barstow area: the upper Barstow sewage ponds, the lower Barstow sewage ponds, the USMC sewage ponds, and the USMC golf course (which is watered with treated effluent from the USMC sewage ponds) (fig. 2). The effluent from the Atchison, Topeka and Santa Fe Railway yard at Barstow is included in the data shown for the upper and lower Barstow sewage ponds (table 1 ).

Underflow discharge is subsurface outflow from the model area and occurs along the Mojave River on the north side of the Waterman fault. The large variations in this quantity shown in table 1 are due to correspondingly large variations in the saturated thickness of the aquifer at the lower model boundary.

Model pumpage may represent either the net consumptive use of water extracted from the aquifer, or the total quantity of water extracted from the aquifer. When the pumping well and the area of use are in close proximity, the quantity of extracted water that percolates and returns to the aquifer inay be subtracted from the total extraction from the well to calculate the model. pumpage. However, this can be done only when the degraded chemical quality of the pumpage-return water is not a significant source of ground-water degradation. When the recharge from pumped ground water is significantly different in quality than that initially pumped, the total well extraction is used as the model pumpage and the quantity of pumpage returned to the aquifer is modeled as a separate recharge quantity called pumpage-return recharge. This allows the pumpage-return recharge to be assigned a different chemical quality from that of the ground water and enables the model to consider this recharge as a source of ground-water degradation.

This model has an advantage over other water-quality models that must use a relatively small number of model nodes. When pumpage and pumpage-return recharge are modeled over large areas of an aquifer, the greater number of

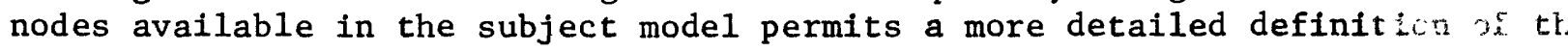
pumpage and recharge effects on the ground-water quality.

Under steady-state conditions the shallow depth to the water table in tivi area of the river largely precluded surface-water recharge. As a result, the only recharge considered in the steady-stats model was underflow recharge from the west of Barstow, 1,600 acre-feet per year, and from the southeas 1 Barstow, 120 acre-feet per year. Underflow discharge was the only signiticant source of discharge under steady-state conditions and totaled about 1,700 acre-feet per year. 
In addition to defining the quantity of water recharging the aquifer, it is also necessary to define the chemical quality of the recharge water. These data are required in both the water-quality model and the steady-state waterquality model. Chemical analyses were used to estimate the quality of the recharge water from the sewage-treatment ponds, as well as that of the underflow recharge from adjacent aquifers. The quality of recharge from irrigation was estimated by calculating the increase in concentration of the applied water due to consumptive use assuming that the plants used no salts. For example, if 1,000 acre-feet per year of applied water is used for irrigation, and consumptive-use requirements are 500 acre-feet per year, it was assumed that the recharge from pumpage return would have twice the concentration of the applied water. The increase in concentration resulting from agricultural fertilizer application was not taken into consideration. Dissolved-solids concentrations were used as the modeled constituent (fig. 3 ).

\section{Historic Data on Head and Water Quality}

To provide a basis for verification, data on historic head and water quality must be available over a period of years to be simulated in the water-quality model. The comparison of model-generated heads and water quality with historic heads and quality may be made on the basis of contour maps, change maps, or hydrographs. Six water-level hydrographs of wells were used in the verification of the hydraulic phase of the Barstow water-quality model (fig. 6). The chemical-quality phase of the model was verified by comparing model-generated water-quality information with the water-quality hydrographs of 11 wells, six of which are shown in figure 7 . A steady-state head contour map and water-quality contour map were generated by the steadystate model and were verified by comparison with field data representative of the near-pristine conditions prior to 1946 (figs. 8 and 9).

The steady-state water-quality contour map was modified in the vicinity of the upper Barstow sewage ponds to represent the non-pristine water-quality conditions that prevailed in 1945 due to the prior operation of the upper Barstow sewage ponds (fig. 9). Available data were not adequate to document the effect of dispersion in steady-state conditions, and the steady-state model (appendix), without the effects of dispersion, was used to calculate steady-state water-quality conditions. The modified steady-state waterquality map and the steady-state head map were used to define the initial water-quality and head conditions at the start of the model period for the Barstow water-quality model. 

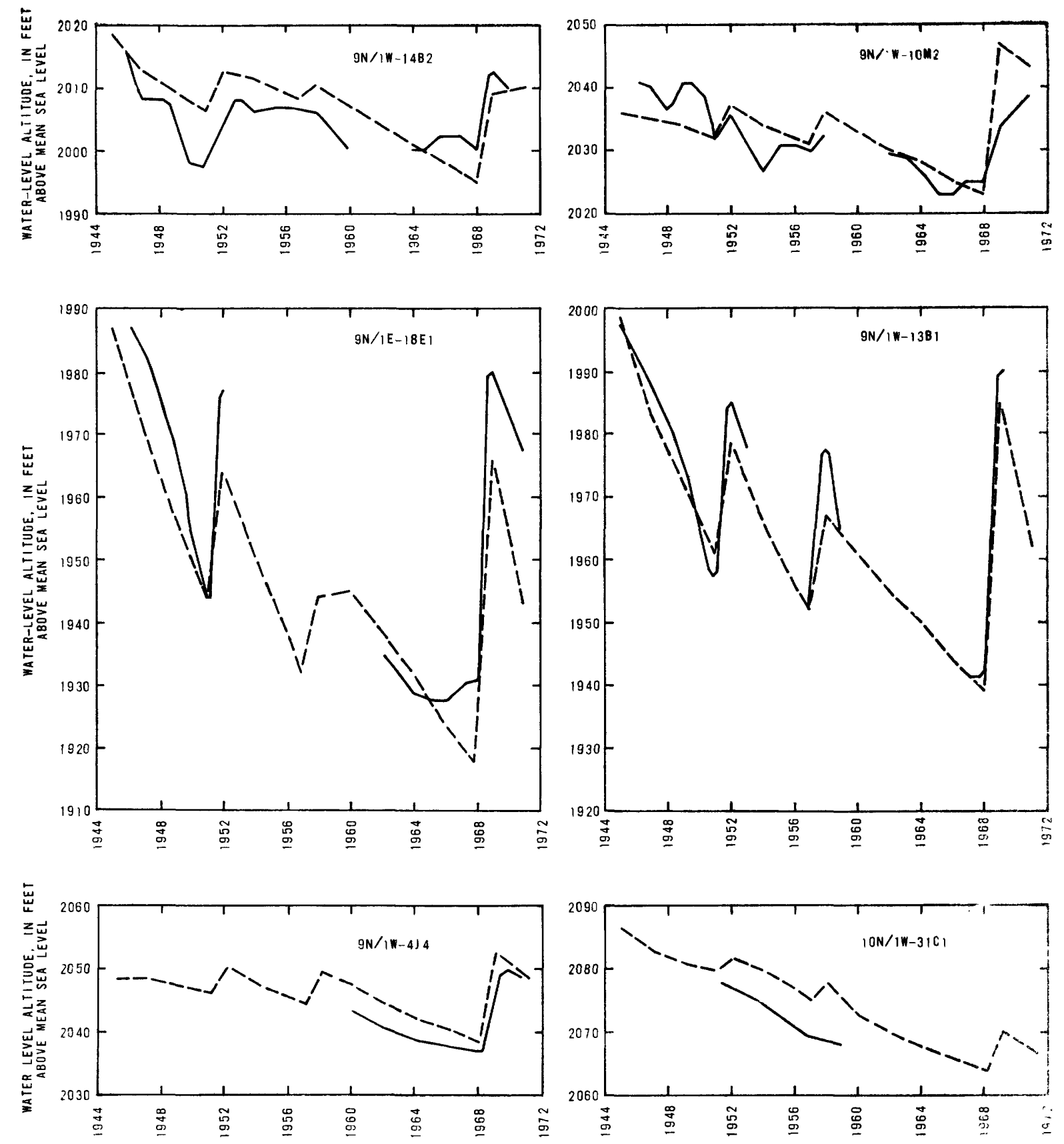

EXPLANATION

Historic water-level hydrogıaph
Model-generated water-level hydrograph

FIGURE 6.--Comparison of historic water-level hydrographs and model-generated water-level hydrographs. 

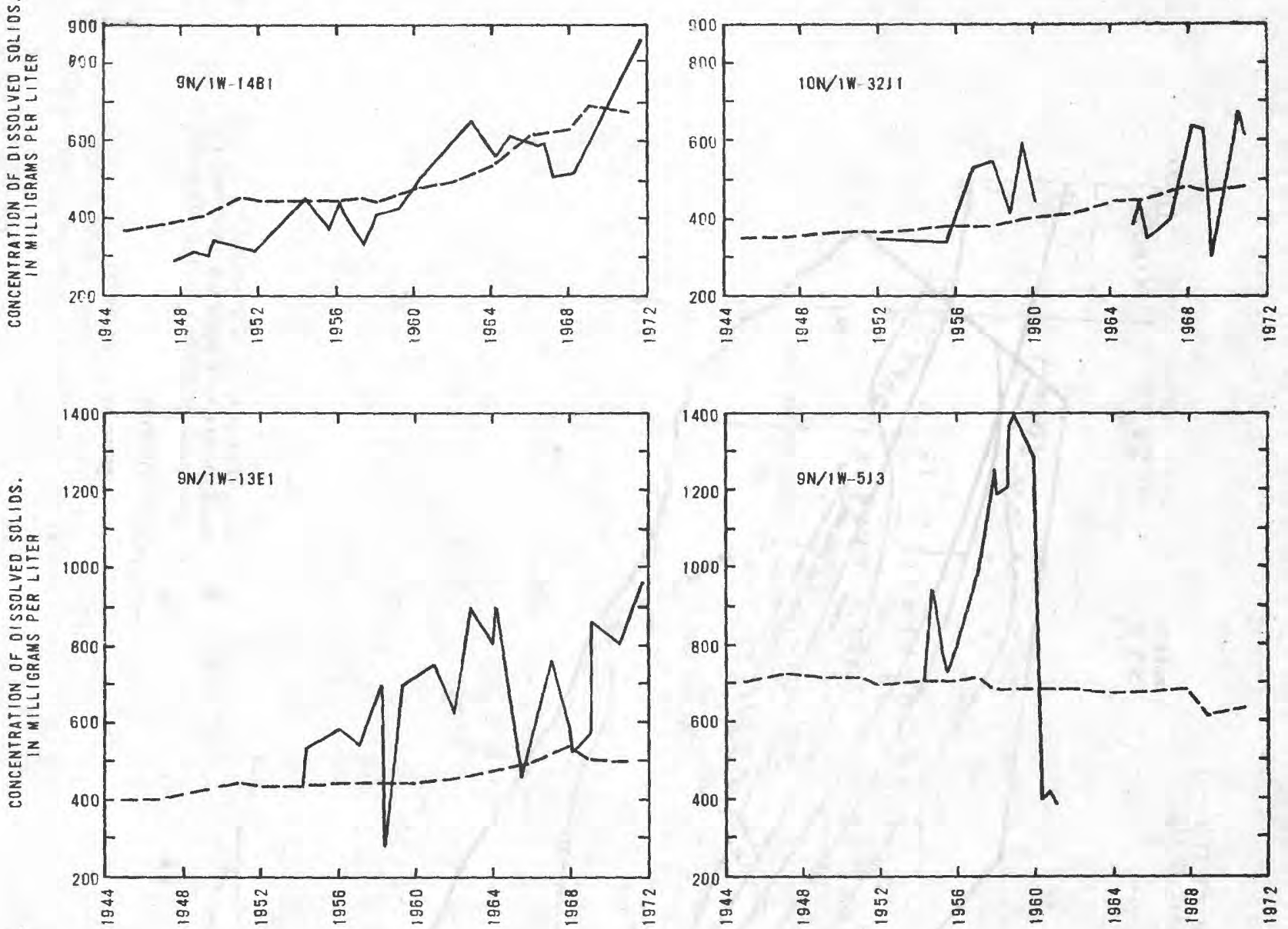

号
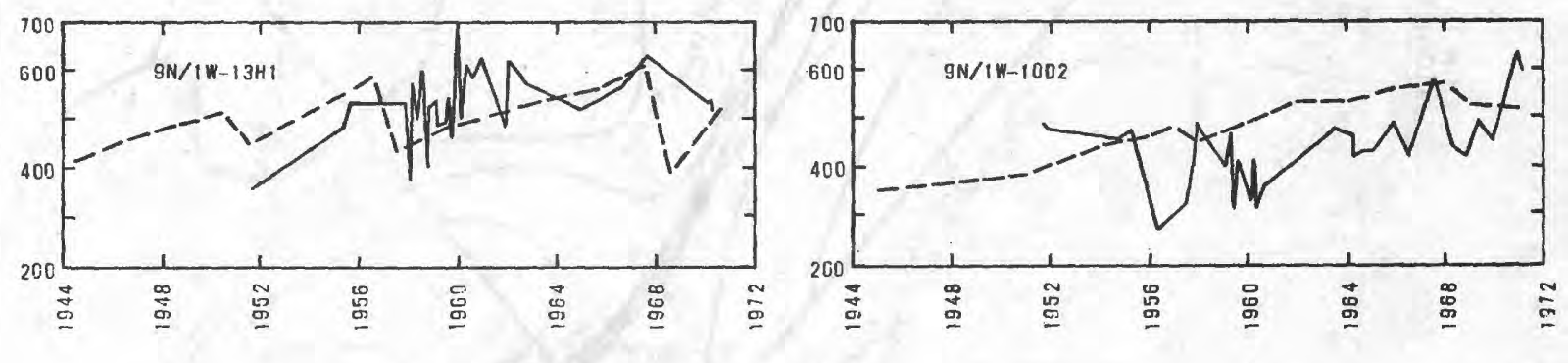

\section{EXPLANATION}

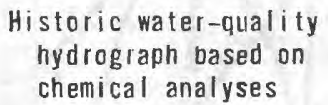

Model-generated water-

chemical analyses

FIGURE 7.--Comparison of historic water-quality hydrographs and model-generated water-quality hydrographs. 

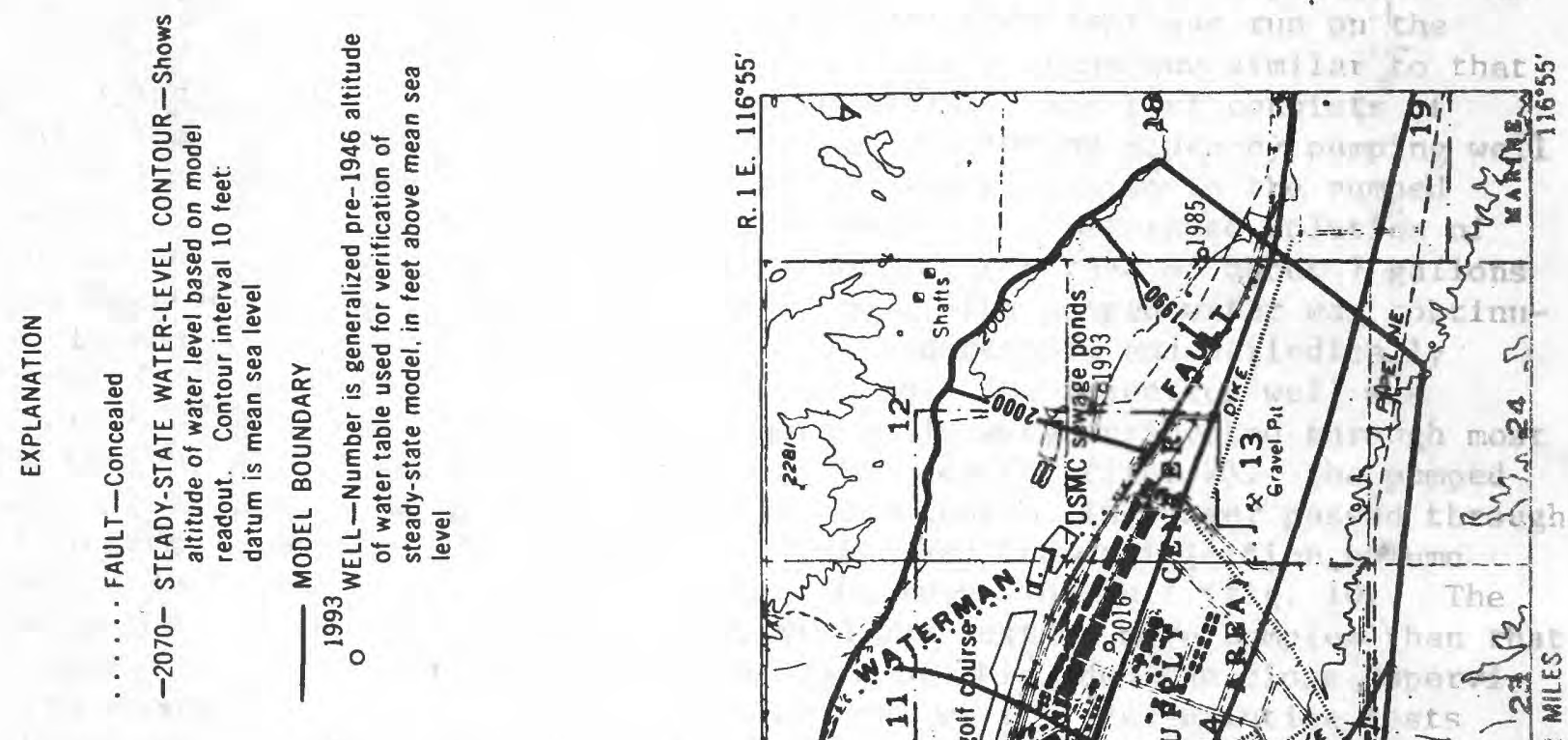

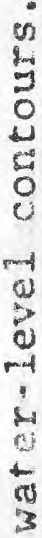

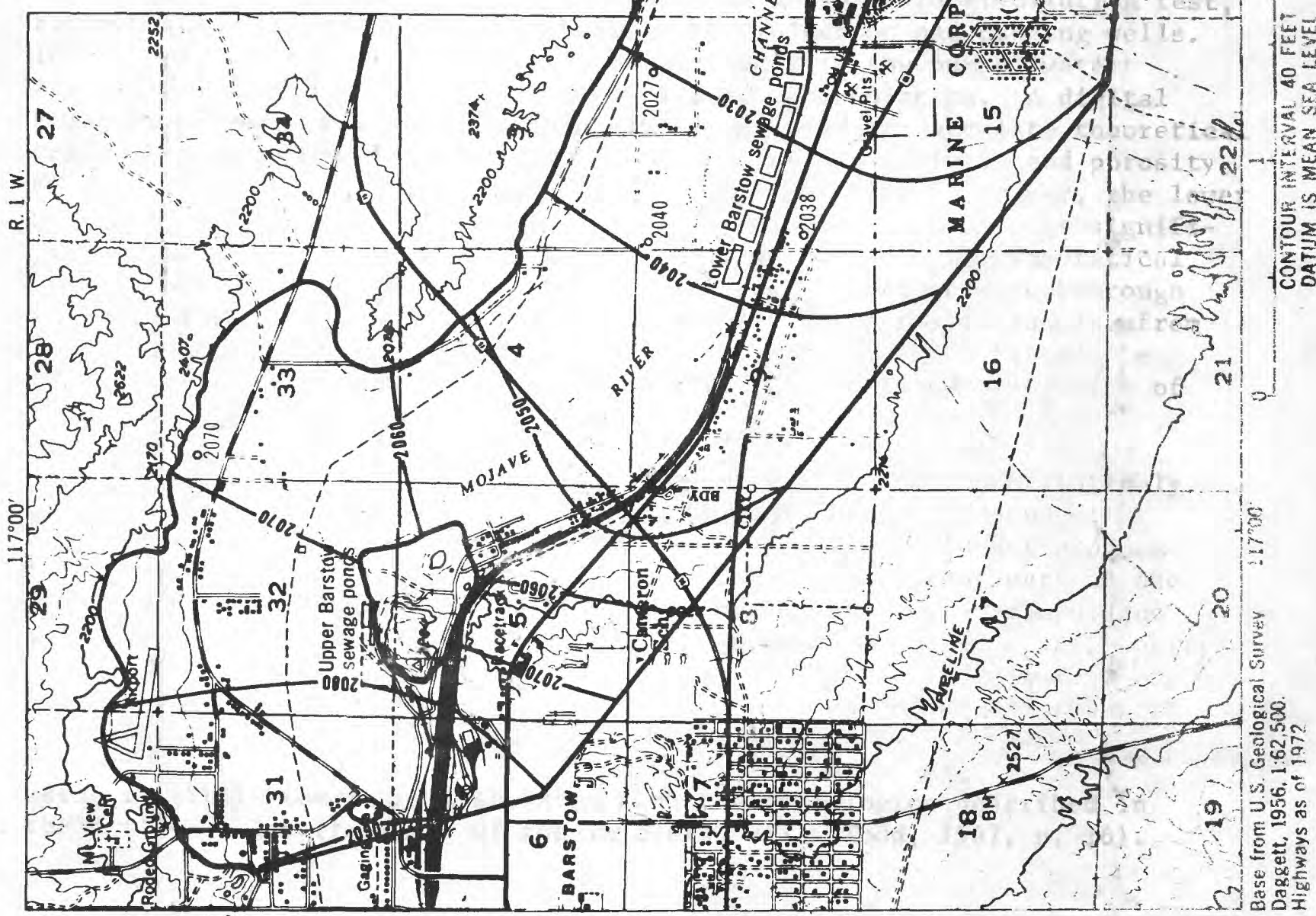



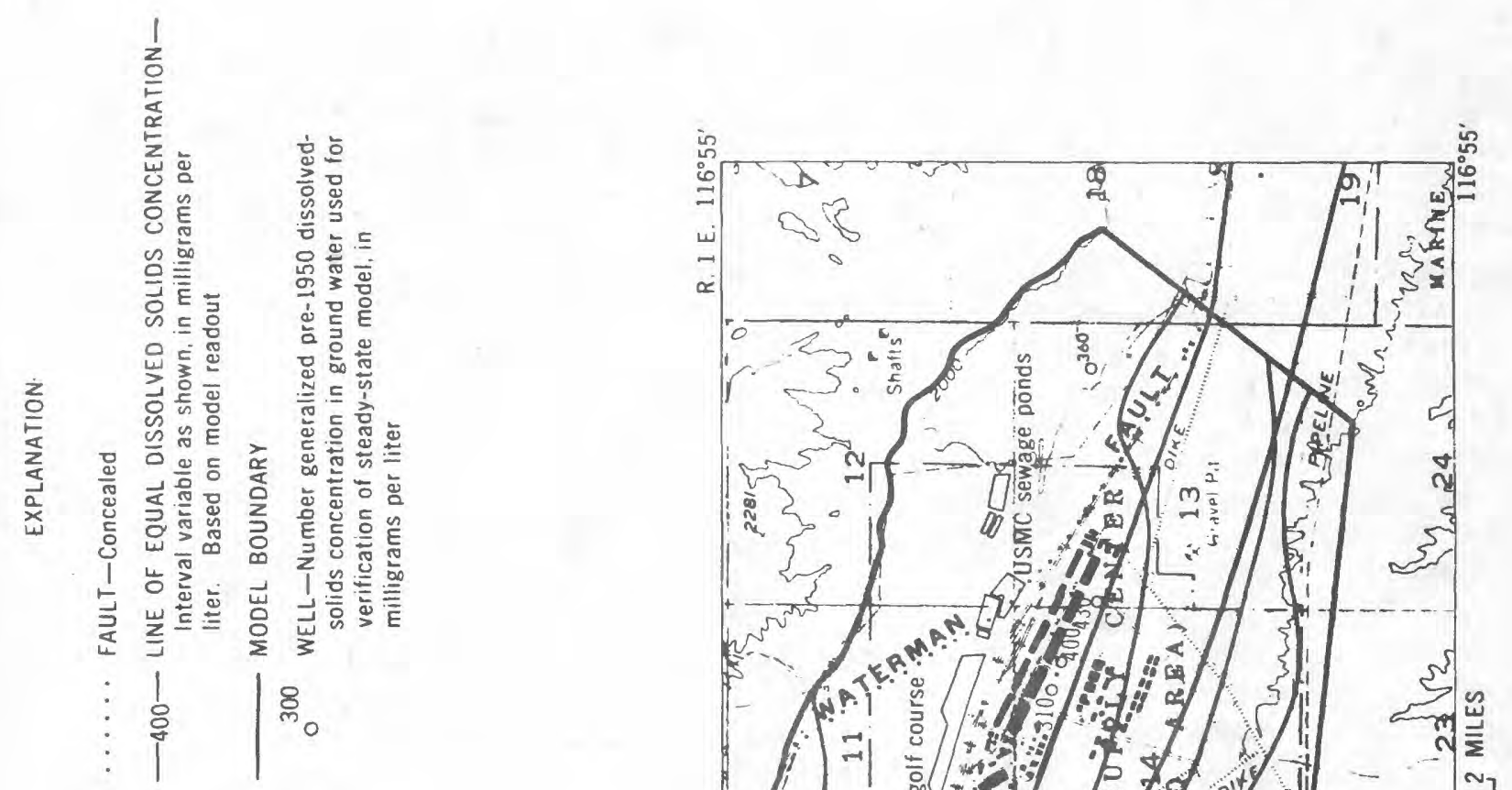


\section{Dispersivity}

In order to make a field determination of the dispersivity required in the water-quality model, a two-well tracer-dilution test was run on the younger alluvial aquifer north of Barstow using a technique similar to that described by Webster, Proctor, and Marine (1970). The test consists of injecting à chemical tracer into a well and monitoring a nearby pumping well to determine the rate of increase in tracer concentration in the pumped water. In this test the tracer was introduced as a saturated solution of sodium chloride that was continuously injected at a rate of about 7 gallons per hour during the 84-hour span of the test. The pumped water was continuously monitored for changes in electrical conductivity and periodically sampled for changes in chloride concentration. The injection well was 21 feet west of the pumped we11, and both wells were perforated through most of the 90 feet of saturated thickness of the aquifer (fig. 2). The pumped well discharged at a rate of 55 gallons per minute. The water passed through a flowmeter, conductivity-monitoring column, and tracer-injection column before returning to the aquifer through the injection well (fig. 10). The apparatus used in the two-well tracer-dilution test is more complex than that required for a standard pump test. Because of this, and the close supervision required to assure proper operation, two-well tracer-dilution tests should not be undertaken without thorough consideration.

Because of the particular technique used in this tracer-dilution test, recirculation of tracer occurred between the injection and pumping wells. The increase in relative concentration of tracer in the pumped water (fig. 11) included the effects of this tracer recirculation. A digital computer program presented by Grove (1971) was used to calculate theoretical tracer-breakthrough curves for various values of dispersivity and porosity. Because the program can consider only one recirculation of tracer, the lower parts of the curves (where the effects of recirculation are least significant) were mainly used to determine the best fit between the theoretical breakthrough curves and the field data. A series of tracer-breakthrough curves was calculated for value of dispersivity and porosity ranging from 30 feet to 400 feet and 26 percent to 40 percent. The best fit of the field data was obtained with a dispersivity of 50 feet and a porosity of 40 percent.

Grove (1971, p. 22) stated that, "Although it is not quantitatively proven, the porosity and the dispersion constant seemed independent of each other to the extent that combinations of the two would not produce identical curves. Variations in porosity affect a different part of the curve than variations in dispersion constant. A decrease in dispersion constant displaced the curve to the right, whereas an increase in porosity flattened the curve in this same direction." Similar effects were found in this work, although the shape of the breakthrough curves was found to be much more sensitive to porosity than to dispersivity. Although the porosity of the alluvium was not determined by other means, the above value is within the range associated with the lithologies described in the driller's log (table 2) of the injection well (Todd, 1967, p. 16). 


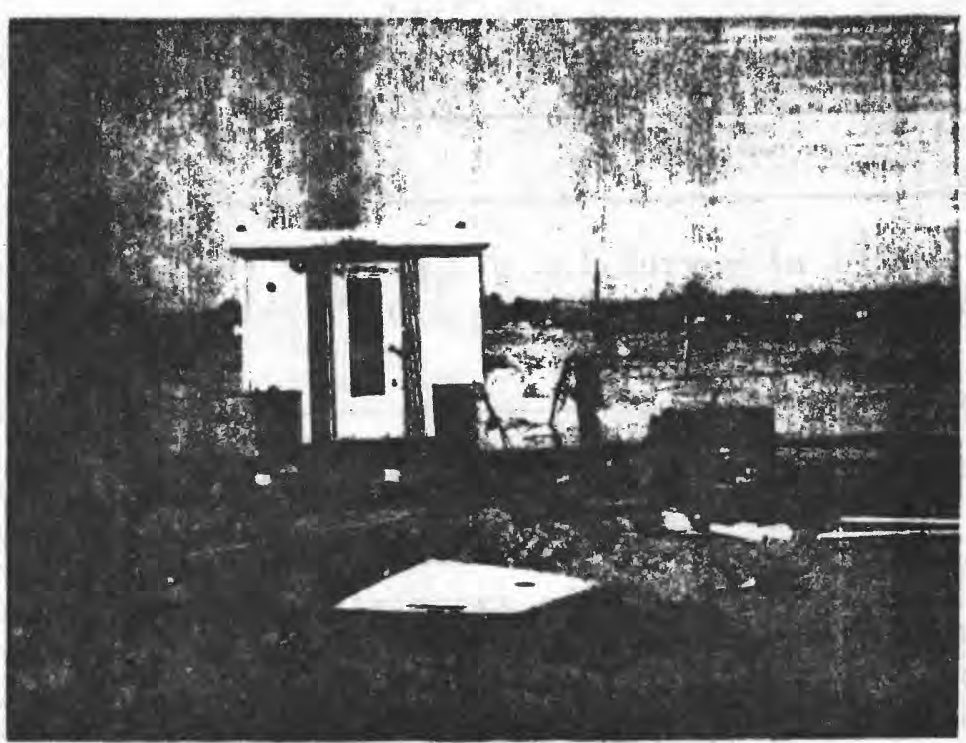

23

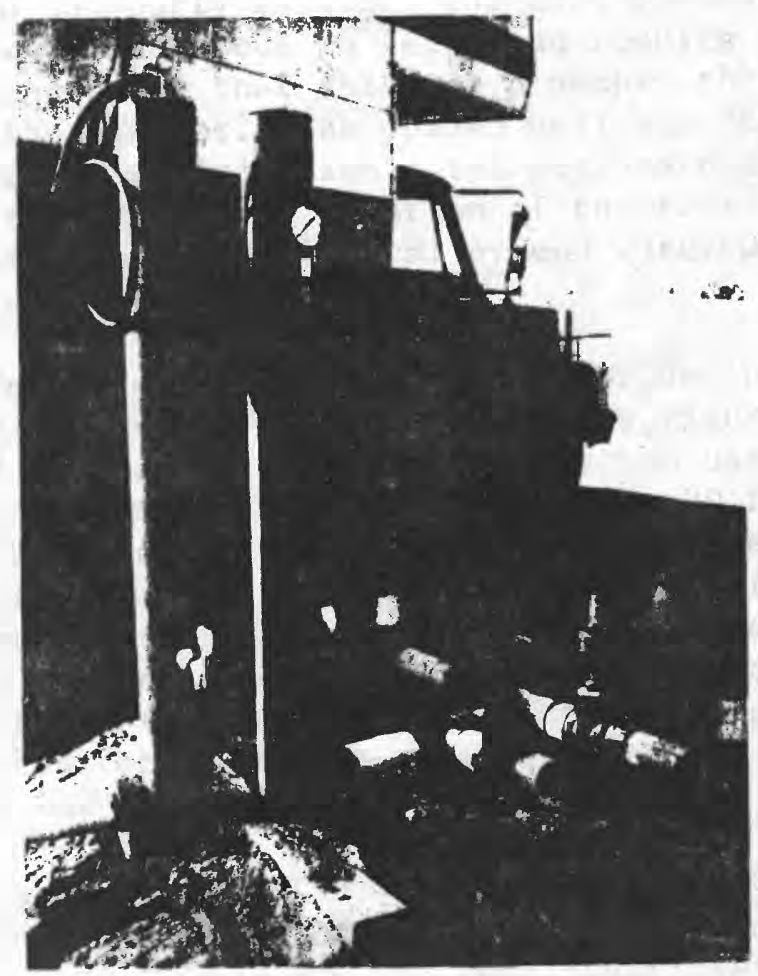

$37 a(38$ fola $)$ 


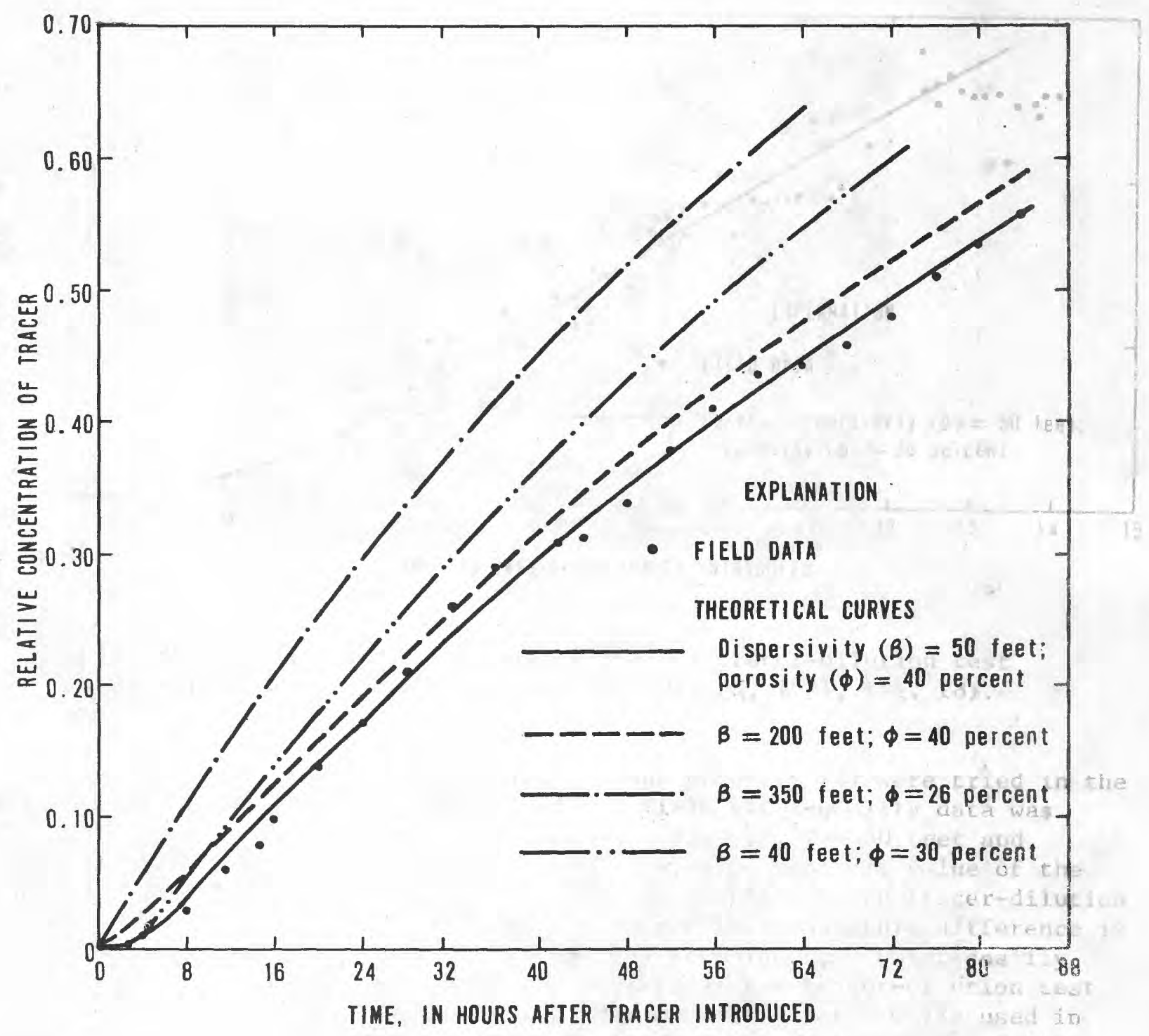

FIGURE 11.--Tracer-breakthrough curves for tracer-dilution test.

Wilson (1971) presented data from a more extensive two-well tracer. dilution test with a greater distance between pumping and injection we11s than in the test near Barstow. This test measured conditions over a larger area of aquifer than did the test near Barstow and did not involve tracer recirculation. Analysis of data from this test could indicate whether or not comparable results were obtained from the less extensive dispersion tests at Barstow. 
TABLE 2.--Driller's log of injection well at two-well tracerdilution test site

10N/1W-32G3. Drilled by U.S. Geological Survey in 1971. 2-inch polyvinylchloride casing to 108 feet, perforated from 23 to 108 feet. Altitude about 2,085 feet.

Sand, medium to very fine, with silt

Gravel, fine to medium, with thin stringers of silt and clay-_-

Sand, very coarse to fine, with stringers of medium

grave1-

Sand, coarse to fine-

Sand, coarse to fine, very clean-_

Sand, coarse to fine, with a few thin stringers of silt

and clay-

$\begin{array}{ll}10 & 10 \\ 7 & 17 \\ 18 & 35 \\ 10 & 45 \\ 10 & 55 \\ 65 & 120\end{array}$

The test was run on an older alluvial aquifer near Tucson, Ariz. The aquifer consisted of unconsolidated mixtures of gravel, sand, silt, and clay ranging from well sorted to poorly sorted. The most permeable zones had a combined saturated thickness of about 14 feet, and results (Wilson, 1971, p. $30,35,63,77,78$ ) indicated that this was probably the effective saturated thickness of the aquifer. The pumped well was 260 feet from the injection we11, and pumping and injection rates were maintained at about 200 gallons per minute for the 14-day duration of the test. Water with a higher chloride concentration than the local ground water was continuously injected, and chloride was used as the tracer.

The time-variant relative concentration of chloride in the pumped water was shown by Wilson (1971) and is replotted herein as figure 12. The same curve-fitting procedure was used with these data as was used with those from the test near Barstow. Values of dispersivity between 20 feet and 200 feet and values of porosity between 10 percent and 40 percent were considered. The best fit of the field data was obtained with a dispersivity of 50 feet and a porosity of 38 percent, results that are in close agreement with those from the test near Barstow. In view of the basic similarities of the effective saturated intervals in these two tests, it seems that the shorter dispersion test near Barstow produced consistent results and that the error introduced by tracer recirculation may have been minor.

A series of model runs was made to determine what values of dispersivity and porosity would give the best verification of the water-quality model. This provided an opportunity to compare the model-determined dispersivity with that based on the two-well tracer-dilution tests and to examine how the model responded to variations in these parameters. 


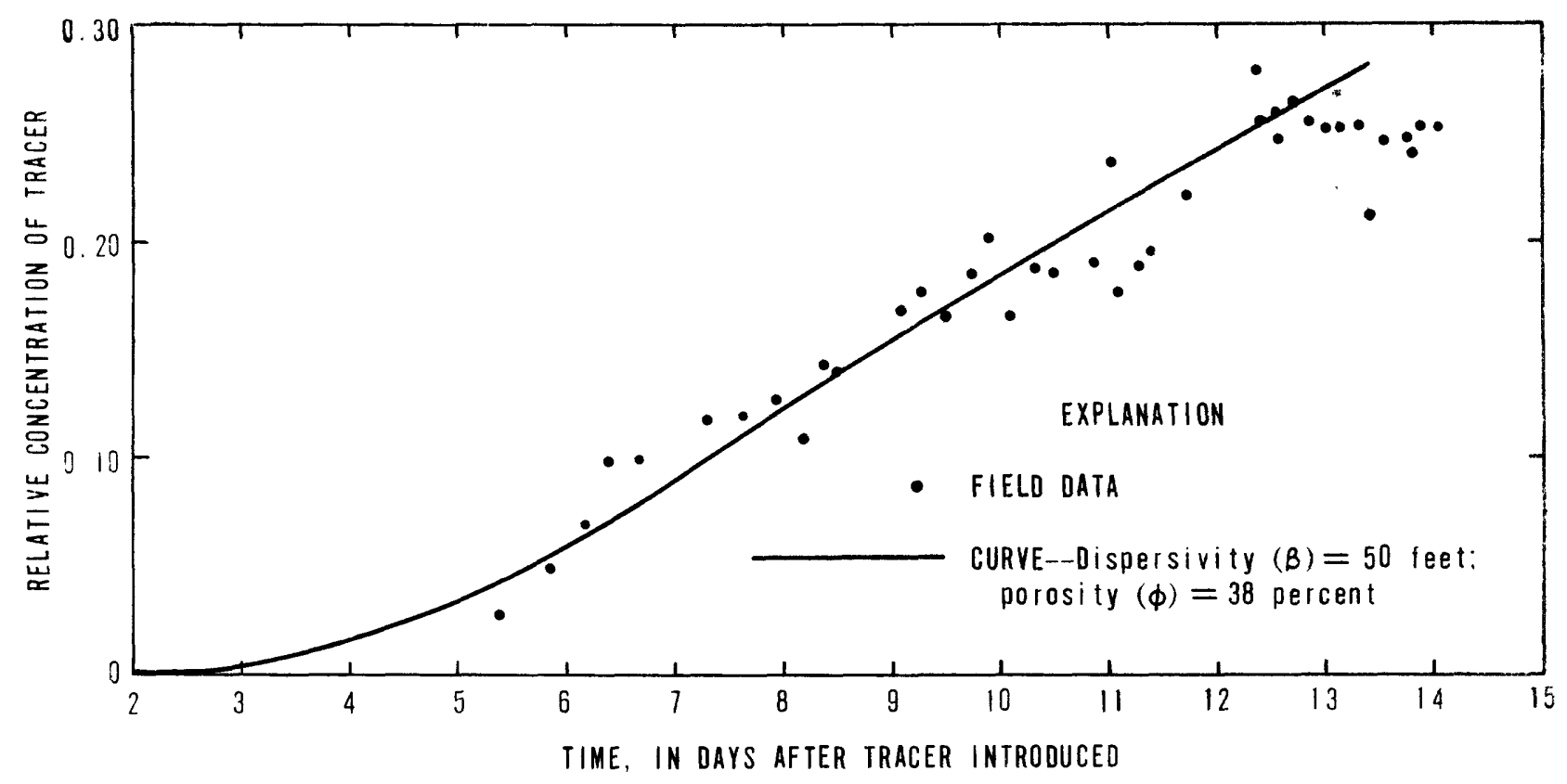

FIGURE 12.--Tracer-breakthrough curve for tracer-dilution test near Tucson, Arizona (replotted from Wilson, 1971, fig. 18).

Several values of the dispersivity $(\beta)$ and porosity $(\phi)$ were tried in the water-quality model, and the best fit of the field water-quality data was achieved with $\beta=200$ feet and $\phi=40$ percent; however, $\beta=50$ feet and $\phi=30$ percent also produced reasonable results. The best fit value of the dispersivity is not in close agreement with the results of the tracer-dilution tests run near Barstow and Tucson. In order to assure that this difference is not due to incompatability of the mathematical techniques, a water-qualiiy model with a 5-foot grid interval of the aquifer at the tracer-diiution test site was built. The model simulated the pumping and recharge wells used in the tracer-dilution tests and calculated the relative concentration of the injected tracer in the pumped well at 24-hour intervals with recirculation of tracer at 8-hour intervals.

The tracer-breakthrough curve shown in figure 13 was calculated by the sma11-scale model of the tracer-dilution test site. Values of $\beta$ and $\phi$ between 10 feet and 300 feet and 25 prccent and 40 percent were tried, with the best fit of the field data occurring at $\beta=50$ feet and $\phi=35$ percent. These values are in close agreement with those indicated by the analysis of the tracer-dilution test using the technique presented by Grove (1971). These results seem to indicate either that the small-scale tracer-dilution test did 
not give a valid indication of the dispersivity of the aquifer on the large scale used in the water-quality model or that the best model verification should have occurred with dispersivities nearer 50 feet. Because of the relative Insensitivity of the model to dispersivity, the latter possibility cannot be entirely ruled out; however, J. D. Bredehoeft (written commun., 1973) suggests that the former situation is a likely source of the problem.

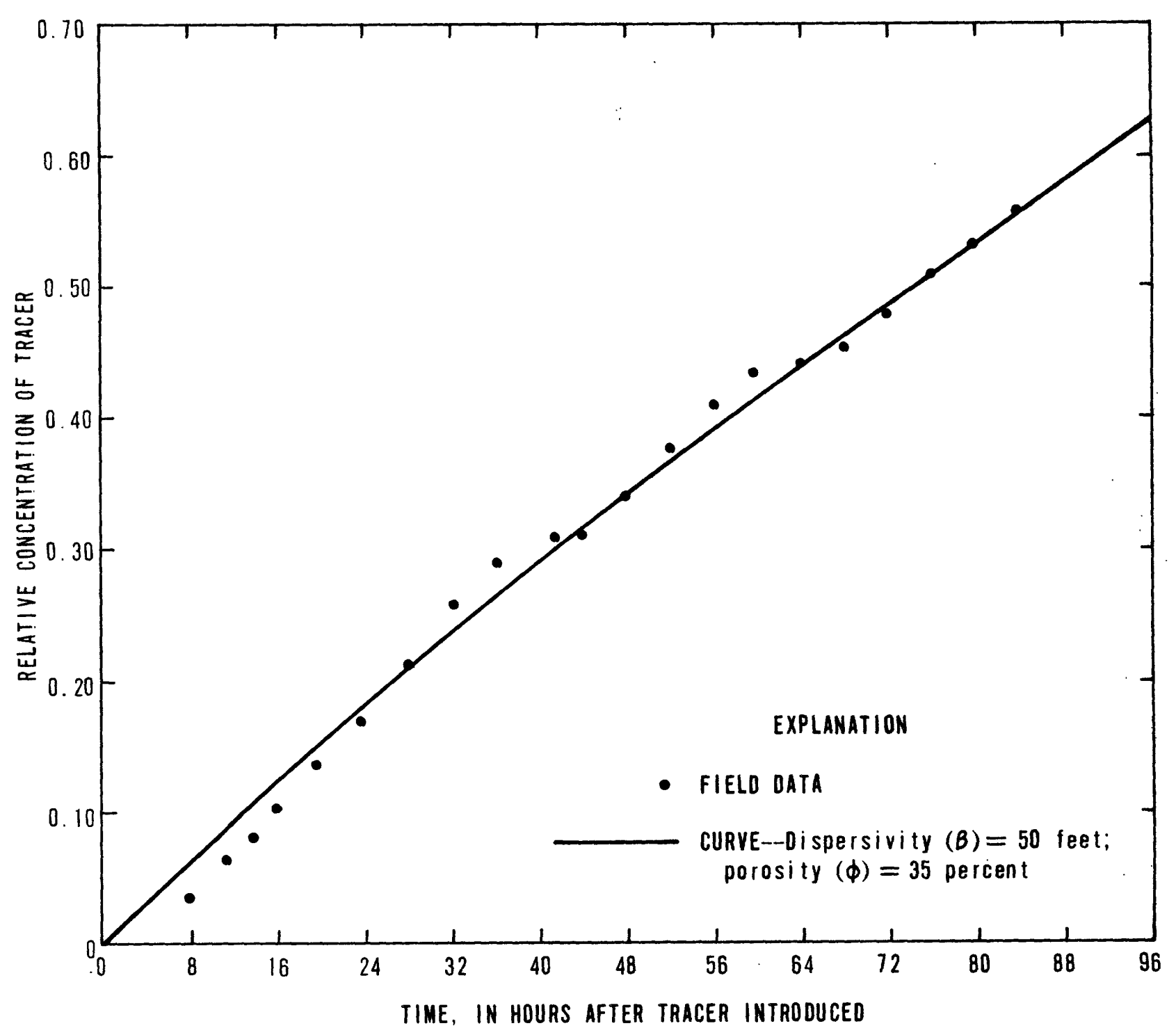

FIGURE 13.--Mode1-generated tracer-breakthrough curve. 
In order to determine how the model responded to variations in dispersivity and porosity, three otherwise identical model runs were made with the following values: $\beta=50$ feet, $\phi=40$ percent; $\beta=50$ feet, $\phi=30$ percent; and $\beta=200$ feet, $\phi=40$ percent. A profile of the modelgenerated relative dissolved-solids concentration along column 9 is plotted in figure 14 to show the effects of the variations in porosity and dispersivity on the concentration. As shown in figure 14, decreasing the porosity from 40 percent to 30 percent produced an increase in concentration at nodes on the downgradient edge of the degraded plume but did not significantly affect the concentration at any other nodes on the profile. A much more widespread increase in concentration was produced on the downgradient edge of the plume by increasing the dispersivity. An increase in dispersivity also produced a decrease in concentration of the plume near the source of the degraded water. Thus, increasing the model dispersivity tended to flatten and broaden the plume of degraded water.

In order to evaluate the feasibility of running tracer-dilution tests prior to constructing a water-quality model, it is important to know the sensitivity of the model to dispersivity. The degree of sensitivity can be illustrated by comparing model runs from the Barstow water-quality model with model runs from a water-quality model for part of the Coachella Valley, Calif., and a small-scale water-quality model of an area near Barstow. Concentration profiles similar to those in figure 14 are shown in figures 15 and 16 for each of the other two models. The grid intervals used in the three models varied from 5 feet in the small-scale model (fig. 16), 1,000 feet in the Barstow water-quality model (fig. 14), to 5,280 feet in the Coachella Valley model (fig. 15). It can be seen by a comparison of the figures that for a given simulation period the larger the grid interval, the less sensitive the model is to changes in dispersivity. For example, at a grid interval of 5 feet (fig. 16), an increase in $\beta$ from 0 to 200 feet caused a 5-percent reduction in the concentration near the source of the degraded plume in a time span of 24 hours. At a grid interval of 1,000 feet (fig. 14), an increase in B from 50 feet to 200 feet (analogous to an increase in $\beta$ from 0 to 200 feet) caused a 10-percent reduction in the concentration near the source of the plume in a 6-year time span; and at a grid interval of 5,280 feet (fig. 15), an increase in $\beta$ from 0 to 100 feet caused no change after a 2-year time span and caused only a 5-percent reduction in the concentration after a 50-year time span. Although a $\beta=0$ condition is not shown in figure 14, the change in concentration at the peak of the plume would be identical to that for $\beta=50$ feet, because the relative concentration can never exceed 1.0 for any value of $\beta$. 


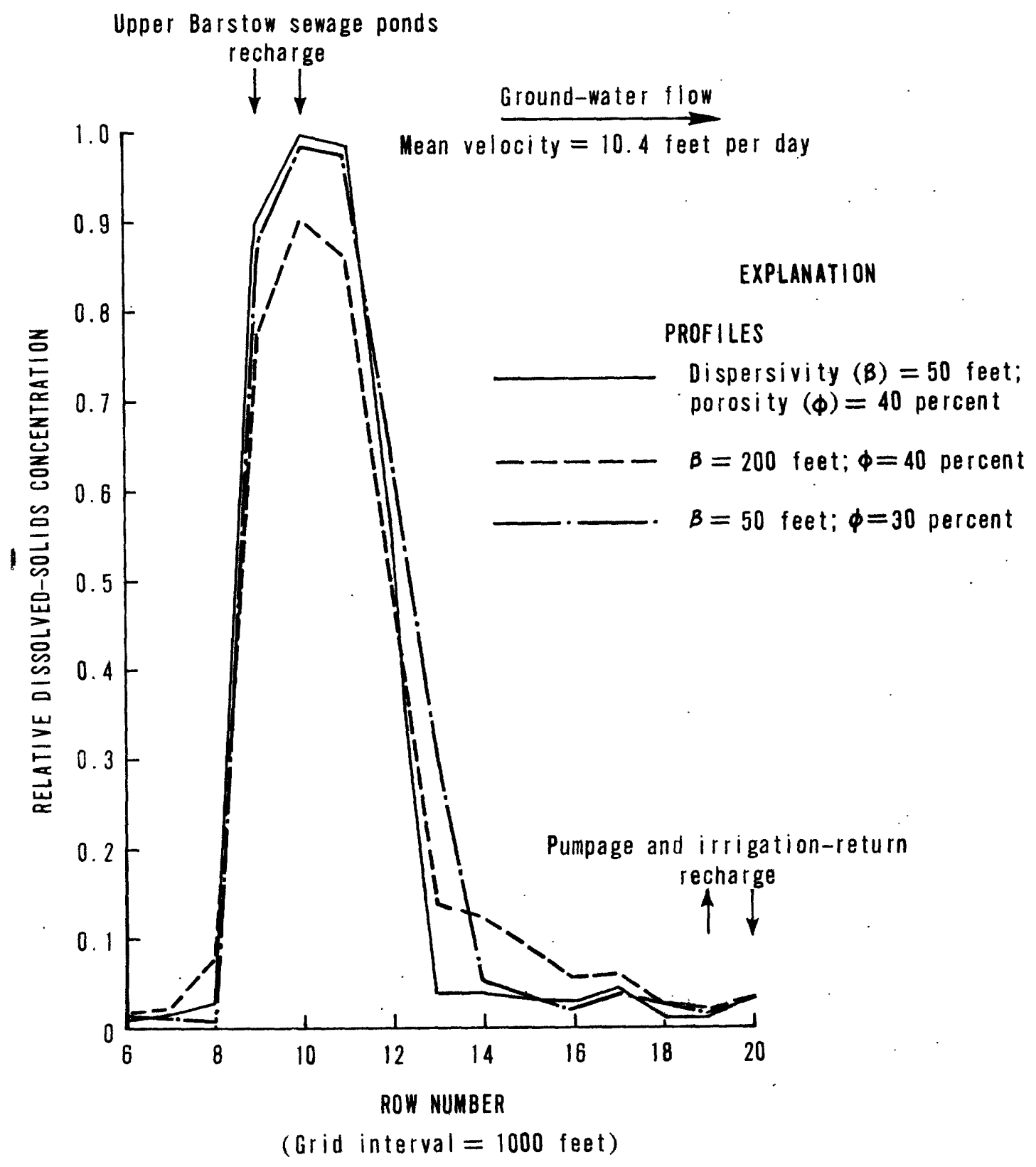

FIGURE 14.--Mode1-generated concentration profiles along column 9 of water-quality model after 6 years of recharge from upper Barstow sewage ponds. 


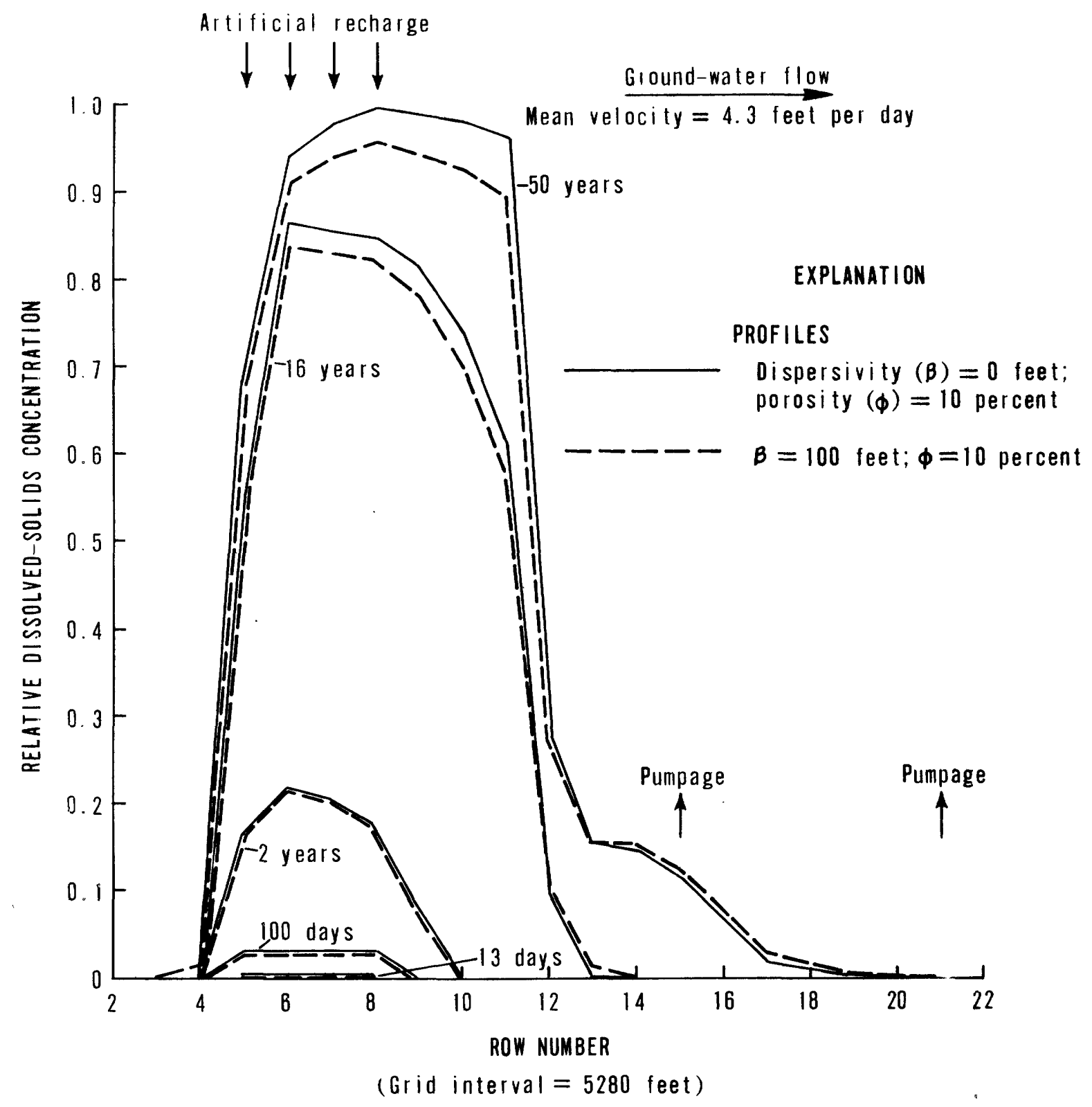

FIGURE 15.--Variation in model-generated concentration profiles with time along column 11 in a water-quality model of part of Coachella Valley, California. 


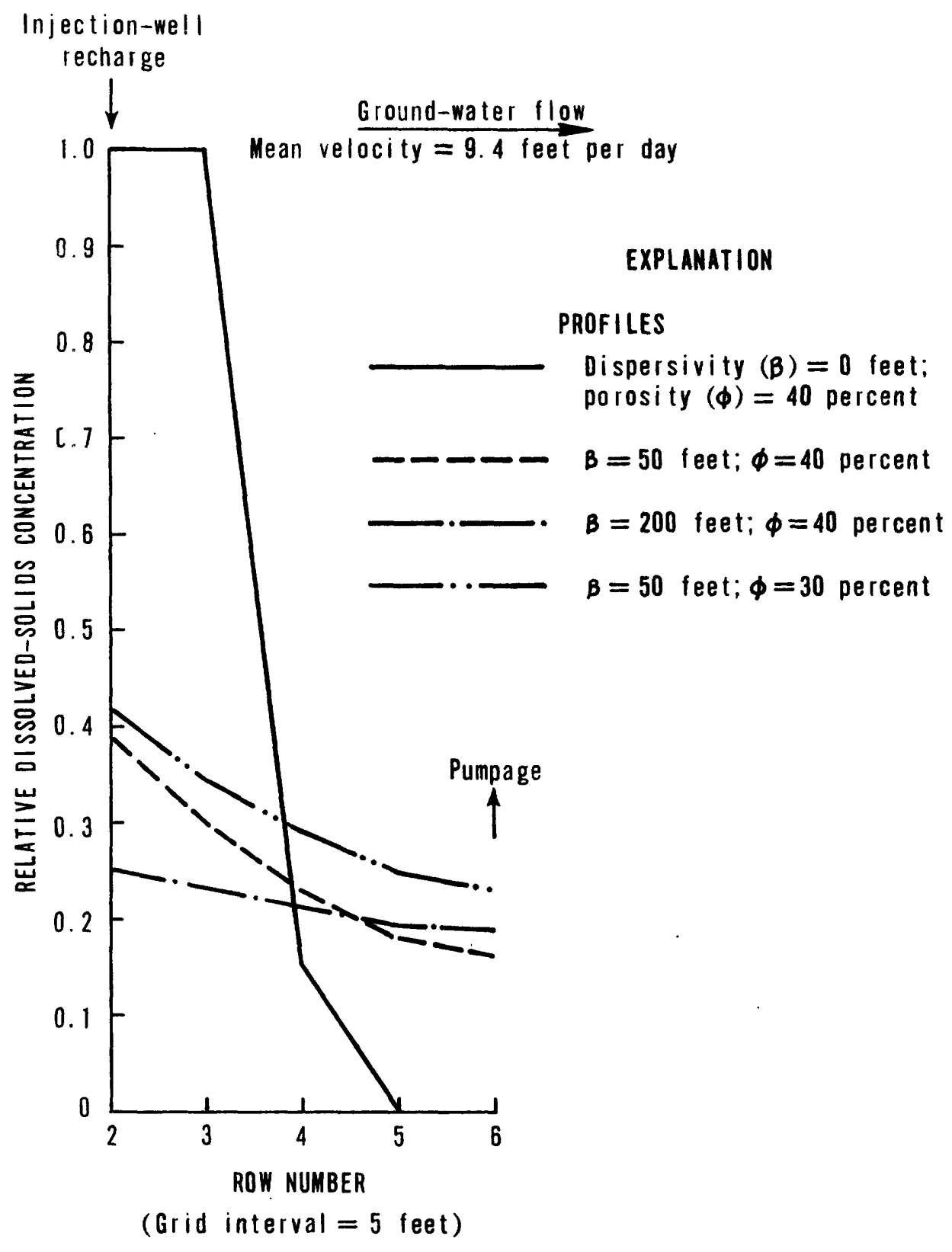

FIGURE 16.--Model-generated concentration profile along column 4 in a small-scale model after 24 hours of injection-well recharge. 
The feasibility of running two-well tracer-dilution tests must be judged on the basis of each proposed model. If a basin-wide model with a large grid interval is under consideration, tracer-dilution tests are probably not necessary (1) because of the relative insensitivity of the model to dispersivity during even long simulation periods, and (2) because the dispersivity measured in a small-scale tracer-dilution test probably is not indicative of the large-scale dispersivity required by the water-quality model. However, if a model with a small grid interval is under consideration, the model should be sensttive to variations in dispersivity during even short simulation periods. In this situation the time and the expense involved in a two-well tracer-dilution test might be justified if the aquifer is very uniform so the results of the tracer-dilution test can be applied to the entire model area.

Like hydraulic modeling, water-quality modeling is feasible only when adequate data are available to define the model parameters. Historic data describing the head and water quality in the aquifer, pumpage, and quality of the ground-water recharge are of prime importance. Without these data the model cannot be properly verified. Most of the hydrologic data required for the water-quality model are more readily determined than dispersivity and may be partially or wholly available in areas with prior hydrologic investigations. In general, the data requirements for the model are not so excessive as to markedly affect the applicability of the water-quality model.

\section{WATER-QUALITY MODELING--DIFFICULTIES AND LIMITATIONS}

In the course of this study several problems occurred that were inherent to the characteristics of the water-quality model computer program. Because the computer program is undergoing constant change and revision, some of the difficulties discussed here will have been corrected or improved upon by the. time this report is published. In this study three problems affected the concentration calculations in the model.

The first and most significant problem was the result of head declines that were large in relation to the saturated thickness of the aquifer. This caused some nodes to become void of the mathematical particles used in calculating the concentration. When this occurred, the resulting concentrations were often as much as two orders of magnitude greater than the correct valiu. This usually rendered the water-quality part of the model run useless. No attempt was made to correct this problem. As a result the model was unable to calculate the water-quality configurations resulting from several of the proposed ground-water management practices to be evaluated. One possibje solution to the problem (oral commun., J. D. Bredehoeft, 1972) might be to periodically redistribute the particles to the nodes. This presents a dual problem of preserving the effects of the existing particle distribution and 
determining the proper location within the node to insert new particles. The problem of nodes vacant of particles is of prime importance, and an intensive effort should be made to remedy this problem.

The second problem affecting the concentration calculations seemed to be the result of instability in the explicit procedure used in calculating the change in concentration due to dispersion (written commun., J. D. Bredehoeft, 1972). This problem produced highly localized errors in which the calculated concentration at adjacent nodes varied widely (for example, $-2,000 \mathrm{mg} / 1$ to $4,000 \mathrm{mg} / 1$ ). Model runs in which this problem occurred were sometimes usable because of the limited area affected by the error. After completion of the work on this project the computer program was modified (written commun., J. D. Bredehoeft, 1972) to correct this problem. The modified program occasionally produced irregularities in the concentration configuration, though of a much smaller magnitude than previously. Additional information on the source and effects of these model-generated fluctuations would be of value; however, sufficient time was not available to thoroughly evaluate the effects of this program modification.

The third problem affecting the concentration calculations concerned variations in the background concentration and was not serious. Ideally, the background concentration in the model should remain constant in time unless it is affected by inflow of water of a different concentration. In practice, the background concentration in areas not influenced by water of different quality was found to vary by as much as \pm 10 percent. Thus, gradual increases or decreases in the model-generated concentration with time could be due to the dispersion calculations in the model program rather than to true changes in water quality.

Two other difficulties in the water-quality model occurred as a result of the model program decreasing the transmissivity $(t)$ of the shallow alluvial aquifer as the saturated thickness of the aquifer declined. If the saturated thickness decreases to less than 10 percent of its starting thickness, the model program sets the $T$ at the nodes involved to zero and all other parameters associated with those nodes are also set to zero and are no longer available within the program. This does not cause problems as long as no water-level recovery occurs during the remainder of the simulation period. If subsequent recovery occurs, two options are readily available: (1) Allow the zero $T$ nodes to remain in the model for the remainder of the simulation period and assume that the error introduced by the altered configuration of the aquifer is minor, or (2) modify the program so $T$ is not set to zero when the saturated thickness decreases beyond 90 percent, on the assumption that the error introduced by not dewatering this part of the aquifer is minor. In the Barstow model the second alternative was chosen. The ideal solution would be to modify the program to better handle this situation; however, a technique that would readily do this is not apparent, and the time required to achieve a partial solution may not be warranted. 
The barrier effect of the Waterman fault may begin at about 15 feet below land surface in the riverbed and become increasingly effective with greater depth. The fault was initially assumed to become nearly impermeable, at depths much shallower than the base of the alluvial aquifer. This caused difficulties when attempts were made to model the fault with a smaller, saturated thickness than that of the surrounding aquifer. When the model program reduces the $\mathrm{T}$ of the aquifer in response to a decline in saturated thickness, the $T$ of the fault decreases more rapidly than that of the surrounding aquifer (fig. 17). This greatly increases the number of iterations required in the model calculations and makes the computer cost for the model run prohibitively high. With a fixed-interval grid, any large change in $T$ (in excess af two or three orders of magnitude, for example) between adjacent model nodes has this effect. Thus, aquifers that contain abrupt changes in $T$ or saturated thickness are not easily simulated with the water-quality model program. In the Barstow water-quality model the saturated thickness of the fault was ultimately assumed equal to that of the surrounding aquifer to avold this problem.

The situation could be avoided if the model program were modified to allow use of variable grid intervals. With this modification additional nodes could be located between nodes of markedly different $T$ or saturated thickness to prevent excessive change in $\mathrm{T}$ between adjacent nodes.

In addition to being cognizant of the characteristics of the model program, it is necessary to be aware of the limftations imposed by some of the assumptions made in water-quality modeling. For example, in the water-quality model it is assumed that the aquifer in each node area is homogeneous and isotropic and that head and water-quality changes occur uniformly throughout the saturated thickness. The alluvial aquifer near Barstow is very uniform and largely devoid of confining layers (table 2). However, even in this uniform material, head and water-quality changes occur vertically within the aquifer (fig. 18). The water-quality stratifications are not only due to heterogeneities in the aquifer but may also be due to temperature or density. differences between waters of dissimilar quality, or mechanical stratification as occurs in the Mojave River when good-quality surface water percoletes and forms a layer over the poorer quality ground water. As a result, the generalized water-quality configuration produced by the model is sometimes difficult to correlate with the quality of water pumped from wells that may derive water from particular zones. A similar problem exists when comparing the model-generated head data with water-level measurements. However, this problem is less significant at Barstow because the variation in head with depth is small in comparison to the variation in water quality with depth. Thus, it can be more important to have detailed definition of water-quality changes in depth, area, and tine than to have detailed definition of head changes in these dimensions. The additional quality data would allow a more accurate estimate of the average water quality throughout the saturated interval. 


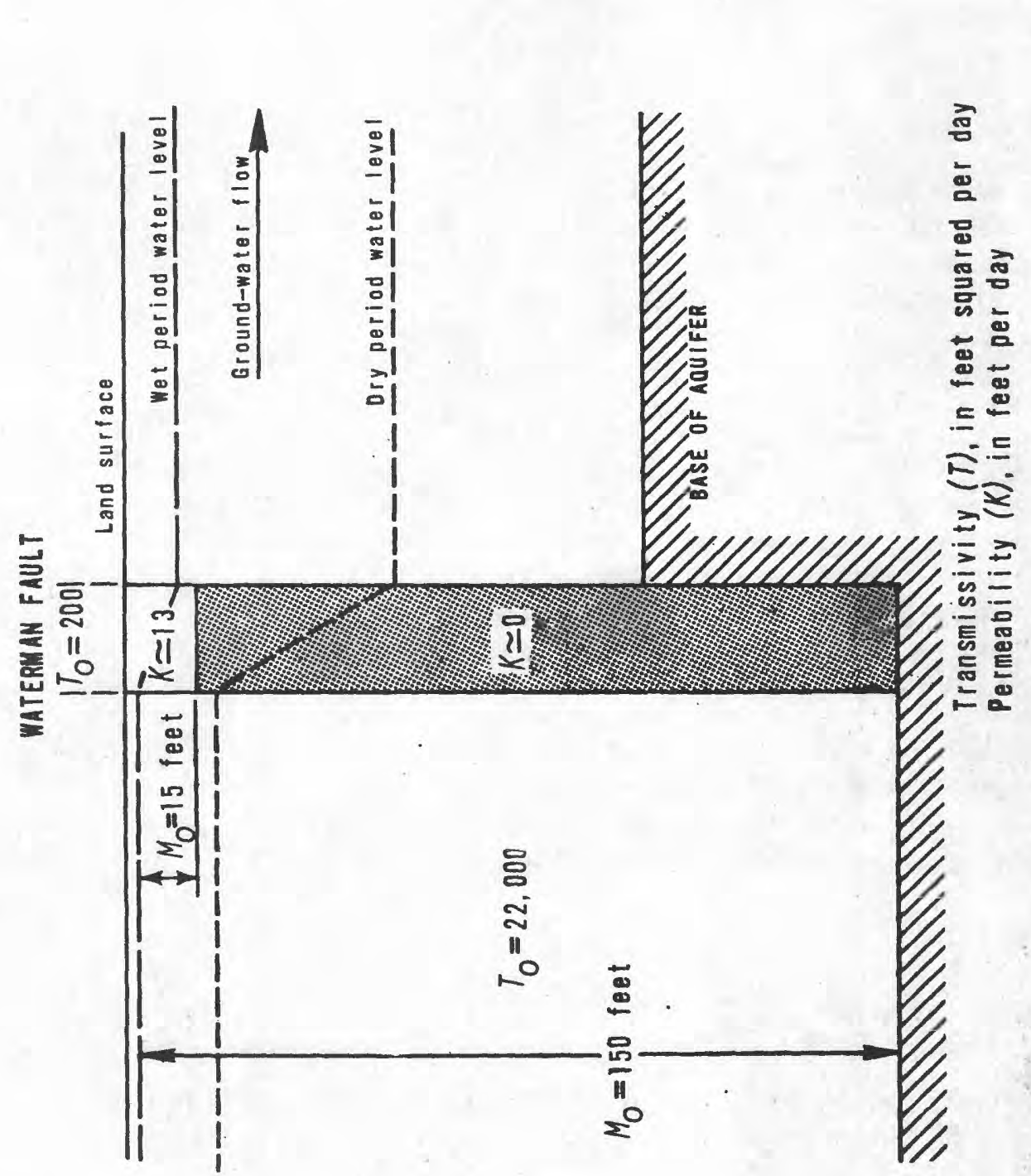

离

उ 3 क्षे की

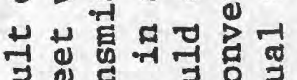

สื

4

मे

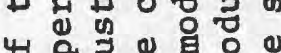

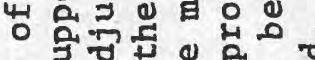

త్త

论

फे

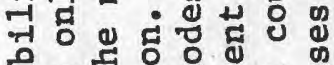

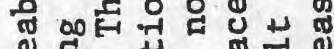

草

兵

क o 5 क व

๑ \% 요

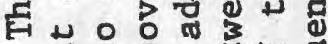

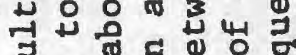
i मे

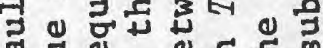

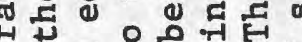
I $\rightarrow$ O ${ }^{2}$ O 0 出

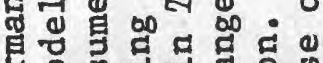

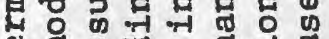

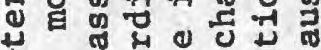

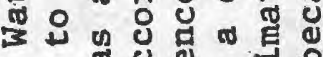

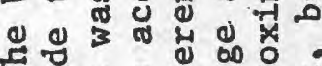

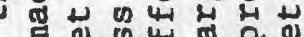
व क्ष त्रत ० 4 व चु

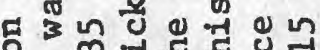
०

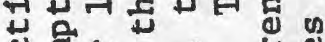
宣舟

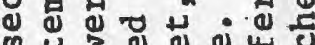
म क बन्न कु की मू

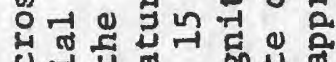
गु के क्ष

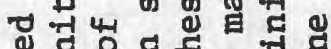
म्न न्न यु व 0 ० 0 ข नु दू

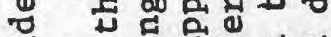

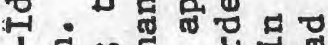

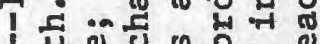
- مन क o 워요 प्ये 出

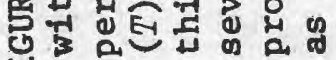
岳 


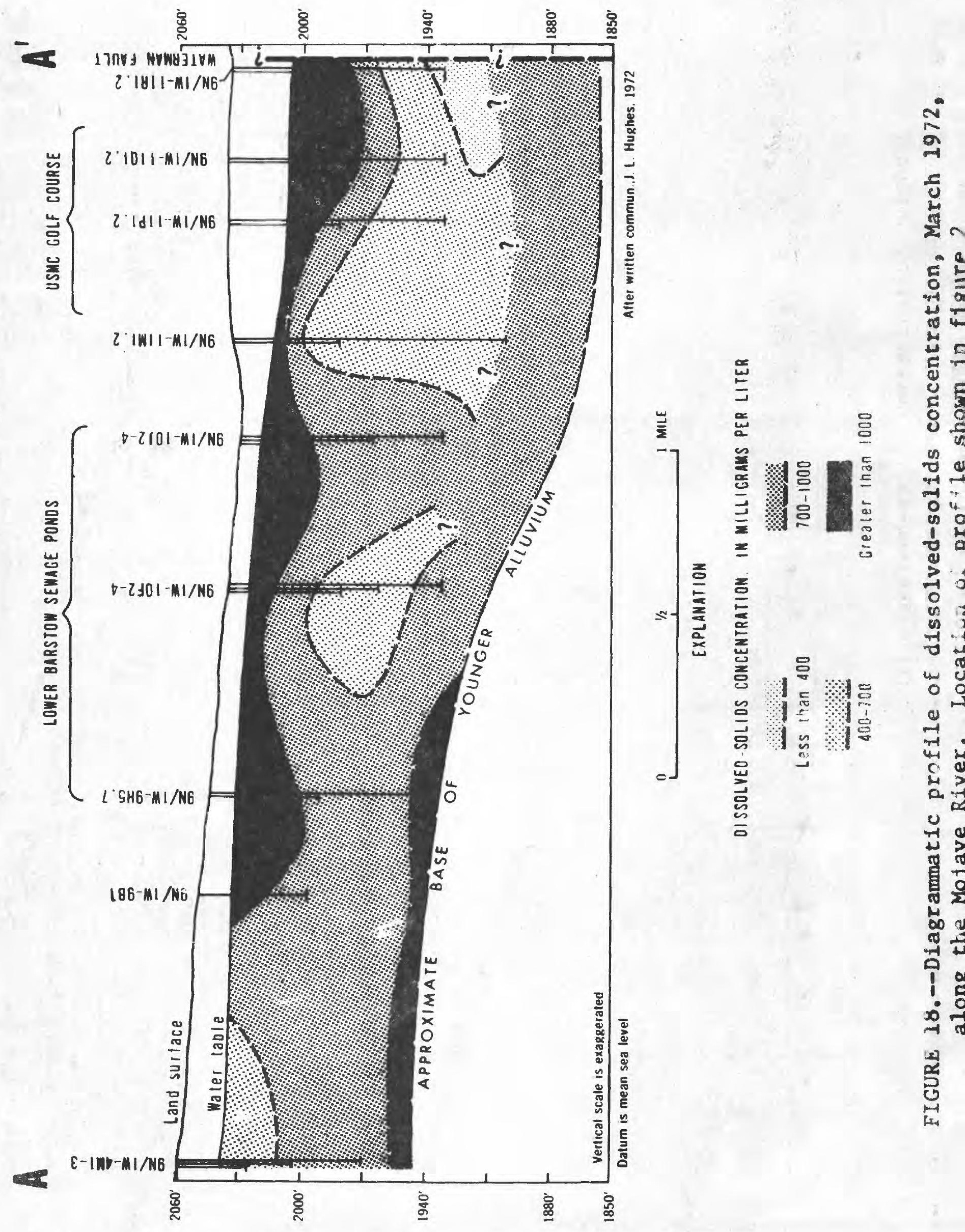


The verification of the water-quality model is based on a comparison of model-generated data and historic field data. When deviations occur between the model-generated data and the field data, it is sometimes difficult to determine if the deviations are due to improper model parameters, or are due to field data that do not accurately represent the average conditions in the aquifer. By making a series of model runs using various parameter values, it is possible to gain some insight into the reliability of the fleld data and to determine the parameter configuration that gives the best verification of the mode1. The comparisons between model-generated head and water-quality data and field data shown in figures 6 and 7 were considered adequate for the purposes of this study, and the model was considered verified.

The above problems can affect the feasibility of using the water-quality model to varying. degrees. Hydrologic conditions that would produce very abrupt changes in the saturated thickness or transmissivity of the aquifer, large head declines, or complete dewatering of parts of the aquifer can generally be foreseen before a water-quality model study is begun. Waterquality modeling may not be feasible with the existing computer program for aquifers where any of these conditions are a major factor that must be correctly simulated by the model. In other unaffected aquifers, or in aquifers where these conditions are not of major consequence, use of the water-quality model seems feasible. Other problems such as the sporadic fluctuation in the dispersion calculations and data that do not represent mean conditions in the aquifer are, at best, difficult to evaluate prior to construction of the model. That these conditions may not affect large areas of the aquifer is of some consolation when attempting to evaluate their significance.

MODEL OUTPUT

The model output is an additional factor to be taken into consideration in evaluating the applicability of the water-quality model. As an example, the water-quality model was used to calculate head and water-quality configurations for two sets of conditions--historic and future.

The model was first used to calculate the 1971 dissolved-solids concentration in the aquifer if ground-water recharge from the lower Barstow sewage ponds had never occurred (fig. 19). A second run was made to show the 1971 water-quality conditions if irrigation-return recharge had never occurred at the Marine Corps golf course (fig. 20). By comparing the mode1-generated 1971 dissolved-solids concentration map ( $f i g .21$ ) with figures 19 and 20, the degree of historic ground-water degradation produced by each of the three sources of poor-quality ground-water recharge' near the Marine Base can be seen.

The water-quality model was also used to provide better definition of the extent of the historic plume of degraded water near the upper Barstow sewage ponds. As shown in figure 22, the area of the degraded plume gradually increased from 1946 through 1968. In 1969 large quantities of good-quality 

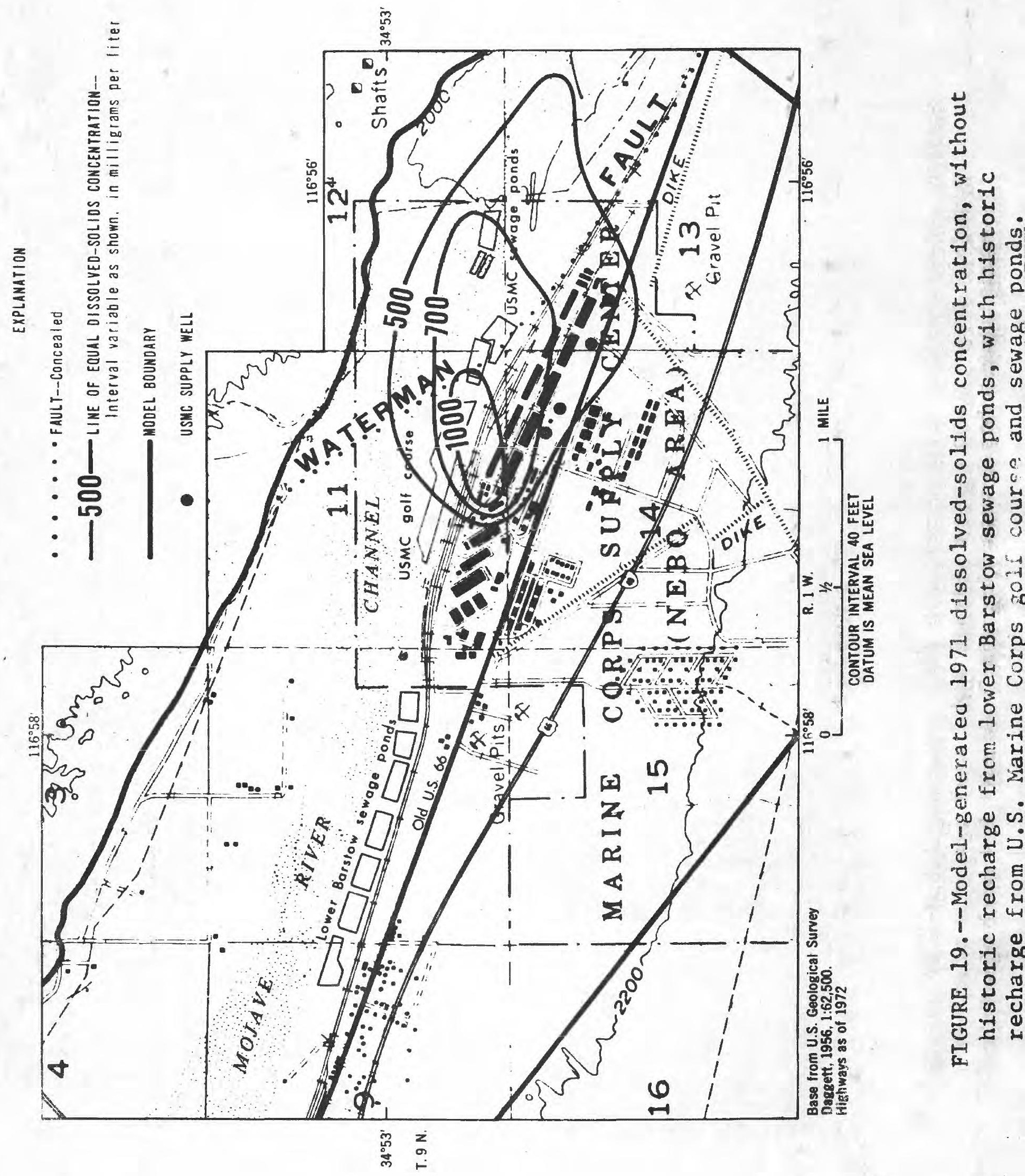


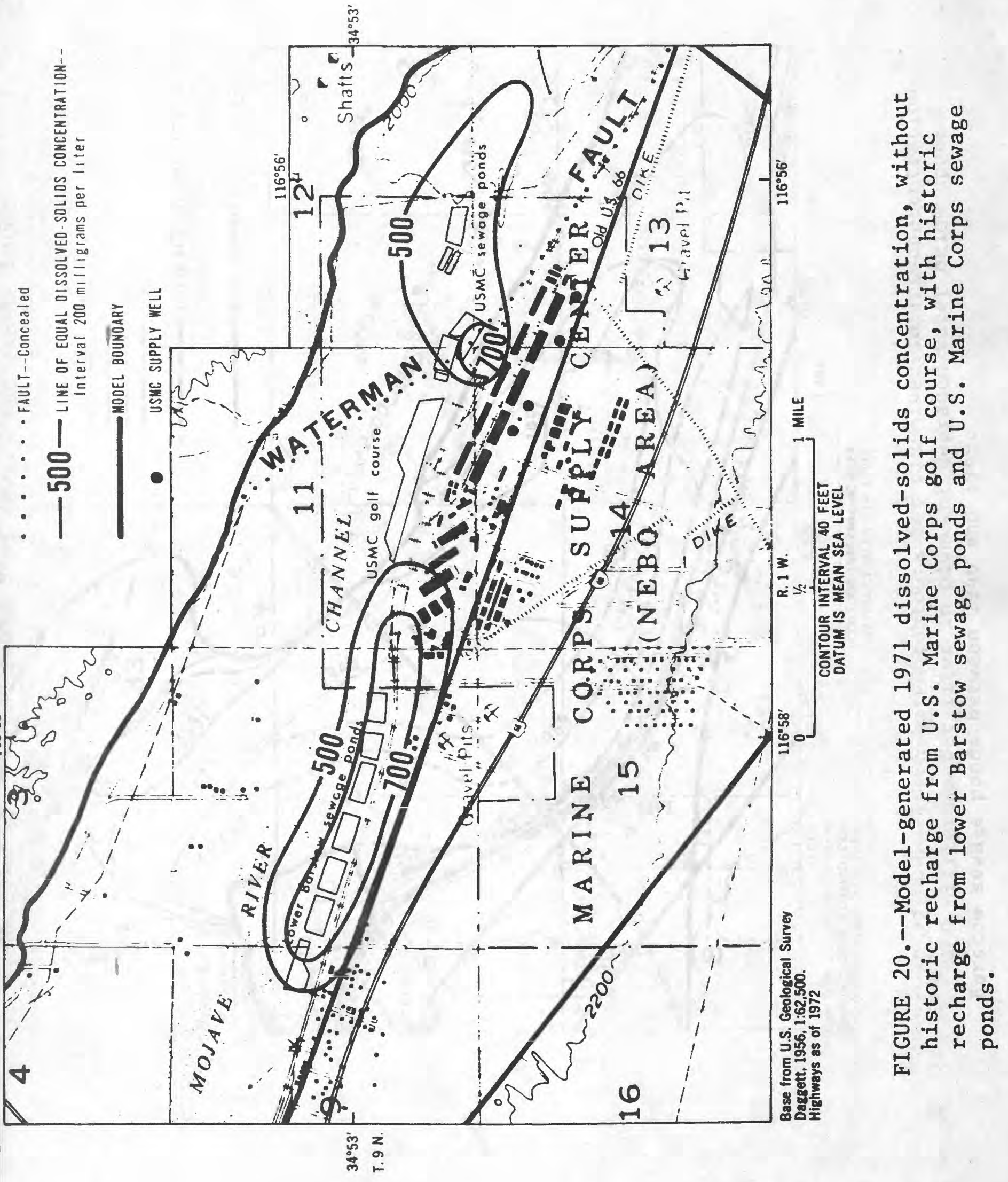




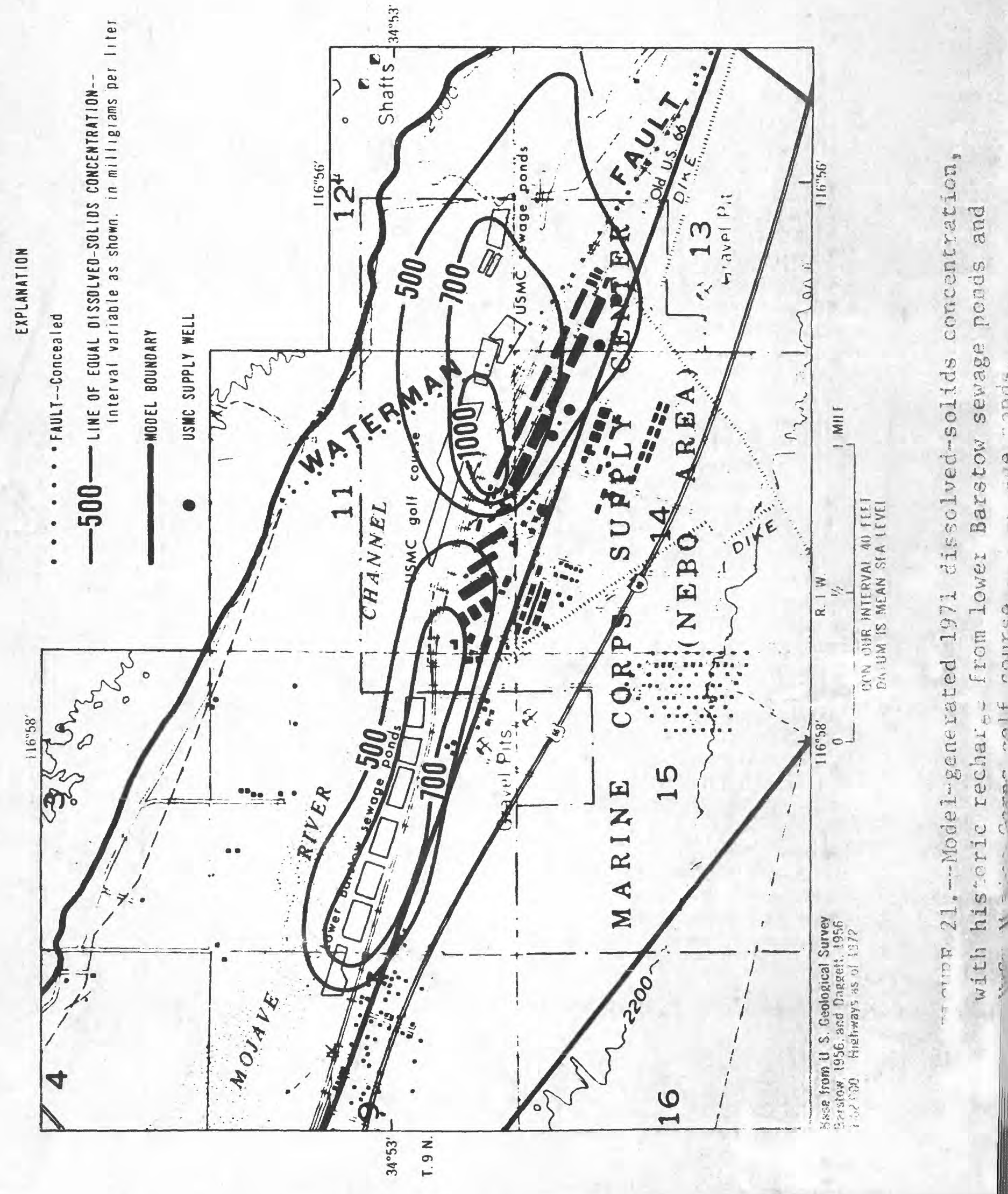



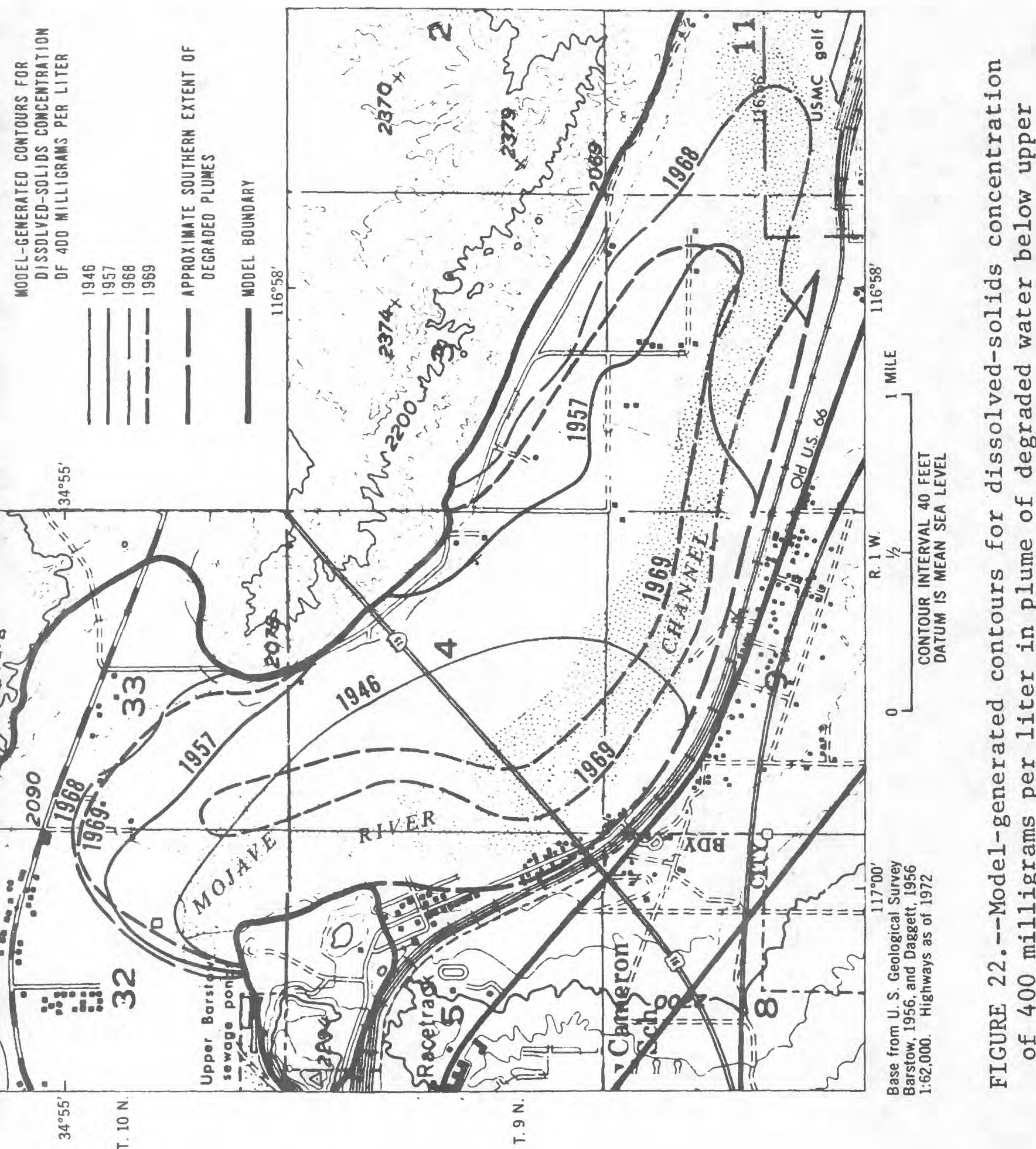

$\begin{array}{ll}0 \\ 0 \\ 0-1 & 4 \\ -1 & 4 \\ 0 & 0 \\ 0 & 3 \\ 1 & 3\end{array}$

10

$\sum_{-1}^{\infty}$

o 40

(2) \& 9

- 70

$4-1$

$\begin{array}{lll}4 & 0 \\ 0 & 0\end{array}$

क ह

금

ㄷำ

范

บ 4 㫕

$\nabla+3$

य) न्न

0

(1)

¿ व do es 0 1 E

कै

D 000

$\sum^{0}-1 / 3$

I न्म थ

1. है

ขอ

a $\rightarrow$ क E⿱ 
The Barstow water-quality model was used to project future head and water-quality changes in the aquifer near the Marine Corps Supply Center. Head and water-quality conditions for the years 1981 and 1991 are shown in the following illustrations. The first set of conditions to be evaluated was labeled run 55 and shows the changes that would occur in the aquifer if present operational practices are continued at the lower Barstow sewage pords and the Marine Corps golf course and sewage ponds. Figure 23 shows the estimated 1972 dissolved-solids configuration and serves as a basis of compartion for the future water-quality configurations. By 1981 (fig. 24) the two plumes of degraded water shown in figure 23 have merged, and by 1991 (fig. 25) water with dissolved-solids concentrations in excess of $900 \mathrm{mg} / 1 \mathrm{will}$ extend into all the Marine Corps supply wells. Model-generated head changes ranging from 20 feet of rise near the lower Barstow sewage ponds to 30 feet of decline ast: of the Waterman fault were produced by the conditions of run 55 (fig. 26).

Model run 58A shows the effects of halting the percolation of all sewage effluent by piping all effluent out of the model area. In particular, the ground-water recharge originating from the lower Barstow sewage ponds and the Marine Corps golf course and sewage ponds was eliminated from the model. This produced head declines of as much as 70 feet near the Marine Corps supply wells (fig. 27). As discussed above, large head declines invalidate the results of the chemical quality part of the water-quality model. In this case, the feasibility of eliminating the ground-water recharge from the sewage ponds and golf course can be determined on the basis of head data alone. Head declines of 70 feet in the area of the Marine Corps supply wells would greatly reduce the yield of these wells and markedly increase the pumping costs. For this reason the management practice is not entirely desirable.

Another proposed method of combating the spread of degraded ground water involved the installation of a line of protective-pumping wells below the lower Barstow sewage ponds. For this model run (run 61) these wells were pumped at a rate of 2,000 acre-feet per year, and the flow to the Marine coxps golf course and sewage ponds was diverted to the Barstow ponds, from whith percolation continued to occur. From 1972 to 1987 (fig. 28) the privectivt. pumping wells effectively halt further spreading of the degraded plume associated with the lower Barstow sewage ponds, and an improvement in ground water quality occurs near the Marine Corps sewage ponds. However, by 1991. (fig. 29) the rate of percolation from the lower Barstow sewage ponds exceeds the protective-pumping rate by about 3,600 acre-feet per year, and water in excess of $900 \mathrm{mg} / \mathrm{I}$ has begun to move past the protective-pumping weils.

Because the 1972-91 head changes in the area are modest (fig. 30), establishing a line of protective-pumping wells seems to be an effective deterrent to the ground-water degradation near the Marine Corps Supply Center. If the rate of pumping from the wells was gradually increased in response to the increasing rate of percolation from the lower Barstow sewage ponds, the effectiveness of the barrier could probably be extended beyond 1991. 
(150 mg/1 dissolved solids) surface-water recharge occurred along the Mojave River. In the model this recharge decreased the size of the 1969 plume and produced a tongue of better quality water that extended into the plume of degraded water. The line along the southwest edge of each of the plumes $1 \mathrm{~s}$ approximate because the exact location is obscured by the effects of poorquality inflow from the aquifer to the south.

Thus the model is capable of providing detailed information on the location, concentration, and rate of spread of historic plumes of degraded water. Such information could be readily related to problems in the field. This could be a valuable supplement to existing data and could provide a better basis for evaluating historic causes and effects.

Before the model can be used to project future conditions in the aquifer, it may be necessary to revise the recharge, discharge, and water-quality data to take into consideration the increasing water demands of a growing population.

1

In the Barstow water-quality model it was assumed that the population of the city of Barstow would increase at a uniform rate from 18,000 in 1970 to 45,000 in 1985 (Inerfield and Montgomery, 1971, p. VX-2) and reach 58,000 by 1992. The resulting percolation from the lower Barstow sewage ponds would total 5,300 acre-feet per year by 1992. Because of the limited quantities of ground water available within the model area, it was assumed that the future increase in water demands for the city of Barstow would be met by pumping from aquifers out of the model area or by the importation of water. With the exception of the Marine Corps wells, the 1971 pumping rate and configuration were maintained through the 21-year projection period from 1972 through 1992. The Marine Corps water demands and quantities of sewage-effluent recharge were assumed to increase at a rate of about 2 percent per year, reaching about 2,000 acre-feet per year and 750 acre-feet per year by 1992 .

Because the future occurrence of floodflow in the Mojave River cannot be predicted, it was assumed that the future surface-water recharge would occur at about the same magnitude and frequency as did the historic recharge between 1947 and 1969. Thus the floodflow recharge that occurred in 1952, 1958, and 1969 was projected to recur in 1977, 1983, and 1992. The modified rechargedischarge data were then broken into pulses similar to those shown in table 1 in order to simulate conditions between 1972 and 1992. The chemical quality of pumpage-return recharge was increased about $250 \mathrm{mg} / 1$; the quality of other water recharging the aquifer was not altered from that which occurred under historic conditions. The resulting model projections represent head and water-quality conditions that could be expected to occur in the future if the model parameters correctly describe the future stresses on the aquifer. 


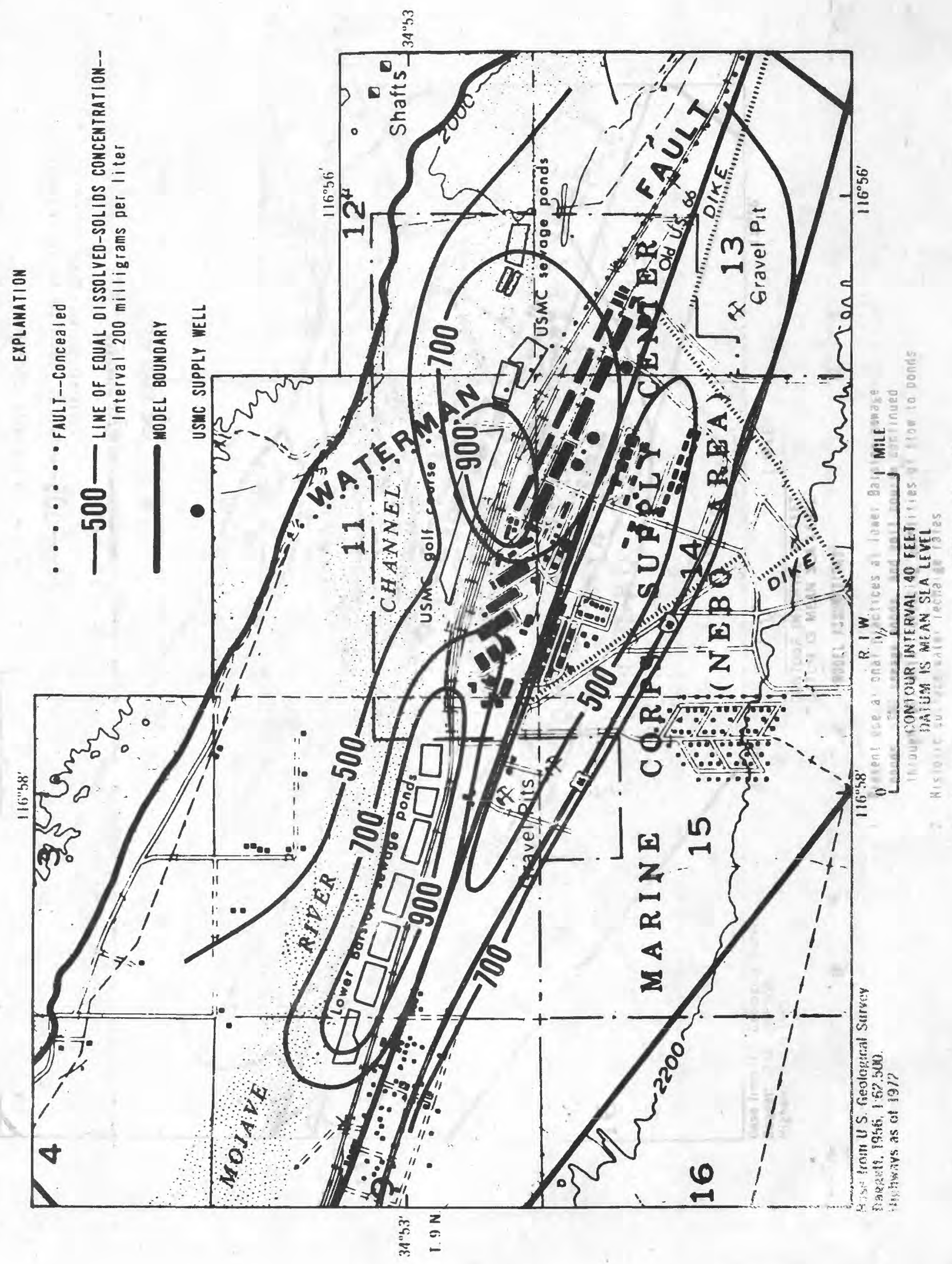




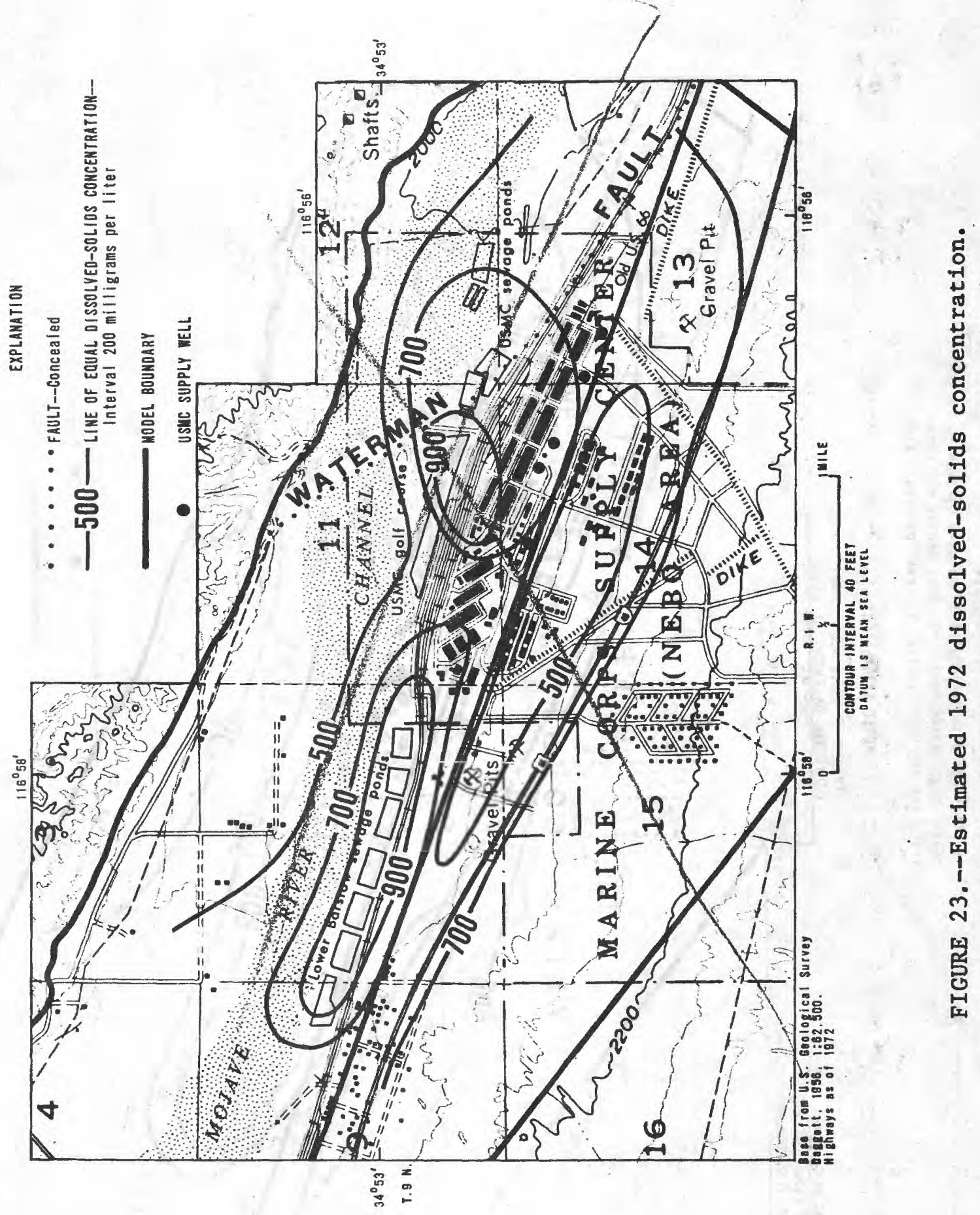




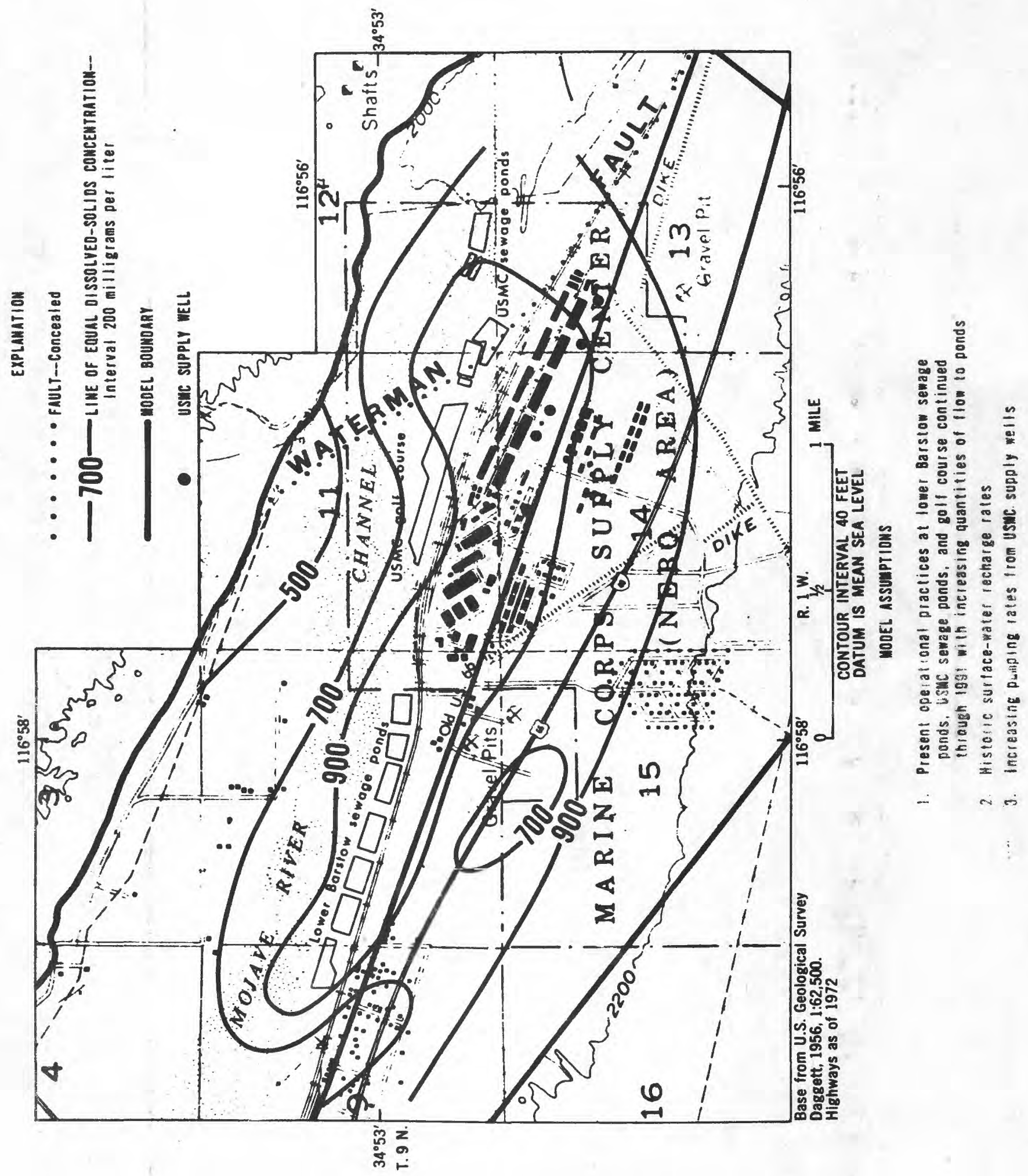




\section{7}

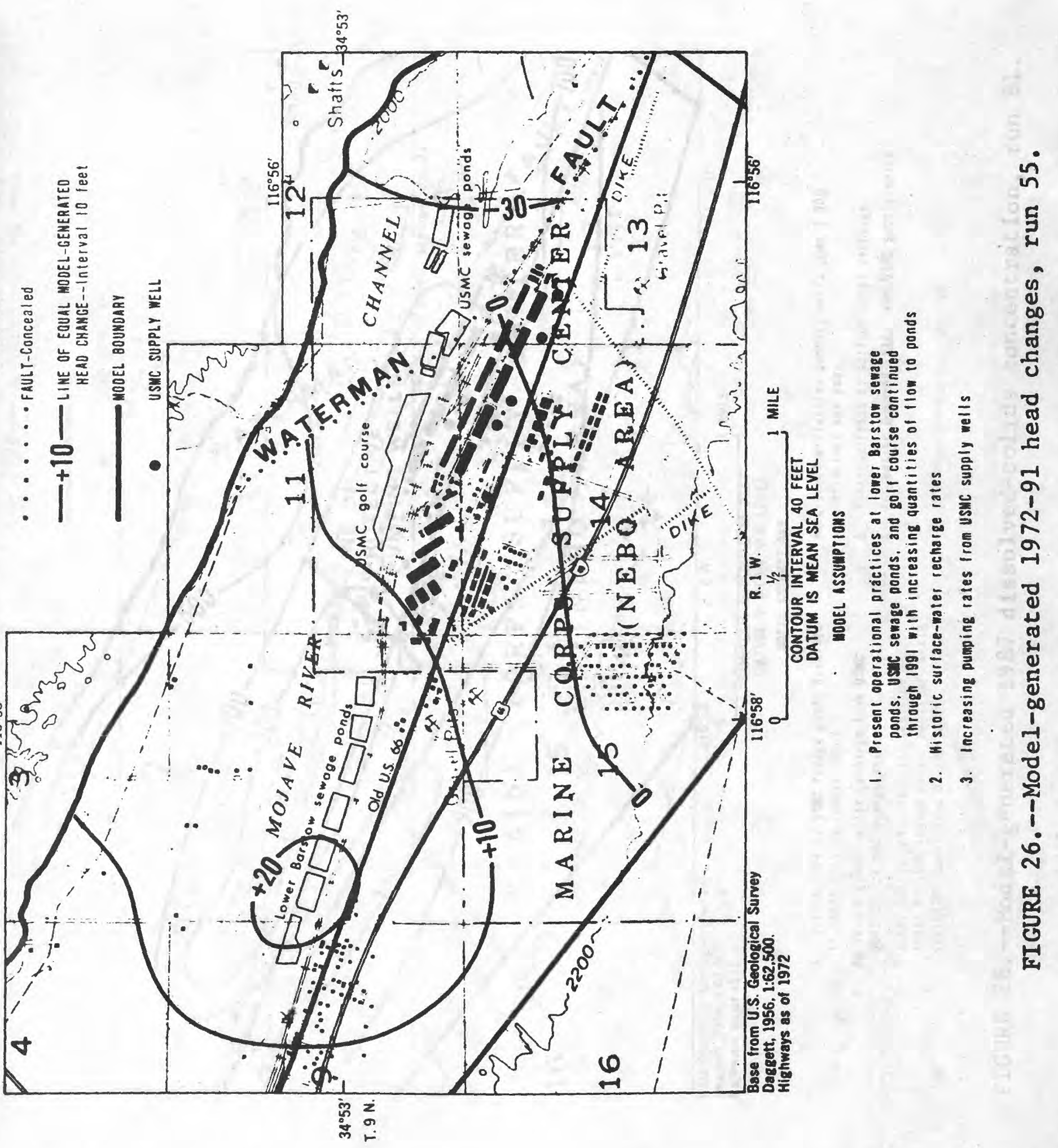




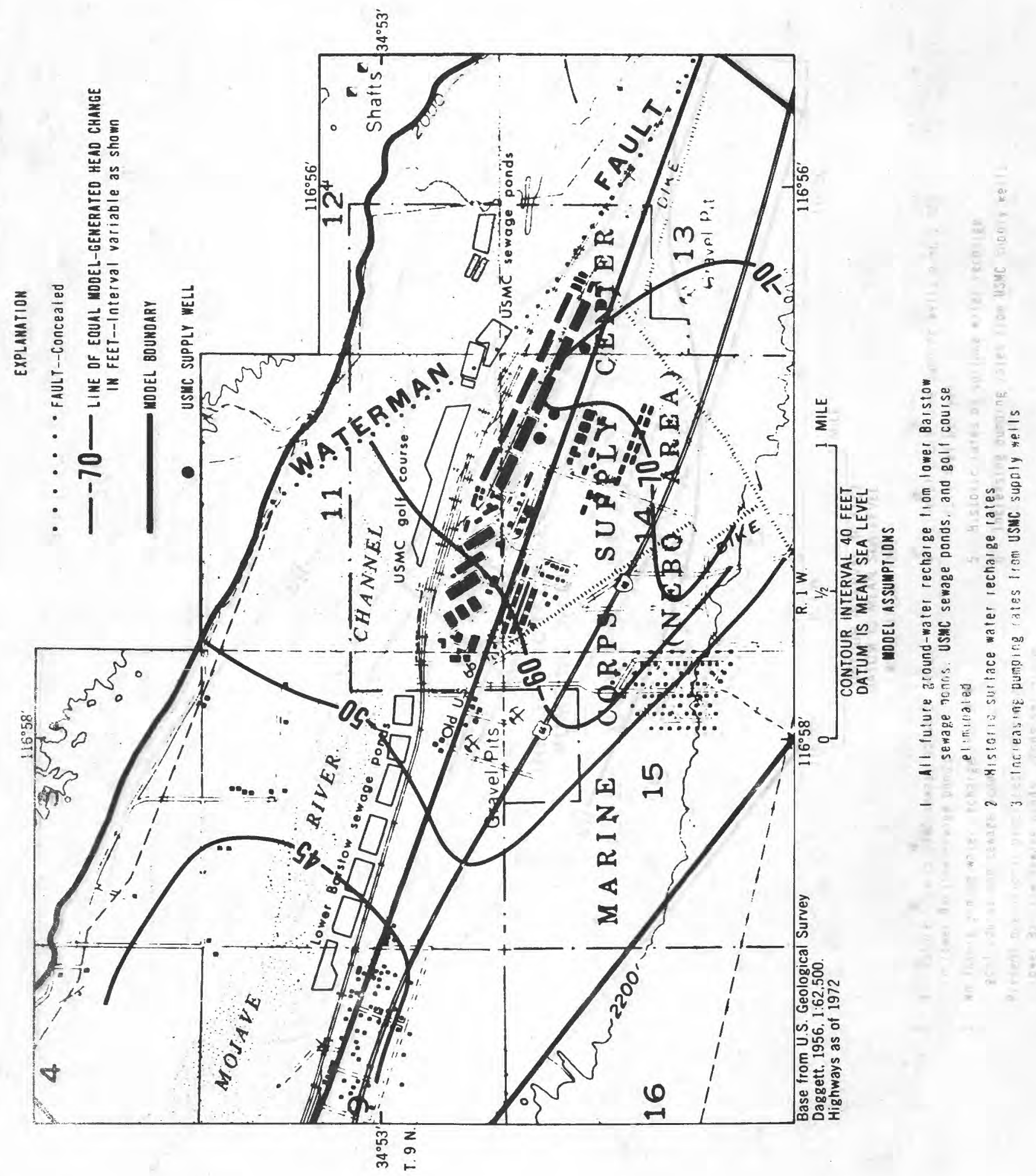




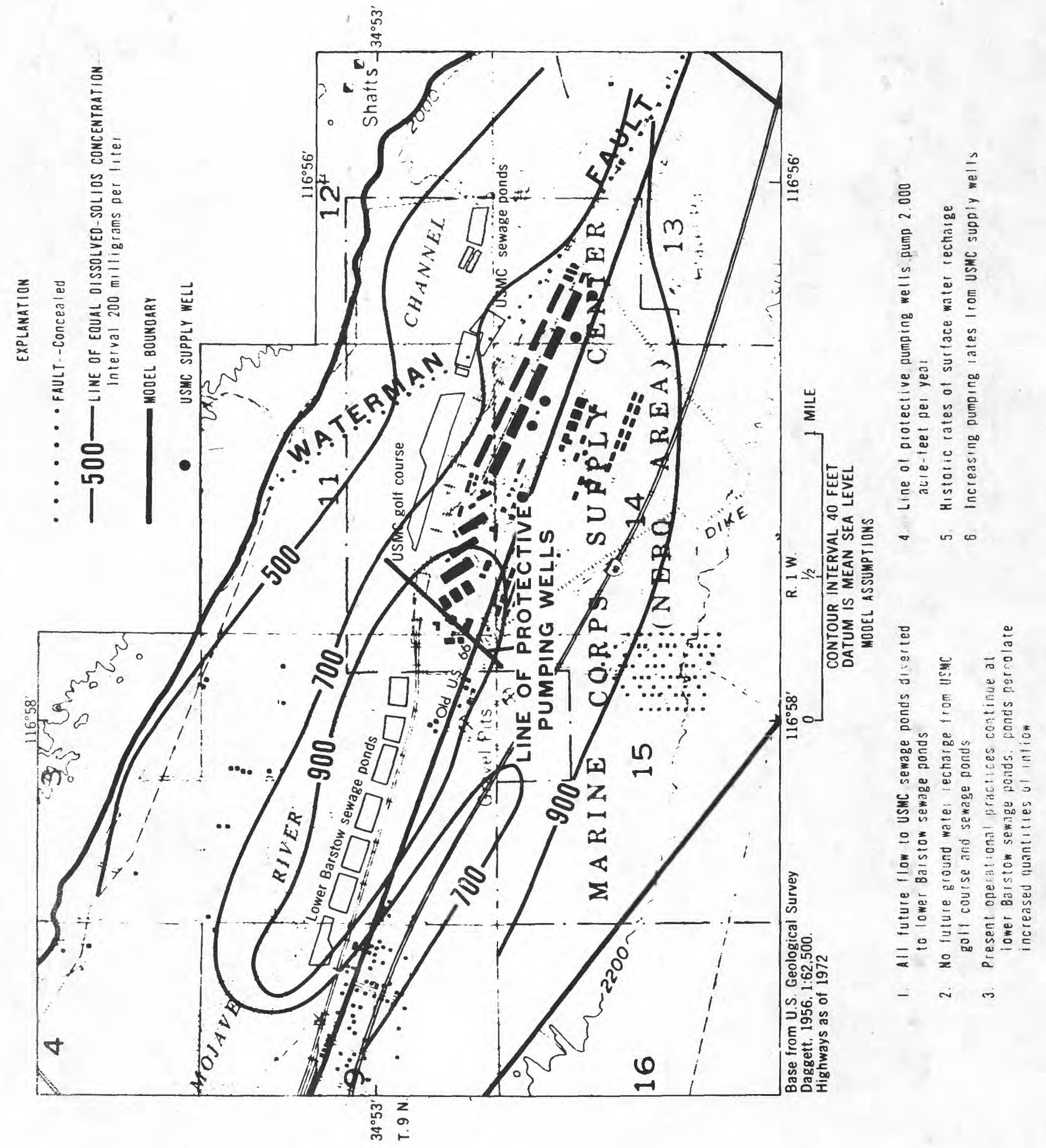




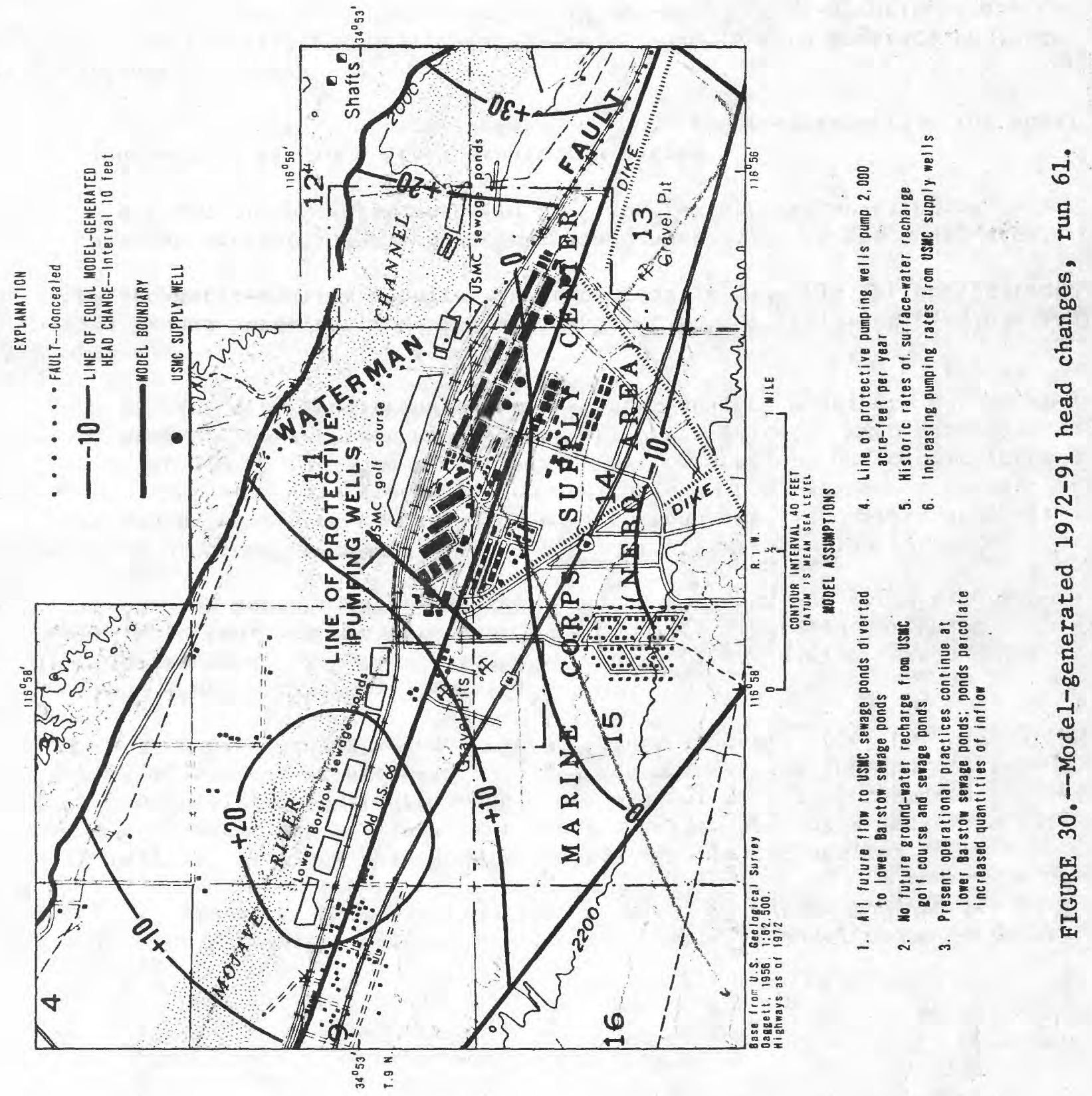


These examples indicate that the water-quality model can be an effective tool for evaluating the future hydraulic and chemical effects of ground-water utilization. In addition, the model provides a means of evaluating the effectiveness of management practices designed to combat future ground-water degradation. The model can also be effectively used to provide better definition of historic head and water-quality conditions in the aquifer and to demonstrate the cause and effect relations between historic sources of pollution and plumes of degraded ground water.

MODEL COST

Cost is also a factor in determining the feasibility of applying a waterquality model to a particular hydrologic problem. Costs can vary greatly depending on how much additional data must be collected in order to quantify the model parameters. When existing data are not available for some parameters, the project may include such items as test-well drilling, pump tests, and programs of well canvassing, sampling, and measuring. The project must also allow time to verify and interrogate the model, which may be a significant part of a complex study. The quantitative breakdown of this portion of the project costs can best be made at the local level and is not attempted here.

Computer costs vary mainly as a function of the number of nodes in the model area, the number of iterations required for head convergence, the number of times the mathematical water-quality particles must be moved, and the number of time steps in the simulation period. An increase in any of these factors requires more computer time, thereby increasing the cost of the model. run. It is not possible to determine the magnitude of all these factors prior to construction of a model. As a result, it is difficult to predict the probable cost of running the water-quality model. A comparison of two of the water-quality models used in this report gives a general indication of iuw the computer time varies with different models. In the large-scale water-quality model, there were 358 nodes in the model area, and 21 time steps were used. This required about 7.5 minutes of CPU time on the Geological Survey IBM 360-65 computer. In the smaller water-quality model of the dispersion test site there were 25 nodes in the model area, and four time steps were used. This required about 1 minute of CPU time.

The cost of a water-quality model is not inherently high. If adequace basic data are available and a small number of model nodes is satisfactory, a water-quality model can be constructed with minimal cost. Though the model costs can be nominal, the ultimate economic feasibility of applying the model to a hydrologic problem must be weighed against the benefits to be realized from the study. 


\section{CONCLUS IONS}

As a result of this study the following conclusions have been reached:

1. It is probably not feasible to run two-well tracer-dilution tests to determine dispersivity for use in water-quality models with moderate to large grid intervals because:

a. The larger the grid interval becomes the less sensitive the model is to dispersivity within a given simulation period.

b. The dispersivity measured in a small-scale tracer-dilution test may not be representative of the large-scale dispersivity of the model area.

2. The water-quality modeling is conditionally feasible for application to varied ground-water quality problems, subject to the following findings and limitations:

a. The data requirements for the water-quality model are not excessive in terms of the accuracy or quantity of data required. Much data may already be available for some areas as a result of previous hydrologic investigations. Data that are generally not available such as dispersivity and porosity may be estimated by use of model interrogation, laboratory analysis of sediment samples, or if applicable by use of tracer-dilution tests.

b. The present water-quality model is not feasible for application to water-table aquifers where intermittent complete dewatering or major changes in transmissivity or saturated thickness of the aquifer are a major factor that must be rigorously modeled.

c. A water-quality model can be a very effective tool for evaluating the future effects of ground-water utilization and degradation and provides a means of evaluating the effectiveness of management practices designed to combat ground-water degradation. The model can also provide a better definition of historic head and water-quality conditions in the aquifer.

d. The costs of a water-quality model study can be nominal if adequate basic data are available and a small number of model nodes is used. 


\section{SELECTED REFERENCES}

Bredehoeft, J. D., and Pinder, G. F., 1973, Mass transport in flowing ground water: Water Resources Research, v. 9, no. 1, p. 194-210.

Bruch, J. C., Jr., 1970, Two-dimensional dispersion experiments in a porous medium: Water Resources Research, v. 6, no. 3, p. 791-800.

Garder, A. O., Jr., Peaceman, D. W., and Pozz1, A. L., Jr., 1964, Numerical calculation of multidimensional miscible displacement by the method of characteristics: Jour. Soc. Petroleum Engineers, v. 4, no. 1, p. 26-36.

Grove, D. B., 1971, U.S. Geological Survey tracer study, Amargosa Desert, Nye County, Nevada; Part 2: An analysis of the flowfield of a discharging-recharging pair of wells: U.S. Geol. Survey Water-Resources Inv. 474-99, 56 p.; available only from U.S. Dept. Commerce, Nat1. Tech. Inf. Service, Springfield, Va. 22151.

Grove, D. B., and Beetam, W. A., 1971, Porosity and dispersion constant calculations for a fractured carbonate aquifer using the two-well tracer method: Water Resources Research, v. 7, no. 1, p. 128-134.

Hardt, W. F., 1969, Mojave River basin ground-water recharge with particular reference to the California floods of January and February 1969: U.S. Geol. Survey open-file rept., $13 \mathrm{p}$.

1971, Hydrologic analysis of Mojave River basin, California, using electric analog model: U.S. Geol. Survey open-file rept., 84 p.

Harloman, D. R. F., and Rumer, R. R., 1963, Longltudinal and lateral dispersion in an isotropic porous medium: Jour. Fluid Mechanics, v. 16, pt. 3, p. 385-394.

Inerfield, A. J., and Montgomery, J. M., 1971, City of Barstow final report on waste-treatment facilities: Arthur J. Inerfield \& Associates, Burlingame, Calif., 47 p.

Koehler, J. H., 1970, Water resources at Marine Corps Supply Center, Barstow, California, for the 1969 fiscal year: U.S. Geol. Survey open-file rept., $22 \mathrm{p}$.

1972, Water resources at Marine Corps Supply Center, Barstow, California, for the 1971 fiscal year: U.S. Geol. Survey open-file rept., 18 p.

Miller, G. A., 1969, Water resources of the Marine Corps Supply Center area, Barstow, California: U.S. Geol. Survey open-file rept., 51 p. 
Pinder, G. F., and Bredehoeft, J. D., 1968, Application of the digital computer for aquifer evaluation: Water Resources Research, v. 4, no. 5, p. 1069-1093.

Redde11, D. L., and Sunada, D. K., 1970, Numerical simulation of dispersion in ground-water aquifers: Colorado State Univ. Hydrology Paper no. 41, 79 p.

Todd, D. K., 1967, Ground-water hydrology: New York, John Wiley and Sons, Inc., $336 \mathrm{p}$.

Webster, D. S., Proctor, J. F., and Marine, I. W., 1970, Two-wel1 tracer test in fractured crystalline rock: U.S. Geol. Survey Water-Supply

Paper 1544-I, 22 p.

Wilson, L. G., 1971, Investigations on the subsurface disposal of waste effluents at inland sites: U.S. Dept. Interior, Research and Development Progress Rept. no. 650, 106 p. 

APPENDIX 

The steady-state water-quality model is based on a modified version of a transient-state hydraulic model program written by G. F. Pinder. The program simulates steady-state head and water-quality conditions in a confined or unconfined aquifer with irregular boundaries, vertical leakage, and nonhomogeneous transmissivity. The effects of dispersion are not considered in the modeh. The program is dimensioned to use a 50 by 50 node array but can be modified to use larger arrays if needed.

The model requires three types of hydrologic data: a transmissivity map of the aquifer, the location and quantity of recharge and discharge entering and leaving the aquifer, and the chemical quality of the water recharging the aquifer. A conservative chemical constituent such as chloride or dissolved solids may be used as the modeled water-quality parameter. The recharge and discharge rates must be equal and of opposite sign, with negative signifying ground-water recharge and positive signifying ground-water discharge. The hydraulic part of the program calculates in units of feet and seconds so the recharge-discharge and $\mathrm{T}$ data must either be entered in these units or converted to these units by use of the conversion factors FACT and FACR. Any convenient units of chemical concentration may be used.

If the model solution does not converge, the message "EXCEEDED PERMITTED NUMBER OF ITERATIONS" is printed. This problem can usually be corrected by increasing the number of iteration parameters (LENGTH); three to nine are. usually sufficient. If a node in the model area has no inflow the message "CAUTION, ANOMALY AT NODE---" is written. The model automatically Inserts a concentration of unity at this node, and the correct concentration must be manually inserted before the punched deck is used as an initial concentration array in a non-steady-state model. 


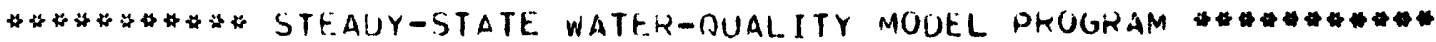

THE FOLLOWING PARAMETERS ARE DEFINED ON THE PARAMETER CARDS

PARAMETERS PRECEDED GY * ARE TNTEGER, ALL OTHERS ARE REAL

* Diml NUMBER UF nODEs IN a COLUMN OF THE MATRIX

- DIMW Number OF NODEs IN a ROW OF THE MATRIX

- LENGTH nUMBER OF ITERATION PARAMETERS

QRE RATE OF CONSTANT VERTICAL LEAKAGE PER SOUARE.

FOOT OF MODEL AREA FT**3/SEC/FT**2

ERR ERROR CRITERIA FOR CONVERGENCE

FACT MULTIPLIER FOR TRANSMISSIVITY DATA

FACR MULTIPLIER FOR RECHARGE - DISCHARGE DATA

CENTH ELEVATION OF WATER LEVEL NEAR CENTER OF MODEL AREA

QREQW CHEM OUALITY OF VERTICAL LEAKAGE

- PNCH INDICATOR FOR PUNCHED OUTPUT OF WATER QUAL \& HEAD

1 FOR PUNCHED OUTPUT O FOR NO PUNCHED OUTPUT

* contR indicator for cONTOURED PRINT OUT Of head

I FOR CONTOURED OUTPUT O FOR No CONTOURED OUTPUT

- NUM INOICATOR FOR NUMERICAL PRINT OUT OF HEAD

- I for numerical output o for no numerical output

- PRMTR INDICATOR FOR INPUT DATA PRINT OUT

1 FOR PRINT OUT O FOR NO PRINT OUT

FIVE DATA SETS ARE REQUIRED

DATA SET\#I GRID INTERVAL IN X DIRECTION

\# 2 GRID INTERVAL IN Y DIRECTION

\# 3 RATE MATRIX - = RECHARGE + = DISCHARGE

\#4 T MATRIX

\#5 CHEMICAL QUALITY OF RECHAKGE WATER

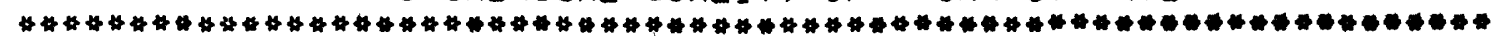

DIMENSION RATE $(50,50), \operatorname{KEEP}(50,50), G(50)$, TEMP $(50)$, BE $(50), R H O P($ $125)$, STRT $(50,50), T(50,50)$, PHI $(50,50)$, DELX $(50)$, UELY $(50)$, GRAPHI $250), C(50,50), \operatorname{CON}(50,50), I C O N(50)$

REAL $8 K$

INTEGER DIML, DIMW, PNCH, CONTR, NUM, TEST, PRMTR, ORAWD , GRAPH

DOUBLE PRECISION PHI,KEEP,D,G,TEMP,BE,W,TI,T2,T3,T4,IMK,A,B,CC,DEL

$1 T$, RHOP,PARAM

DELT $=31557600000$

NUMT $=4$

KTH $=4$

TMAX $=900000000$.

SUM $=0.0$

$\mathrm{C}$
$\mathrm{C}$
$\mathrm{C}$

READ IN DATA

READ $(5,66)$ DIML, DIMW, LENGTH, QRE, ERR, FACT, FACR, CENTH, QREOW

READ $(5,72)$ PNCH, CONTR, NUM, PRMTR

READ $(5,75) \quad$ (DEL X (J),J $=1, D I M W)$

REAU $(5,75)$ (DELY (I), I =1,OIML)

DO $1 \mathrm{I}=1,0 \mathrm{IML}$

DO $1 \mathrm{~J}=1, D I \mathrm{MW}$

$\operatorname{STRT}(I, J)=0.0$

$\operatorname{CUN}(I, J)=0.0$

$C(I, J)=0.0$

$1 \operatorname{PHI}(I, J)=0.0$

DO 2 I $=1, D I M L$

2 READ $(5,67)$ (RATE $(I, J), J=1, D I M W)$

DO 3 I $=1$, DIML

READ $(5,67)(T(I, J), J=1, D I M W)$ 


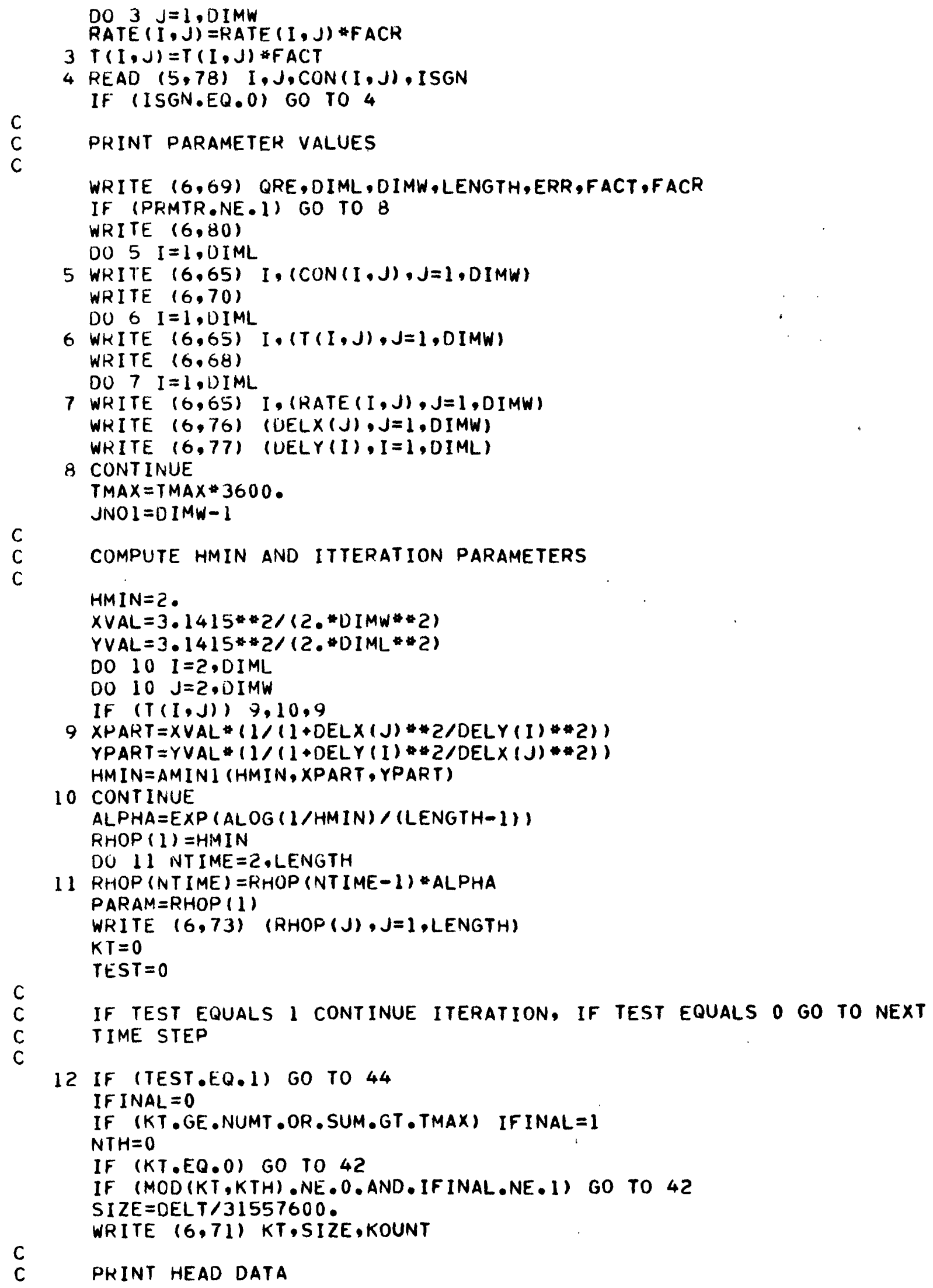


C

IF (NUM.NE.1) GO TO 14

WRITE $(6,64)$

DO $13 \quad I=1,0 I M L$

13 WKITE $(6,65) \mathrm{I},(\mathrm{PHI}(I, J), J=1, D I M W)$

14 CONTINUE

IF (CONTR.NE.1) GO TO 23

ICEN $=0$

WRITE $(6,63)$

DO 22 IB $=1, D I M L$

DO $21 \mathrm{JB}=1, \mathrm{DIMW}$

IF $(T(I B, J B)) 15,15,17$

$15 \operatorname{GRAPH}(J B)=-1$

GO TO 21

17 DRAWD = IDINT $($ PHI $(I B, J B)+C E N T H+0.5)-I C E N$

IF (DRAWD.LT.O) GO TO 19

IF (DRAWD.GT.999) GO TO 18

GO TO 20

18 ICEN $=$ ICEN +1000

GO TO 17

19 ICEN $=$ ICEN -1000

GO TO 17

$20 \operatorname{GRAPH}(J B)=$ ORAWD

21 CONTINUE

WRITE $(6,62) \quad($ GRAPH $(J B), J B=2, D I M W)$

22 CONTINUE

C

23 IF (IF INAL.NE. 1) GO TO 42

C

C

COMPUTE WATER QUALITY CONFIGURATION

IMONE $=D I M L-1$

$J M O N E=D I M W-1$

NTMS $=0$

24 KTST $=0$

NTMS $=$ NTMS +1

IF (NTMS.GT.20) GO TO 37

DO $36 \quad I=2$, IMONE

DO $36 \mathrm{~J}=2$, JMONE

IF $(T(1, J), E Q .0 .0)$ GO TO 36

IF $(C(1, J), G T, 0.0)$ GO TO 36

SSUM $=0.0$

$Q 1=0.0$

$Q 2=0.0$

$Q 3=0.0$

Q4 $=0.0$

$C Q 1=0.0$

$C Q 2=0.0$

$\cos 3=0.0$

$C Q 4=0.0$

CU5 $=0.0$

IF $(T(I, J-1), E Q, n, 0)$ GO TO 26

If $(P H I(I, J-1)-P H I(I, J)) \quad 26,26,25$

25 IF $(C(I, J-1)$ LLE.0.0) GO TO 35

$T I=(2, * T(I, J-1) * T(I, J)) /(T(I, J-1)+T(I, J))$

$Q I=T 1 * 2 . *(P H I(I, J-1)-P H I(I, J)) * \operatorname{DELY}(I)>(\operatorname{DELX}(J-1)+\operatorname{DELX}(J))$

$C Q 1=C(I, J-1) * Q 1$

$S S U M=S S U M+Q 1$

26 IF $(T(I, J+1), E Q, 0.0)$ GO TO 28

IF $(P H I(I, J+I)-P H I(I, J)) \quad 28,28,27$ 
27 IF $(C(I, J+1) . L E, 0.0)$ GO TO 35

$T S=(2 . * T(I, J+1) * T(I, J)) /(T(I, J+I)+T(I, J))$

$Q 2=T 2 * 2 . *(P H I(I, J+1)-P H I(I, J)) * n E L Y(I) / \operatorname{DEL} X(J+1) \bullet \operatorname{DEL} X(J))$

$C(12=C(1, J+1) * Q 2$

$S S U M=S S U M+Q 2$

28 IF $(T(I-1, J), E Q .0 .0)$ GO TO 30

IF $(P H I(I-I, J)-P H I(I, J)) 30,30,29$

29 If $(C(I-1, J), L E, 0.0)$ GO TO 35

$T 3=(2 . T(I-1, J) * T(I, J)) /(T(I-1, J)+T(I, J))$

$Q 3=T 3 * 2$ * $($ PHI $(I-1, J)-P H I(I, J)) * \operatorname{NELX}(J) /(\operatorname{DELY}(I-1)+\operatorname{DELY}(I))$

$C(13=C(I-1, J) * 03$

SSUM $=S S U M+03$

30 IF $(T(I+1, J), E O, 0.0)$ GO TO 32

IF $(P H I(I+I, J)-P H I(I, J)) 32,32,31$

31 IF $(C(I+1, J), L E, 0.0)$ GO TO 35

$T 4=(2, * T(I+1, J) * T(I, J)) /(T(I+1, J)+T(I, J))$

$Q 4=T 4 * 2 . *(\operatorname{PHI}(I+1, J)-\operatorname{PHI}(I, J)) \otimes D E L X(J) / \operatorname{DELY}(I+1)+\operatorname{DEL} \cdot Y(I))$

$C Q 4=C(I+1, J) * Q 4$

SSUM $=$ SSUM +04

32 IF (RATE $(I, J), G E, 0.0)$ GO TO 33

RATN $=R A T E(I, J) *(-1.0)$

CQS $=R A T N * C O N(I, J)$

$S S U M=S S U M+R A T N$

33 IF (ORE.LE.0.0) GO TO 90

RQRE $=O R E$ DELX (J) OELY (I)

$C Q 5=C Q 5+R Q R E * O R E Q W$

$S S U M=S S U M+R Q R E$

90 IF (SSUM.NE.0.0) GO TO 34

$C(I, J)=1.0$

WRITE $(6,81)$ I, J

GO TO 36

$34 \mathrm{C}(I, J)=(\mathrm{CO} 1+\mathrm{CQ} 2+\mathrm{CQ} 3+\mathrm{CQ} 4+\mathrm{CQ} 5) / \mathrm{SSUM}$

GO TO 36

35 KTST $=1$

36 CONTINUE

IF (KTST.EQ.1) GO TO 24

C

C

C

PRINT WATER QUALITY DATA

WRITE $(6,79)$

37 CONTINUE

DO $38 \quad I=1,0 I M L$

38 WRITE $(6,65) \mathrm{I},(C(I, J), J=1,0 \mathrm{IMW})$

IF (CONTR.NE.1) GO TO 92

JCEN $=0$

WRITE $(6,79)$

DO 84 I $B=1$, DIML

$\mathrm{DO} 91 \mathrm{JB}=1,0 \mathrm{IMW}$

If $(T(I B, J B)) 85,85,86$

$85 \operatorname{GRAPH}(J B)=-1$

GO TO 91

86 DRAWD $=$ INT $(C(I B, J B)+0.5)-J C E N$

IF (DRAWO.LT.0) GO TO 87

IF (DRAWD.GT.999) GO TO 88

GO TO 89

$88 J C E N=J C E N+1000$

GO TO 86

87 JCEN $=J C E N-1000$

GO TO 86 
$89 \operatorname{GRAPH}(J B)=$ DRAWD

91 CONTINUE

WRITE $(6,62)$ (GRAPH ( JB), JB =2, DIMW)

84 CONTINUE

92 IF (PNCH.NE.1) STOP

39 DO $40 \quad I=1,0 I M L$

DO $83 \mathrm{~J}=1,0 \mathrm{IMW}$

$\operatorname{ICON}(J)=C(I, J)+0.5$

83 CONTINUE

40 WRITE $(7,82)(I \operatorname{CON}(J), J=1, D I M W)$

DO $41 \quad I=1$, DIML

41 WRITE $(7,67)$ (PHI $(I, J), J=1, D I M W)$

STOP

42 CONTINUE

$K T=K T+1$

KOUNT $=0$

DO $43 \quad I=1,01 M L$

DO $43 \mathrm{~J}=1$, OIMW

$\operatorname{KEEP}(I, J)=\operatorname{PHI}(I, J)$

43 CONT INUE

DELT $=D E L T+D E L T$

$S U M=S U M+D E L T$

GO TO 46

44 IF (KOUNT.LT.200) GO TO 45

WRITE $(6,74)$

GO TO 39

45 KOUNT $=$ KOUNT +1

IF (MOD (KOUNT, LENGTH)) $46,46,47$

46 NTH $=0$

$47 \mathrm{NTH}=\mathrm{NTH}+1$

PARAM $=$ RHOP $(N T H)$

TEST $=0$.

DO $48 \mathrm{~J}=1$, DIMW

$48 \operatorname{TEMP}(J)=P H I(1, J)$

DO $54 \quad I=2,0 I M L$

DO $50 \mathrm{~J}=2, \mathrm{JNO} 1$

IF $(T(I, J)) 49,50,49$

$\mathrm{C}$

49 CONTINUE

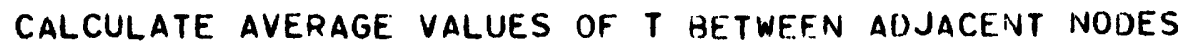

C

NODE CONFIGURATION TI=LEFT, TZ=RIGHT, T3=UPPEK, T4=LOWER

$T 1=((2, * T(1, J-1) * T(1, J)) /(T(I, J) * D E L X(J-1)+T(I, J-1) * \operatorname{OELX}(J))) / D E L X$ $1(\mathrm{~J})$

$T 2=((2 * * T(I, J+I) * T(I, J)) /(T(I, J) * D E L X(J+1)+T(I, J+1) * D E L X(J)) / / D E L X$ $1(\mathrm{~J})$

$T 3=((2 * T(I-1, J) * T(I, J)) /(T(I, J) * \operatorname{DEL} Y(I-1)+T(I-1, J) * \operatorname{DELY}(I))) / D E L Y$

$1(\mathrm{I})$

$T 4=((\varepsilon, * T(I+1, J) * T(I, J)) /(T(I, J) * D E L Y(I+1)+T(I+1, J) * \operatorname{DEL} Y(I))) / D E L Y$

I(I)

$I M K=P A R A M *(T I+T \geq+T 3+T 4)$

$K=0.0$

C

C

CALCULATE VALUES FOR PARAMETERS $A, B, C$, AND BE

$B=-T 1-T 2-K-I M K$

$A=T 1$

$C C=T 2$

$W=B-A * B E(J-1)$ 
$\operatorname{BE}(J)=C C / W$

CHECK NODE FOR POSSIBLE WELL LOCATION

$R R=Q R E$

$R W=0.0$

RW=RATE $(I, J) /(D E L X(J) * D E L Y(I))$

$D=-T 3 * P H I(I-I, J)+(T 4+T 3-I M K) * P H I(I, J)-T 4 * P H I(I+1, J)+R W-R R$

50 CONT INUE

$G(J)=(D-A * G(J-1)) / W$

CALCULATE HEAD VALUES FOR ROWS OF MATRIX AND PLACE THEM IN TEMPORARY LOCATION TEMP

NO3 $=0$ I MW -2

0053 KNO4 $=1, \mathrm{NO}_{3}$

NO4=DIMN-KNO4

PHI $(I-1, N 04)=$ TEMP (NO4)

IF $(T(I, N O 4)) 52,51,52$

$51 \operatorname{TEMP}(\mathrm{NO} 4)=\mathrm{PHI}(I, N 04)$

GO TO 53

$52 \operatorname{TEMP}(N 04)=G(N 04)-B E(N 04) * \operatorname{TEMP}(N 04 * 1)$

53 CONTINUE

54 CONTINUE

FOLLOW SIMILIAR PROCEDURE FOR COLUMNS OF MATRIX AS THAT CONSIDERED FOR ROWS

DO $55 I=1, D I M L$

$55 \operatorname{TEMP}(I)=P H I(I, 1)$

INOI $=D I M L-1$

DO $61 \mathrm{~J}=2$, DIMW

DO $57 \mathrm{I}=2$, INOI

IF $(T(I, J)) 56,57,56$

56 CONTINUE

$T I=((2, * T(I, J-1) * T(I, J)) /(T(I, J) * \operatorname{DEL} X(J-1)+T(I, J-1) * \operatorname{DEL} X(J))) / \operatorname{DELX}$ $1(J)$

$T Z=((2, * T(I, J+1) * T(I, J)) /(T(I, J) * \operatorname{DEL} X(J+1)+T(I, J+1) * \operatorname{DEL} X(J))) / D E L X$ $1(\mathrm{~J})$

$T 3=((2, * T(I-1, J) * T(I, J)) /(T(I, J) * D E L Y(I-1)+T(I-1, J) * D E L Y(I))) / D E L Y$ I (I)

$T 4=((2 * T(I+1, J) * T(I, J)) /(T(I, J) * \operatorname{DELY}(I+I)+T(I+1, J) * \operatorname{DELY}(I))) / D E L Y$

$1(I)$

IMK $=$ PARAM $(T I+T 2+T 3+T 4)$

$K=0.0$

$A=T 3$

$\mathrm{CC}=\mathrm{T} 4$

$B=-T 4-T 3-K-I M K$

$W=B-A * B E(I-1)$

$B E(I)=C C / W$

$R R=Q R E$

$R W=0.0$

$R W=R A T E(I, J) /(D E L X(J) * D E L Y(I))$

$D=-T I * P H I(I, J-1)+(T I+T 2-I M K) * P H I(I, J)-T 2 * P H I(I, J+I)+R W-R R$ $G(I)=(D-A * G(I-I)) / W$

57 CONTINUE 
C

NO3 $=0$ IML -2

DO $60 \mathrm{KNO} 4=1, \mathrm{NO} 3$

$\mathrm{NO} 4=\mathrm{DIML}-\mathrm{KNO} 4$

PHI $($ NO $4, J-1)=$ TEMP $($ NO4)

IF $(T(N 04, J)) 59,58,59$

$58 \operatorname{TEMP}(\mathrm{NO4})=$ PHI $(\mathrm{NO} 4, \mathrm{~J})$

GO TO 60

59 TEMP $(N 04)=G(N 04)-B E(N 04) * T E M P(N 04+1)$

IF (DABS (TEMP (NO4) $-P H I(N 04, J)), r, T$. ERR) TEST = I

60 CONTINUE

61 CONTINUE

GO TO 12

C

C

62 FORMAT $(1 H 0,32(13,1 X), 13)$

63 FORMAT $(1 H 1,50 \times, 28 H$ STEADY STATE HEAD CONTOURS 1111$)$

64 FORMAT (IHI,58X,16H HEAD IN FEET//)

65 FORMAT (IHO,I5,11E11.3/(6X,11E11.3))

66 FORMAT $(315,6 F 10.0)$

67 FORMAT $(20 F 4.0)$

68 FORMAT (IHI.61X, IIHRATE MATRIX)

69 FURMAT (IHI,60X, 16 HINPUT PARAMETERS//48H RATE OF VERTICAL RECMARGE

1 OVER AQUIFER IN CFS $=, E 10.3 / 139 H$ NUMBER OF NODES IN A COLUMN OF MA $2 T H I X=, I 4 / / 36 \mathrm{H}$ NUMBER OF NODES IN A ROW OF MATRIX $=, 14 / / 32 \mathrm{H}$ MUMUEN 0 3F ITERATION PARAMETERS $=, 14 / / 28 H$ ERROR CRITEKIA FOR CLOSURE $=0 E I 0.3 /$ $4 / 31$ H MULTIPLIER FOR TRANSMISSIVITY $=0$ E $10.3 / 135 H$ MULTIPLIER FOA RECH 5ARGE-DISCHARGE $=, E 10.31$

70 FORMAT $(1 H I, 64 X, 21$ IHTRANSMISSIVITY MATRIX)

71 FORMAT (1HO,54X,17HTIME STEP NUMBER $=, 110 / 55 X, 27 H S 12 E$ OF TIME STEP IIN YEARS $=, E 10.3 / 55 X, 17 H I$ TERATION NUMBER $=, 1101$

72 FORMAT (4I5)

73 FORMAT (IHI,56X,20HITERATION PARAMETERS///1H,10E12.31)

74 FORMAT (IHO, 39HEXCEEOED PERMITTED NUMBER OF ITERATIONS)

75 FURMAT (16F5.1)

76 FORMAT (IHI,40X,33HMODEL GRID SPACING IN $X$ DIRECTION/ $/ 1 M O, 12 E 10$. 13)1

77 FORMAT (IHO,40X,33HMODEL GRID SPACING IN Y DIRECTION//1IHO,I2EIO. (3))

78 FORMAT $(215,55.0,15)$

79 FORMAT (IHI, $40 X, 40 H S T E A D Y$ STATE WATER QUALITY CONFIGURATION/N

80 FORMAT (IHI, 40X, 22HRECHARGE WATER QUALITY $/ 1)$

81 FORMAT (IHO,25HCAUTION, ANOMALY AT NODE, 213$)$

82 FORMAT (20I4) END 